This is the peer reviewed version of the following article:

Application of Hydrogen Isotopes in the Life Sciences, J. Atzrodt, V. Derdau, W.J. Kerr and M. Reid, Angew. Chem. Int. Ed., 2017, doi: 10.1002/anie.201704146

which has been published in final form at:

http://onlinelibrary.wiley.com/doi/10.1002/anie.201704146/abstract

This article may be used for non-commercial purposes in accordance With Wiley-VCH Terms and Conditions for self-archiving 


\section{Applications of Hydrogen Isotopes} in the Life Sciences

Jens Atzrodt, ${ }^{[a],}$ Volker Derdau, ${ }^{[a], ~ W i l l i a m ~ J . ~ K e r r, ~}$

${ }^{[b]}$ and Marc Reid ${ }^{[b]}$.

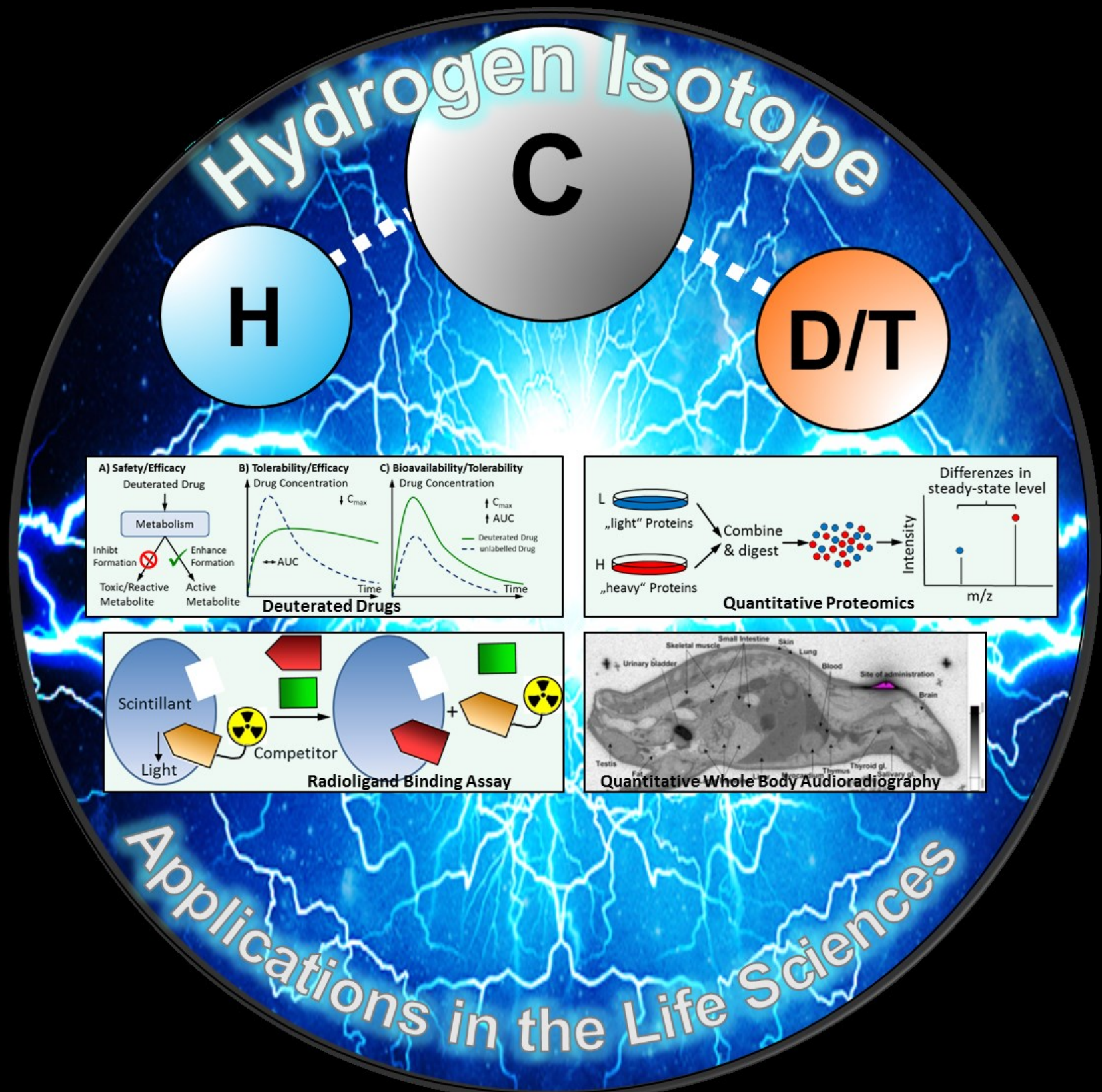


Abstract: Hydrogen isotopes are unique tools for identifying and understanding biological or chemical processes. Hydrogen isotope labeling allows for a traceless and direct incorporation of an additional mass or radioactive tag into an organic molecule with almost no change in its chemical structure, physical properties or biological activity. Using deuterium labeled isotopologues to study the unique mass spectrometric (MS)pattern generated from mixtures of biological relevant molecules drastically simplifies analysis. Such methods are now providing unprecedented levels of insight in a wide and continuously growing range of applications in the life sciences and beyond. Tritium $\left({ }^{3} \mathrm{H}\right)$, in particular, has seen an increased utilization, especially in pharmaceutical drug discovery. The efforts and costs required for the synthesis of labeled compounds are more than compensated for by the enhanced molecular sensitivity for analysis and high reliability of the data obtained. In this review, advances in the applications of hydrogen isotopes in the life sciences are described.

Jens Atzrodt studied chemistry in Jena and obtained his $P h D$ in 1999 with Prof. R. Beckert before joining Aventis Pharma Germany (today Sanofi) as laboratory head and later as section head in the Medicinal Chemistry department (Sanofi) responsible for Isotope Chemistry \& Metabolite Synthesis (ICMS). Today he is the head of the Hub

Management Office at Sanofi Frankfurt. From 2018 he will become President of the International Isotope Society and is presently a member of the advisory board of the Journal of Labeled Compounds and Radiopharmaceuticals (Wiley).
Volker Derdau studied chemistry in Münster and Braunschweig and obtained his PhD in 1999 with Prof. Sabine Laschat. He went for a one year DAAD funded Post-Doc in Prof. Victor Snieckus group (Kingston, Canada) before he started at Aventis Pharma Germany (today Sanofi) as laboratory head. Today he is section head in the Medicinal Chemistry department (Sanofi) responsible for Isotope Chemistry \& Metabolite Synthesis (ICMS), senior lecturer at the University of Applied Sciences (Darmstadt), and European Associate Editor of the Journal of Labeled Compounds and Radiopharmaceuticals (Wiley).

Billy Kerr studied at the University of Strathclyde, gaining his PhD in 1986 with Prof. Peter Pauson and $\mathrm{Dr}$ David Billington. Following postdoctoral research at Brandeis University (Waltham, MA, USA) with Prof. Myron Rosenblum, and Imperial College (London, UK) with Professor Steven Ley, he returned to Strathclyde in 1989 as a Lecturer in Organic Chemistry. Following Senior Lectureship, he was promoted to a Professorial Chair in 2002. He now holds the endowed Chair of 1919 Professor of Organic Chemistry and is Deputy Associate Principal at Strathclyde. He was elected as a Fellow of the Royal Society of Edinburgh (FRSE) in 2014, and in 2015 was the recipient of the Melvin Calvin Award for outstanding contributions to Isotope Chemistry.

Marc Reid earned his PhD (2015) in organic and computational chemistry (w/ Prof. William J. Kerr and Dr Tell Tuttle) from the University of Strathclyde. Recently, he completed postdoctoral studies at the University of Edinburgh (w/ Prof. Guy LloydJones, FRS). In 2016, he was selected for the SciFinder Future Leaders program, and in 2017, he

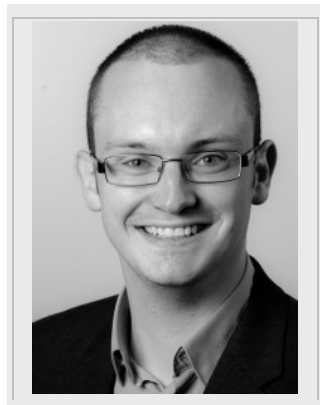
was selected to be among the Young Observers for the IUPAC World Chemistry Leadership Meeting. Marc is currently pursuing independent research at Strathclyde as a Leverhulme Fellow and GSK-funded Early Career Academic, where his research interests include transition metal catalysis, kinetics, and cheminformatics.

[b] Prof Dr W. J. Kerr, Dr M. Reid

Department of Pure and Applied Chemistry, WestCHEM, University of Strathclyde, 295 Cathedral Street,

Glasgow, Scotland, G1 1XL (U.K).

E-mail: w.kerr@strath.ac.uk; marc.reid.100@strath.ac.uk 


\section{Introduction}

For many years, hydrogen isotopes (deuterium and tritium) have been known for their utility in mechanistic, spectrometric, and tracer studies. Moreover, well known applications of hydrogen isotopes exist within almost every sub-discipline in life science, in nuclear science, and beyond. ${ }^{[1]}$ Today, the ability for precise measurement of isotope ratios promotes a dynamic view on biosynthetic pathways, protein turnover, and systems-wide metabolic networks and, thus, has paved the way for a number of scientific breakthroughs in biomedical research. ${ }^{[2]}$ In medicinal chemistry, replacement of hydrogen by deuterium has recently received much attention as a way to alter absorption, distribution, metabolism, and excretion (ADME) properties of drug candidates. ${ }^{[3]}$

Thus, the objective of this review is to provide a brief perspective on the rapidly increasing applications of hydrogen isotopes in life science (Scheme 1).

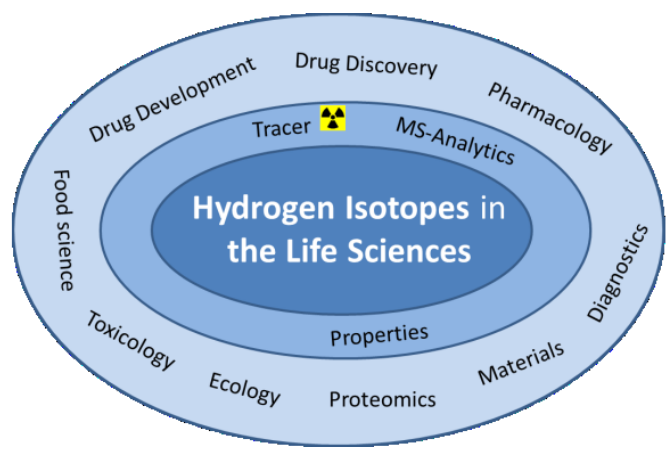

Scheme 1: Applications of hydrogen isotopes in different areas of the Life Sciences

Hydrogen isotopes have many properties of ideal tracer nuclides. Both deuterium and tritium can be detected with very high sensitivity, applying conventional mass spectrometry for the former or radioactivity measurements for the latter. In recent years, the rapid development of high performance mass spectrometry has increased deuterium labeling applications significantly, while tritium continues to play a flagship role in drug discovery. ${ }^{[4]}$ The popularity of hydrogen isotopes in the life sciences stems from their ability to allow for direct incorporation of a unique detection signal into the target molecule without changing its chemical structure, physical properties or biological activity. Consequently, hydrogen isotopes enable the detection and quantification of drug-related material or the discovery of new biological pathways in systems as complex as experimental animals or humans. ${ }^{[5]}$

Deuterium is a stable isotope and thus can be handled under standard wet lab conditions without special permission, handling licenses, or radiation safety measures. This is not the case for tritium. Having said this, emissions are weak enough to make only minimum shielding necessary. Due to the long half-life (12.3 years) of tritium, it is unnecessary to correct for decay during analysis. Thus, once prepared ${ }^{3} \mathrm{H}$-tracer can be stored and used for a long period of time if radiolytical decomposition can be minimised.

Compared to ${ }^{13} \mathrm{C}$ or ${ }^{14} \mathrm{C}$, hydrogen isotope labeling is typically easier, quicker, and much cheaper. ${ }^{[6]}$ On the other hand, it is more difficult to predict the metabolic stability of ${ }^{2} \mathrm{H}$ or ${ }^{3} \mathrm{H}$ labeled compounds. In case of tritium, a reduced biologically tracer stability may result in an in vivo formation of highly toxic ${ }^{3} \mathrm{H}_{2} \mathrm{O}$ which can be distributed throughout the whole body and thus makes radioactivity measurement and quantification more difficult. ${ }^{[7]}$

Incorporation of deuterium or tritium into an organic molecule can be achieved by two principle routes, either by a conventional multistep synthesis or by direct hydrogen isotope exchange (HIE). Depending on the complexity of the chemistry, the chemical structure of the target molecule, and the labeling position, a classical synthesis approach, starting from appropriate commercially available labeled precursors, can be very time and resource consuming. Therefore, methods for fast and convenient late stage introduction of deuterium or tritium into organic molecules were extensively investigated in recent years. The hydrogen isotope exchange $(\mathrm{HIE})^{[8,9]}$ reaction allows for a selective installation of $C-D^{[10]}$ and $C-T^{[11]}$ bonds in the target molecule. Typically heterogeneous metal-catalyzed HIE generally results in relatively unspecific incorporation of numerous deuterium atoms into a molecular substrate. Accordingly, heterogeneous metal-catalyzed $H / D$ exchange is typically the method of choice for preparation of stable isotopically labeled internal standards (SILS) for LC-MS/MS investigations. For SILS applications, the similarities of the mass signals for the unlabeled analyte relative to the signals for the internal standard should be as low as reasonably feasible. As a consequence, heterogeneous exchange methods have been optimized to incorporate $3-5$ deuterium atoms in the case of small molecules without chlorine, bromine, or sulfur-containing functionalities and where the remaining amount of unlabeled $\left(D_{0}\right)$ is negligible. ${ }^{[12]}$

In contrast, homogeneous metal catalyzed HIE methods are typically much more selective incorporating deuterium only at specific positions in the molecule, e.g. next to a directing group. Therefore, these methods are of particular importance for tritium incorporation via $\mathrm{H} / \mathrm{T}$ exchange ${ }^{[11]}$ The breadth of applications and molecular structures that require isotopic labeling ultimately demand a suite of synthetic methods in order to install the isotope in the desired position(s). These methods are highlighted in the connected review " $\mathrm{C}-\mathrm{H}$ Functionalization for Hydrogen Isotope Exchange".[13]

\section{Applications of Deuterium labeled compounds}

Applications of deuterium can be distinguished based on four general concepts: 1 . kinetic and equilibrium isotope effects; 2. the generation of specific MS-patterns (e.g. 1:1 mixtures of labeled and unlabeled analyte); 3 . the utilization for relative quantification based on changes of the ratio of labeled versus unlabeled analyte; and 4 . the use for absolute quantification through internal standardization. The latter three applications are quite similar, as the underlying principle is the generation of a MS detectable mass shift compared to the unlabeled analyte. Consequently, those applications are not restricted to deuterium alone since a similar mass shift could also be achieved by employing other stable isotopes (e.g. ${ }^{13} \mathrm{C},{ }^{15} \mathrm{~N}$, or ${ }^{18} \mathrm{O}$ ). The question whether to use deuterium or another stable isotope label often depends on commercial availability, costs, and the 
synthetic efforts needed for label introduction. Thus, in many cases, deuterium is preferred due to much cheaper precursor costs and the availability of highly efficient $H / D$ exchange labeling approaches. However, for some specific applications (e.g. metabolomics pathway analysis) additional considerations may result in a preference for ${ }^{13} \mathrm{C}$. Whatever the choice of isotope, deuterium applications are typically reported in close conjunction with other stable isotopes, which makes it almost impossible to review deuterium applications alone.

Consequently, this section has been expanded to cover stable isotope applications in general; however, whenever possible, with a particular focus on deuterium.

\subsection{The Kinetic Isotope Effect ${ }^{[14]}$}

Comparing $\mathrm{C}-\mathrm{H}$ and $\mathrm{C}-\mathrm{D}$ bonds, the activation energy for the $\mathrm{C}-\mathrm{D}$ bond is larger. This difference is due to the greater mass of $D$ versus $H$ resulting in a lower vibrational frequency and, thus, a lower zero-point energy (ZPE) of the C-D bond (Scheme 2). [15] The lower energy relative to a $\mathrm{C}-\mathrm{H}$ bond translates to a higher activation energy required to reach the transition state for bond cleavage and, thus, slower reaction rate of deuterated analogues when the rate-determining step involves breaking a covalent $\mathrm{C}-\mathrm{H} / \mathrm{D}$ bond. [16] This effect is known as the primary (kinetic) hydrogen isotope effect and is expressed as the ratio of the reaction rate constants for $\mathrm{C}-\mathrm{H}$ versus $C-D$ bond cleavage, with expected values of $k_{H} / k_{D}>1$ (normal KIE) or $\mathrm{k}_{H} / \mathrm{k}_{\mathrm{D}}<1$ (inverse $\mathrm{KIE}$ ). ${ }^{[17]}$ Substituting hydrogen for deuterium, large KIEs are observed because the relative mass change is great $(100 \%)$, and even greater for tritium; however, KIEs can also occur for other isotopes, such as ${ }^{11} \mathrm{~B}$, ${ }^{13} \mathrm{C},{ }^{15} \mathrm{~N},{ }^{18} \mathrm{O}$, and non heteroatomic bonds (e.g. D-D versus $\mathrm{H}-$ H). ${ }^{[14]}$

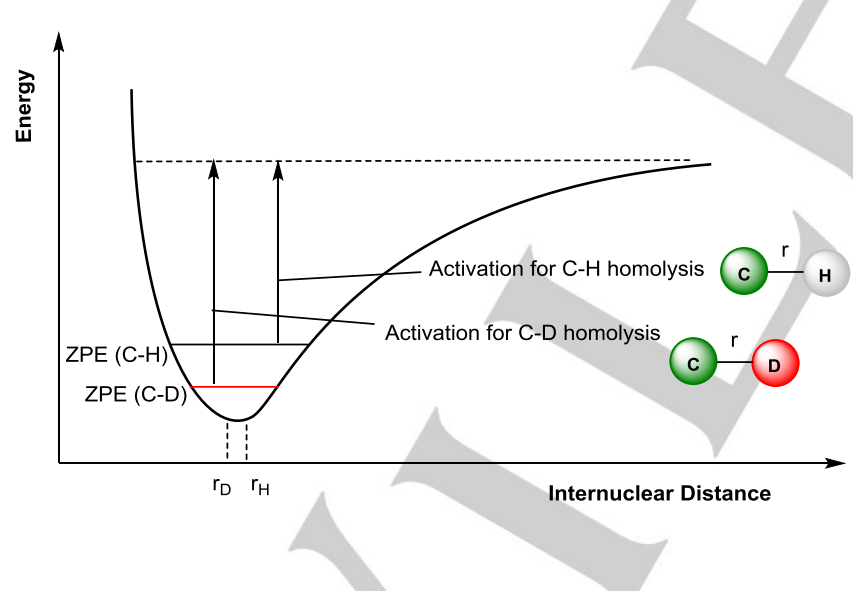

Scheme 2. Origins of the deuterium KIE: the lower zero-point energy (ZPE) results in a higher activation energy for $\mathrm{C}-\mathrm{D}$ bond homolysis.

Besides the semi-classical model, quantum mechanical tunnelling and related kinetic models are also invoked to explain KIEs. ${ }^{[18]}$ The secondary hydrogen isotope effect arises in cases where the $\mathrm{C}-\mathrm{H}$ or $\mathrm{C}-\mathrm{D}$ bond remains intact during the ratelimiting step of the reaction. Secondary KIEs are typically produced due to changes in hybridization (e.g. $\mathrm{sp}^{3}$ to $\mathrm{sp}^{2}$ ), or the involvement of hyperconjugation. Additionally, rates can be also influenced by a slightly reduced steric demand of the $\mathrm{C}-\mathrm{D}$ bond (steric KIE), and the moderately increased ability of the C-D bond to donate electron density by an inductive effect (inductive $\mathrm{KIE}){ }^{[19]}$ The magnitude of secondary isotope effects is much smaller than that of the primary KIEs, and typically in the range of $\approx 1.1-1.2$ (normal) or $\approx 0.8-0.9$ (inverse). The shifts in equilibrium upon isotopic substitution are termed equilibrium isotope effects (EIEs). Reactions may be also affected by the type of solvent used (for example, changing from $\mathrm{H}_{2} \mathrm{O}$ to $\mathrm{D}_{2} \mathrm{O}$ ) if the solvent changes the isotopic composition by $\mathrm{H} / \mathrm{D}$ exchange or the solvation of the activated complex. ${ }^{[20]}$ Today, KIEs can be measured at natural abundance for nearly every type of reaction ${ }^{[21]}$ or, in specific cases, even at the single-molecule level. ${ }^{[22]}$

\subsubsection{Isotope effects for investigation of chemical reaction mechanism}

Kinetic Isotope Effects (KIEs) have been extensively used to study reaction mechanisms by determining rate-limiting and product-determining steps (Scheme 3 ). KIEs are commonly measured using $\mathrm{NMR}^{[23]}$ to detect isotope location and/or GC/MS and $\mathrm{LC} / \mathrm{MS}^{[24]}$ to detect mass changes. As KIEs are typically very sensitive to substrate and transition state structure, these measurements can be used to understand electronic, steric, and related effects. [ $\left.{ }^{25}\right] \mathrm{KIE}$ experiments are often designed and employed to support a computational hypothesis. Thus, the change of the reaction rate following replacement of an atom (typically hydrogen) by its isotope (deuterium) can be compared with the theoretical KIE values to provide essential experimental information on the calculated mechanistic pathway. ${ }^{[26]}$

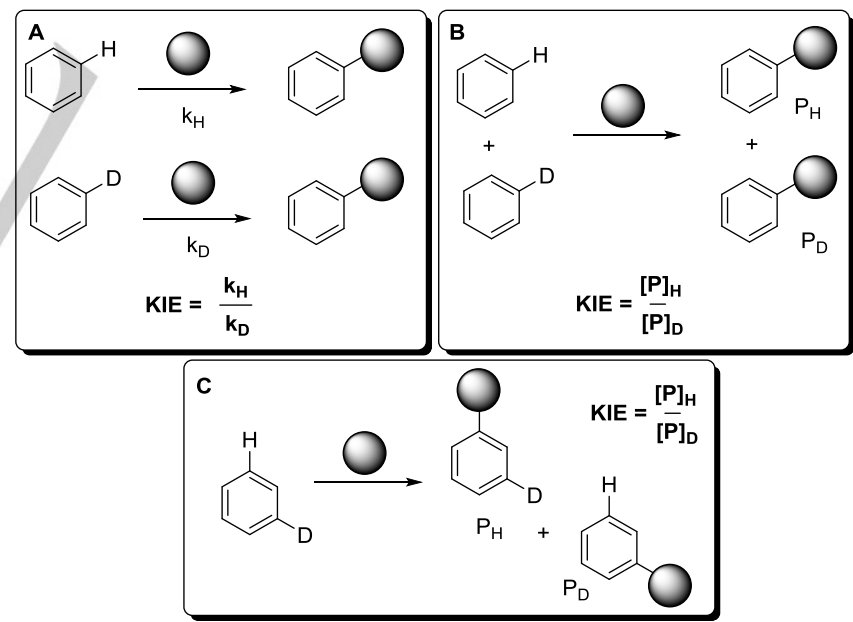

Scheme 3. Complementary deuterium KIE experiments: A) KIE determined from two parallel reactions; B) KIE determined from an intermolecular competition; and C) KIE determined from intramolecular competition. ${ }^{[27]}$

Three different experimental designs are typically used (see Scheme 3). KIE determined from absolute rates of two parallel reactions; KIE determined from an intermolecular competition between deuterium-labeled and unlabeled substrate in the same reaction flask; and $\mathrm{KIE}$ determined from an intramolecular competition, e.g. mediated by placing a directing group (DG) between the $\mathrm{C}-\mathrm{H}$ and $\mathrm{C}-\mathrm{D}$ bonds. Apart from the differences in 
feasibility and precision between the different kinds of experiments, they may also differ in terms of the information they provide. [27] Recent reviews of KIE applications for mechanistic studies include asymmetric, ${ }^{[28]}$ organometallic, ${ }^{[29]}$ and $\mathrm{C}-\mathrm{H}$ bond activation ${ }^{[27]}$ reactions. In addition to mechanistic investigations, KIE experiments have proved to be indispensable tools for understanding tunnelling $\left[\begin{array}{llll} & 30 & \text { and dynamical }\end{array}\right.$ phenomena. ${ }^{[31]}$

In chemical synthesis, KIEs have been utilized only occasionally, e.g. to supress side product formation in cyclization reactions, ${ }^{[32]}$ to facilitate $\mathrm{C}-\mathrm{H}$ functionalization, ${ }^{[33]}$ or to block ortho-lithiation. ${ }^{[34]}$ For example, the route for the total synthesis of (-)-N-methylwelwitindolinone $\mathrm{C}$ isonitrile reported by Garg et al. features the strategic use of a deuterium kinetic isotope effect to improve the efficiency of a late-stage nitrene insertion reaction (scheme 4). ${ }^{[33]}$

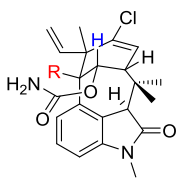

AgOTf, $\mathrm{Phl}(\mathrm{OAc})_{2}$ bathophenanthrolene $\mathrm{MeCN}, 82^{\circ} \mathrm{C}$

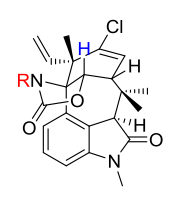

$R=H^{\text {Target Molecule }}$

$\mathrm{R}=\mathrm{H} \quad 33 \%$

$\mathrm{R}=\mathrm{D} \quad 60 \%$
$\mathrm{Cl}$

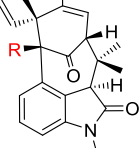

By-product $25 \%$ key bonding event. ${ }^{[44]}$ Accordingly, determining intrinsic isotope effects may require multiple labeling to measure several isotope effects for the same step. ${ }^{[45]}$

\subsubsection{Isotopes applied to improve existing drugs (deuterated drugs)}

Drugs administered to the body typically undergo biphasic metabolic transformation to facilitate elimination by increased water solubility. ${ }^{[46]}$ The major metabolizing enzymes in human are from the cytochrome P450 enzyme family, accounting for $75 \%$ of total drug metabolism and, thus, gaining much attention by the pharmaceutical industry.[ ${ }^{47]}$ Significant KIEs were observed for several P450-catalyzed reactions (Scheme 5), ${ }^{[48]}$ particularly for dealkylations of ethers and amides, while amine $\mathrm{N}$-dealkylation and aromatic hydroxylation reactions typically have low KIEs for mechanistic reasons. ${ }^{[49]}$ Besides P450, other human metabolic enzymes, such as the aldehyde oxidase $(\mathrm{AO})^{[50]}$ and monoamine oxidase (MAO) family, ${ }^{[51]}$ also produce measurable KIEs. This effect is utilized for quantification of native MAO enzyme activities, e.g. in relation to smoking, by a dual tracer approach comparing binding rates of selective PET radiotracers in the presence or absence of an additional deuterium label. ${ }^{[52]}$
Scheme 4. Strategic use of $\mathrm{KIE}$ in total synthesis to facilitate $\mathrm{C}-\mathrm{H}$ functionalization. ${ }^{[33]}$

Apart from their use in relation to the kinetic isotope effect, stable isotopes are also utilized as tracers for mechanistic investigations to determine the nature of intermediates in chemical reactions ${ }^{[35]}$ or to support the elucidation of biosynthetic pathways. ${ }^{[36]}$ The focus in such studies is primarily the location and distribution of the label and, thus, following atoms through the synthetic assembly, e.g. by label-facilitated MS or NMR analysis. ${ }^{[29,37]}$

\subsubsection{Isotope effects for determination of enzyme mechanism}

KIEs also provide a powerful tool to support the study of enzymatic mechanisms ${ }^{[38]}$ and have been extensively utilized to deduce many aspects of enzyme chemistry (e.g. the mechanism of hydrogen transfer, ${ }^{[39]}$ oxygen activation, ${ }^{[40]}$ and acyl transfer reactions) ${ }^{[41]}$ Similar to the experiments outlined in section 2.1.1 for enzymatic mechanisms, KIEs are measured by direct comparison, equilibrium perturbation, or internal competition.

The precision of the internal competition method has made it the most commonly used for investigating small KIEs. ${ }^{[42]} \mathrm{KIEs}$ can provide useful information for all parts of kinetic enzymatic mechanism studies.[ ${ }^{4}{ }_{3}$ ] In addition to the bond cleavage/formation step, enzymatic transformations involve multiple elementary steps, including substrate binding, conformational changes, and product release. Elementary steps that are not rate-limiting may still mask the isotope effect relating to the pertinent bond modification step; this then may result in an observed KIE that appears smaller than the intrinsic KIE for the
Depending on the enzymes involved and, hence, the mechanism of the rate-determining step, another consequence can be a different metabolic turnover of drug molecules when replacing hydrogen for deuterium. ${ }^{[53]}$ Although, in principle, this has been known for many years, ${ }^{[54]}$ the alteration of ADME properties by selective deuterium incorporation has only recently received much attention, ${ }^{[55]}$ largely due to the business model of a number of new companies patenting and developing deuterated versions of existing therapeutic molecules. ${ }^{[56]}$ Associated with this, the question whether a deuterated analogue of a known compound is obvious in light of prior art has been a subject for continuous debate, ${ }^{[57]}$ with a recent tendency toward increased rejection of new patent applications for deuterated drug analogues. ${ }^{[58]}$

The underlying principle in deuterated drugs being assessed as new drugs versus their unlabeled precursors relies on the assumption that specific deuterium labeling may result in potential beneficiary properties. Such properties include reduced systemic clearance and higher systemic exposure, as well as reduced formation of toxic or reactive metabolites, while retaining the potency of the original drug (Scheme 6) ${ }^{[3]}$ 
Consequently, potential drug benefits could include a reduced dosage or dosing regimen, a smaller potential for drug-drug interactions, and a lower incidence of side effects, resulting overall in an improved pharmacokinetic and safety profile, and enhanced effectiveness. However, it has become increasingly clear that prediction of the deuterium effect from in vitro data is difficult and, particularly for Cytochrome P450 (CYP)-mediated metabolism, ${ }^{[59]}$ suppression of one pathway may not result in appreciable alteration of in vivo ADME properties as metabolic switching may promote alternative clearance routes. ${ }^{[60]}$

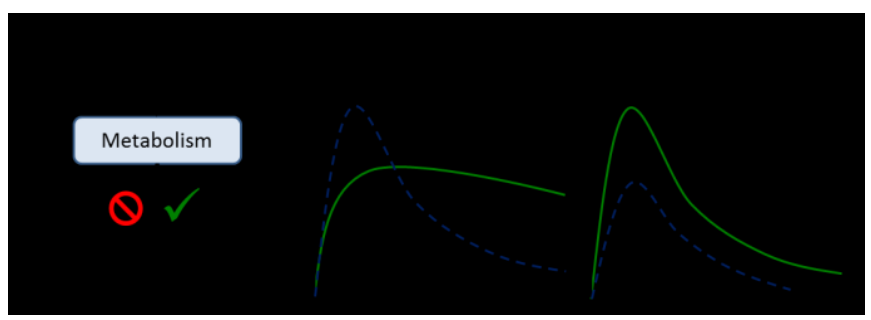

Scheme 6. Potential pharmacological effects of specific drug deuteration: A Metabolic shunting resulting in reduced exposure to undesirable metabolites (e.g. toxic or reactive); B: Reduced systemic clearance resulting in increased half-life; and C: Decreased pre-systemic metabolism resulting in higher bioavailability of unmetabolized drug. ${ }^{[3 a]}$

Significant clinical progress has been made in recent years regarding the use of deuterated drugs. ${ }^{[61]}$ In 2017, the U.S. Food and Drug Administration (FDA) has accepted the New Drug Application (NDA) for SD-809 (now Austedo ${ }^{\circledR}$ ), ${ }^{[62]}$ for the treatment of chorea associated with Huntington disease, based on successful Phase 3 clinical trials. ${ }^{[63]}$ SD-809 shows similar efficacy to tetrabenazine at lower doses and with a longer duration of action; thus, the dosing regimen was reduced from three times to only twice daily. ${ }^{[58]}$<smiles>[2H]C([2H])([2H])C(=O)CCCn1c(=O)c2c(ncn2C)n(C)c1=O</smiles>

CTP-499

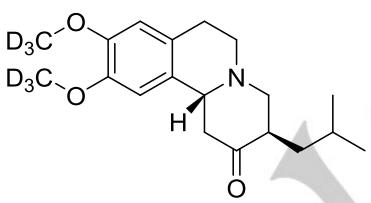

SD-809

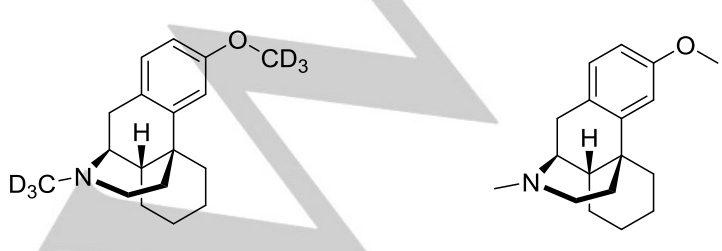

Dextromethorphan- $d_{6}$<smiles>CC(=O)CCCCn1c(=O)c2c(ncn2C)n(C)c1=O</smiles>

Pentoxifylline<smiles>COc1cc2c(cc1OC)[C@@H]1CC(=O)C(CC(C)C)CN1CC2</smiles>

Tetrabenazine (Xenazine)

Dextromethorphan
Scheme 7. Selected deuterated clinical drug development candidates and corresponding unlabeled original drugs.

Other deuterated drugs, such as CTP-499 (deuterated

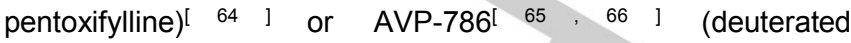
dextromethorphan), are currently in advanced clinical testing ${ }^{[67]}$ or have demonstrated improved in vivo PK properties (Scheme 7). ${ }^{[68]}$

Instead of using deuterium to control metabolism and pharmacokinetic $(\mathrm{PK})$ properties, another approach is Deuterium-Enabled Chiral Switching (DECS), which is employed in order to stabilize and characterize the preferred enantiomers for the racemic active ingredients of marketed drugs, which would otherwise interconvert. ${ }^{[69]}$

\subsubsection{Isotope effects in Toxicology}

Kinetic isotope effects can also be used as a tool to investigate metabolism-mediated target organ toxicities. ${ }^{[70]}$ For example, 1,2-dibromoethane caused greater DNA damage than its deuterium labeled analogue, suggesting that deuterium substitution led to a decrease in metabolism and, thus, a longer half-life of the DNA alkylating species. ${ }^{[71]}$ In a second example, deuterochloroform $\left(\mathrm{CDCl}_{3}\right)$ was reported to be up to $70 \%$ less toxic in rodents than $\mathrm{CHCl}_{3}$ because the decreased metabolic rate results in decreased formation of nephrotoxic phosgene. ${ }^{\text {[2] }}$ Additionally, negative side effects associated with the consumption of alcohol can be diminished because of a significantly reduced rate of absorption and, thus, reduced peak concentration and delayed ingestion observed for deuterated ethanol. ${ }^{[73]}$ Further examples include the application of stable isotope labeled $\mathrm{N}$-methylformamide (NMF) in toxicogenomic studies for identification of potential genomic biomarkers of hepatotoxicity caused by related reactive metabolites (Scheme 8). ${ }^{[4]}$

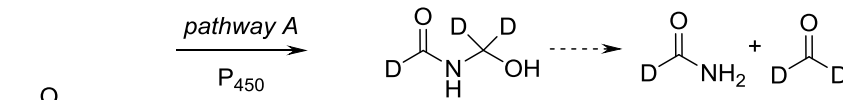

$$
\begin{aligned}
& \text { D }{ }^{-1}{ }^{-} \mathrm{CD}_{3} \quad \mathrm{~N} \text {-(hydroxymethyl)- }
\end{aligned}
$$

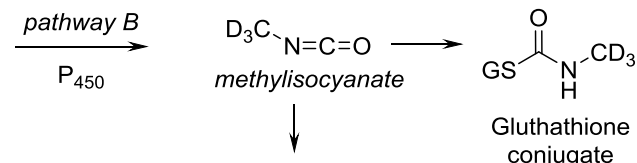

$$
\begin{aligned}
& \mathrm{D}_{3} \mathrm{C}-\mathrm{NH}_{2}+\mathrm{CO}_{2}
\end{aligned}
$$

Scheme 8. Metabolism of NMF leads to the formation of $\mathrm{N}$ (hydroxymethyl)formamide (pathway A) and methylisocyanate (pathway B) The deuterium on the formyl position is lost during the P450-catalyzed oxidation to methylisocyanate. The placement of deuterium(s) at either the formyl or the methyl positions can lead to metabolic switching. For example, deuteriums on the methyl group can lead to greater levels of methylisocyanate formation through pathway $B$ as demonstrated in mice dosed with $d_{3}$ NMF ${ }^{[70,74]}$

\subsubsection{Isotope effects in non-covalent interactions}

In addition to KIE involved in covalent bond forming or cleaving processes, isotope effects on non-covalent interactions 
are also known, and mainly attributed to changes in polarity, polarizability, and molecular volume due to the shorter C-D bond length. ${ }^{[75]}$ Deuteration of hydrocarbons typically results in more polar, less lipophilic molecules, while in presence of heteroatoms (e.g. $\mathrm{N}, \mathrm{O}, \mathrm{S}$ ) the effect strongly depends on the position of deuterium. Although, in the vast majority of cases, unlabeled and deuterium labeled counterparts co-elute in reversed phase chromatography, the slight alteration of lipophilicity may affect retention times and can sometimesresult in resolution of the isotopologues (see Scheme 9). ${ }^{[7]}$ This effect, known as chromatographic isotopic fractionation, has become even more relevant during recent years, due to the highly efficient chromatographic separations obtained by ultra-high performance liquid chromatography (UHPLC) instruments ${ }^{[77]}$ and, accordingly, needs to be kept in mind particularly when using deuterated internal standards, ${ }^{[78]}$ (see section 2.2.1) or within proteomic studies[79] (see section 2.3). Again, under standard LC-MS conditions in drug discovery (1-3 minutes overall elution time) the risk of misinterpreting quantitative analysis remains very small.

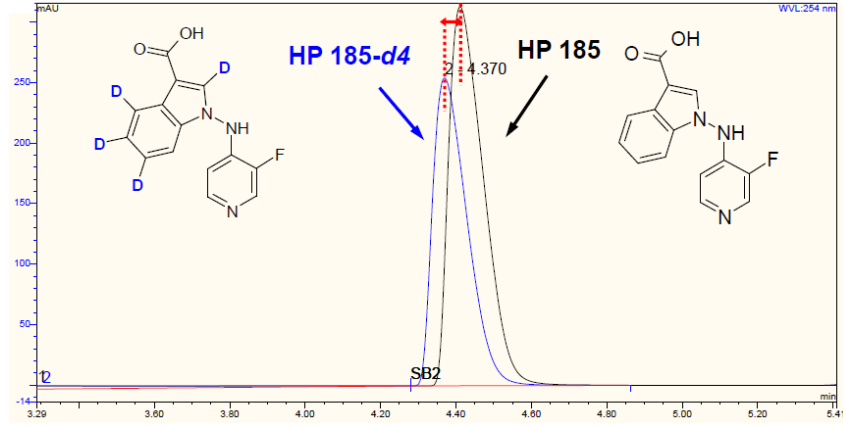

Scheme 9. Chromatographic isotopic fractionation: in rare cases sligh alterations in lipophilicity have the potential to change retention times and can result in resolution in $\mathrm{C} 18$ reversed phase chromatography: Example deuterated and non-deuterated HP185. ${ }^{[80]}$

Generally, the number of deuterium substitutions increases the potential for chromatographic resolution; having stated this, label location, molecule size, molecule structure, retention mechanism, retention times, and mobile phase $\mathrm{pH}$ may also have an influence. ${ }^{[81]}$ Furthermore, binding affinities can also be subject to deuterium isotope effects on van der Waals interactions and, thus, lead to stabilization or destabilization of binding to a ligand depending on the deuterium position. ${ }^{\text {[75, } 82]}$

Selective deuteration can also influence the morphology and phase separation kinetics of polymer blends, ${ }^{[83]}$ and alter the thermal, elastic, ${ }^{[84]}$ and optoelectronic properties ${ }^{[85]}$ of conducting polymers. ${ }^{[86]}$

The deuteration of organic light-emitting diode (OLED) molecules, ${ }^{[87]}$ such as tris-(8-hydroxyquinoline)aluminium ${ }^{[88]}$ or tris-(2-phenylpyridine)iridium, ${ }^{[89]}$ resulted in enhanced highvoltage stability and quantum efficiency compared to the respective protonated OLED devices. Additionally, a strongly enhanced near-IR luminescence and increased lifetime was observed for ytterbium and neodynium cryptates upon deuteration. ${ }^{\left[{ }^{90]}\right.}$ As such, there is particular interest in deuterated molecules for use in OLED devices. ${ }^{[91]}$ Deuterium substitution has been shown to change the superconducting transition temperature (Tc) in organic superconductors due to a reduced lattice volume and internal pressure originating from the smaller zero-point spacing of the C-D bonds. ${ }^{[92]}$ It should also be noted that isotopic substitution can increase the scattering length density (SLD) contrast in neutron scattering measurements. ${ }^{[86]}$ Thus, in combination with selective deuterium labeling, neutron scattering experiments can be used to study deformation mechanisms of polymers ${ }^{[93]}$ and to investigate size, shape, and dynamic interactions of complex biological structures. ${ }^{[94]}$

Introducing deuterium isotope chirality ${ }^{[95]}$ in a monomeric unit can result in a cooperative structural chiral isotope effect, ${ }^{[96]}$ leading to a preference for only one helical conformation of a dynamical racemic polymer and, thus, delivering supramolecular chirality (Scheme 10). ${ }^{[97]}$ This amplification of isotopic chirality, ${ }^{[98]}$ together with an asymmetric autocatalysis, have been discussed as potential pathways to biological homochirality. ${ }^{[99]}$
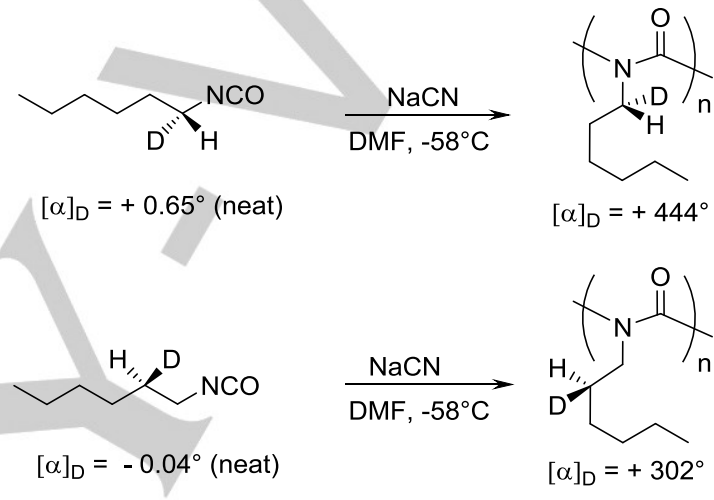

$[\alpha]_{D}=+444^{\circ}(n$-hexane $)$
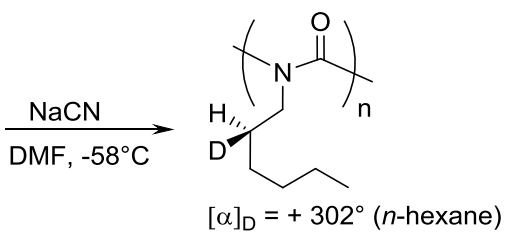

Scheme 10. Structures and changes in optical activities in the conversion of deuterated monomeric isocyanates to the corresponding polyisocyanates. Circular dichroism studies of the two deuterated polymers demonstrate that the source of the chiral optical characteristics arise from the chromophore of the helix and, therefore, arise from a large excess of one helical sense in each polymer. ${ }^{[96 a]}$

Although general isotopic substitution is not expected to change solid state characteristics, for selected compounds isotopic polymorphism and, consequently, a change of crystal structure upon deuterium labeling have been reported. ${ }^{[100]}$ Additionally, the molecular aggregation in the solid state can be sensitive to the use of deuterated solvents during the crystallization process. ${ }^{[101]}$

In supramolecular systems, isotope effects on binding affinities, with enhanced stabilities observed for deuterated guests in self-assembled capsules, ${ }^{[102]}$ could be due to the reduced steric interactions arising from the shorter $\mathrm{C}-\mathrm{D}$ bonds, as opposed to stronger attractive $C D-\pi$ interactions. ${ }^{[103]}$

\subsubsection{Stable isotope fractionation}

The natural abundance of stable isotopes, such as $\mathrm{D}\left({ }^{2} \mathrm{H}\right)$, ${ }^{13} \mathrm{C},{ }^{15} \mathrm{~N}$ and ${ }^{18} \mathrm{O}$, was fixed when the Earth was formed and, on the global scale, has not changed since. ${ }^{[104]}$ However, due to the $\mathrm{KIE}$, subtle variations in the isotopic composition, also known as isotopic fractionation, ${ }^{[105]}$ can result in accumulation of heavier isotopes in the residual substrate fraction of biological, chemical, or physical degradation processes. As a result, the relative abundance measured in different materials can provide 
important environmental information on their origin and history. ${ }^{[106]}$ Accordingly, analysis of naturally abundant stable isotope ratios, e.g. by IRMS (Isotope Ratio MS), ${ }^{107]}$ IRIR (Isotope Ratio IR), ${ }^{[108]}$ or ICP-MS (Inductively Coupled Plasma $M S)^{[109]}$ has been recognized as a powerful tool in forensic science, geochemistry, paleoclimatology, ecology, and physiology. ${ }^{[110]}$ Applications are numerous and include, for example, the origin and/or counterfeit tracing of food, ${ }^{[111]}$ water, ${ }^{[12]}$ pollutants, ${ }^{[113]}$ or pharmaceuticals, ${ }^{[114]}$ and the isotopic characterization of drugs ${ }^{[115]}$ and explosives, ${ }^{[116]}$ as well as the fate assessment of contaminants in soils and aquifers. ${ }^{[117]}$ Due to isotopic fractionation processes, $\mathrm{D} / \mathrm{H}$ ratios of lipids vary substantially with growth conditions and, thus, the resulting patterns hold enormous potential as biogeochemical tracers. ${ }^{[118]}$ Isotope ratio measurement also helps in the reconstruction of entire food webs and energy flows, from basal resources at the bottom to large consumers at the top. ${ }^{[119]}$ Additionally, the method is applied in wildlife forensics to track the origin of migratory species ${ }^{[120]}$ and in crime scene investigations for human provenancing. ${ }^{[121]}$ Furthermore, stable isotope analysis of polar ice cores ${ }^{[122]}$ or tree-rings ${ }^{[123]}$ can provide retrospective insights into climatic and eco-physiological processes. Also, hydrogen isotope ratios in lunar rocks, ${ }^{[124]}$ interplanetary dust particles, ${ }^{[125]}$ meteorites, ${ }^{[126]}$ and comets ${ }^{[127]}$ can provide important information relating to our solar system and the universe. Moreover, stable isotope fractionation is known to occur as part of natural evaporation/condensation cycles (Scheme 11). ${ }^{[129]}$

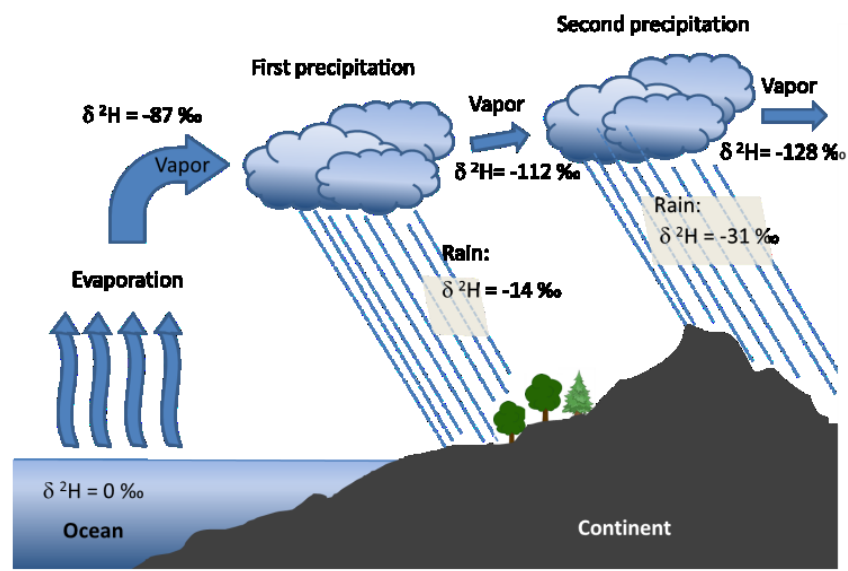

Scheme 11. Stable isotope fractionation occurs naturally through evaporation/condensation. Lighter isotopes preferentially evaporate while heavier isotopes condense preferentially to form precipitation. Thus, water molecules can be traced from their source to a given catchment based on fractionation ratios. ${ }^{[128]}$

\subsection{Stable isotopes in pharmaceutical drug discovery and development}

\subsubsection{Isotope labeled internal MS Standards}

In recent years, liquid chromatography coupled with tandem mass spectrometry detection (LC-MS/MS) has become the most powerful bioanalytical tool for the investigation of samples originating from environmental, animal, and human studies. ${ }^{[129]}$
For a quantitative LC-MS/MS analysis of an analyte in complex matrices (e.g. blood, urine, or bile), internal standards are considered essential. This helps compensate for matrix effects, ${ }^{[130]}$ such as ion suppression, ${ }^{[131]}$ and to account for any other potential variations during sample preparation and chromatography. Stable isotopically labeled internal standards (SILS) are particularly advantageous due to the similarity of the physical and chemical properties of the analyte and its standard. Both can be extracted from biological samples to the same extent and have identical retention times in chromatographic methods and ionization characteristics in the LC/MS but differ on account of their molecular masses. If this mass difference is large enough to avoid cross signal overlapping as a result of the natural isotope pattern, quantitative determination is possible (Scheme 12). The compound of interest is measured relative to the added internal standard by correlating a response ratio with a concentration ratio. ${ }^{[132]}$

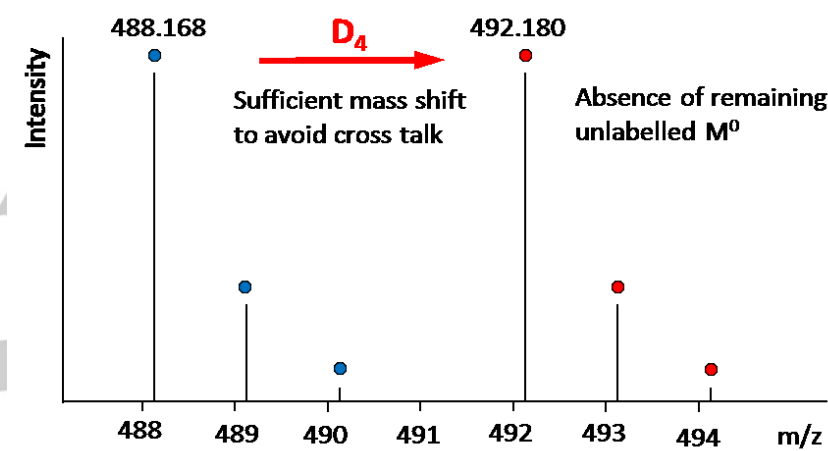

Scheme 12. Stable Isotope labeled internal standards need to have a sufficient mass difference (typically, for small molecules without chlorine, bromine or sulfur-containing functionalities, an incorporation of 3 to 5 deuterium atoms) to avoid cross signal overlapping and negligible remaining MO. [133]

Today, LC-MS/MS based assays are routinely developed for small molecule drug candidates very early in the pharmaceutical development timeline. This helps generate toxico- and pharmacokinetic information on the parent drug ${ }^{[134]}$ and related metabolites ${ }^{[135]}$ from animal and human studies. Stable isotope labeled CYP-specific probes are utilized for in vitro drug-drug interaction studies to facilitate e.g. LC-MS/MS-based high throughput screening of time dependent CYP inhibition for drug candidate profiling. ${ }^{[136]}$ Similarly, stable labeled internal MS standards are also needed to analyse legal or illegal drugs, ${ }^{[137]}$ for anti-doping testing, ${ }^{[138]}$ for human bio-monitoring ${ }^{[139]}$ and for a wide range of environmental contamination testing, such as ecotoxicology and exposure analysis of air ${ }^{140}$ ] and groundwater. ${ }^{[141]}$

Following the strong increase in development of biopharmaceuticals, LC-MS/MS has recently attracted much interest as a viable alternative to the traditional ligand binding assays (LBA) for quantification of proteins. [142 ] Protein bioanalysis by LC-MS/MS offers several advantages over immunoassays, including higher throughput, and enhanced robustness, precision, and accuracy. [143] Due to the incompatibility with molecules larger than approx. $10 \mathrm{KDa}$, 
protein quantification by LC-MS/MS usually includes proteolytic digestion to cleave the protein into a mixture of smaller peptides. ${ }^{[144]}$ One such unit, the so called signature peptide, is then used for quantification along with an appropriate stable labeled internal standard as surrogate for the intact protein. ${ }^{[145]}$ Compared to small molecule analysis, there are more options for internal standardization using either SILS or structural analogues of the intact protein or the signature peptide (Scheme 13). [ $\left.{ }^{146}\right]$ Recently, a stable isotopically labeled universal surrogate peptide for quantification of a wide variety of immunoglobulin $G$ and Fc-fusion proteins has been introduced. ${ }^{[147]}$

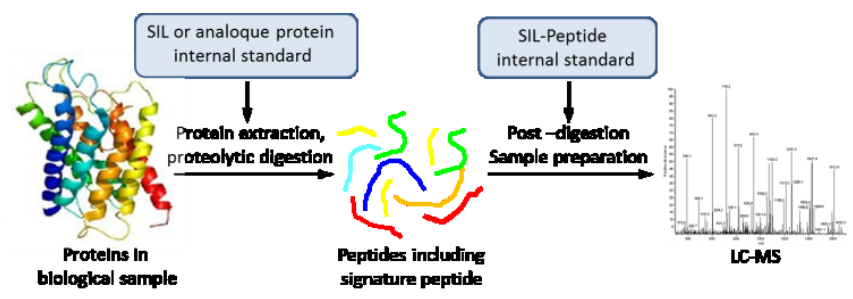

Scheme 13. Bioanalytical work flow and internal standardization for LC-MS quantification of proteins.

Essentially the same strategy, known as AQUA (absolute quantification), is also applied in quantitative proteomics to determine absolute protein concentrations of, for example, unmodified and post-translational modified species. ${ }^{[148]}$

During the synthesis of deuterated internal standards the possibile risk for a H/D back exchange needs to be considered for each reaction step and the conditions optimized accordingly. If HIE methods are applied on the final molecule itself, the exchange needs to be highly efficient to avoid a massspectrometric cross-signal overlap with the remaining $M_{0}$. This potential risk is sometimes mitigated by the use of ${ }^{13} \mathrm{C}$ containing precursors, however connected with a higher costs and longer delivery times.

\subsubsection{Stable isotopes in metabolism studies}

Administration of radiolabeled drugs is essential in order to track the fate of a drug molecule throughout the body and excreta, and to distinguish drug-related material from endogenous components in complex biological mixtures. ${ }^{[149]}$ The evolution of LC/MS technologies has shifted conventional radiolabeled metabolism studies with ${ }^{14} \mathrm{C}$-labelled drug candidates to later stages in drug development. And, besides tritium, stable isotope techniques are increasingly utilized in such biomedical research.[ ${ }^{150}$ ] Compared to radioactivity detection, LC/MS analysis typically requires more intensive method development and validation in order to reach similar limits of quantification (LOQ). Additionally, only radioactivity detection with tritium ensures that unknown active metabolites are not overlooked and therefore tritium is still prefered for in vitro metabolism studies in pharmaceutical drug discovery, (see chapter 3.1).
In cases where special radiation safety laboratories are not available, deuterium can provide useful information. Such applications often employ 1:1 mixtures of an unlabeled analyte with the corresponding stable isotope labeled analogue in order to generate specific MS patterns, with the resulting isotopic doublets providing higher sensitivity and selectivity. For example, 1:1 mixtures of unlabeled and stable isotope labeled compounds can be used for drug metabolite identification and quantification, ${ }^{[151]}$ and to delineate underlying mechanisms and the enzymes involved. ${ }^{[152]}$ Strategic placement of a ${ }^{13} \mathrm{C}$-label in a molecule can help to acquire the critical ${ }^{13} \mathrm{C}-\mathrm{NMR}$ data required to elucidate or confirm the structures of metabolites. ${ }^{[153]}$ In source or online $H / D$ exchange, utilizing deuterium-labeled solvents (such as $D_{2} O$ ), is a technique that may be helpful to distinguish, for example, hydroxylations on carbon from oxidations on heteroatoms by generating a mass shift corresponding to the number of exchangeable protons on

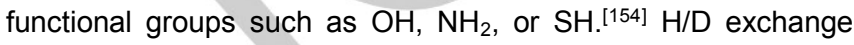
$\mathrm{MS}$ is also emerging as an efficient technique for probing protein conformational dynamics and protein interactions due to ligand binding, protein modification, and protein-protein interactions by monitoring the selective exchange of hydrogen for deuterium along a peptide backbone. ${ }^{[155]}$

Metabolic bio-activation of drugs can also form metabolites that have intrinsic chemical reactivity and, therefore, have the potential to alter biological function and result in serious idiosyncratic adverse reactions. ${ }^{[156]}$ Since direct detection and characterization of reactive metabolites ${ }^{[157]}$ is extremely difficult, several 1:1 mixtures of labeled and unlabeled glutathione $(\mathrm{GSH})^{[158]}$ and glutathione derivatives ${ }^{[159]}$ (Scheme 14) have been introduced as trapping reagents to capture reactive metabolites by formation of stable GSH adducts. ${ }^{[160]}$

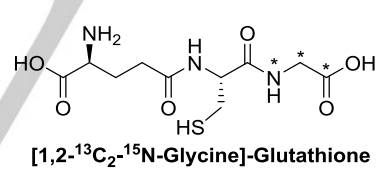<smiles>[2H]C([2H])([2H])OC(=O)CNC(=O)[C@H](CS)NC(=O)CCC(N)C(=O)O</smiles>

Scheme 14. Labeled Glutathione and Gluthathione derivatives for characterization of reactive metabolites.

\subsection{Stable isotopes in mass-spectrometry based quantitative proteomics}

Mass spectrometry-based proteomics has become an indispensible tool in molecular, cellular and chemical biology, encompassing a variety of aspects, including protein primary sequence identification, analysis of post-translational modifications (PTMs), investigation of protein-protein interactions, and protein quantification. ${ }^{[161]}$ Changes in relative abundance of proteins can be measured by quantitative MS analysis of the ratios of stable isotope labeled protein standards and the corresponding unlabeled protein samples. ${ }^{[162]}$ Stable isotope introduction can be achieved by chemical modification or metabolic labeling of a protein. While the latter is limited to living cells, chemical labeling such as the isotope-coded affinity 
reagent tags (ICAT) method[ $\left.{ }^{163}\right]$ can be applied on any proteome, including body fluids and biopsy materials.

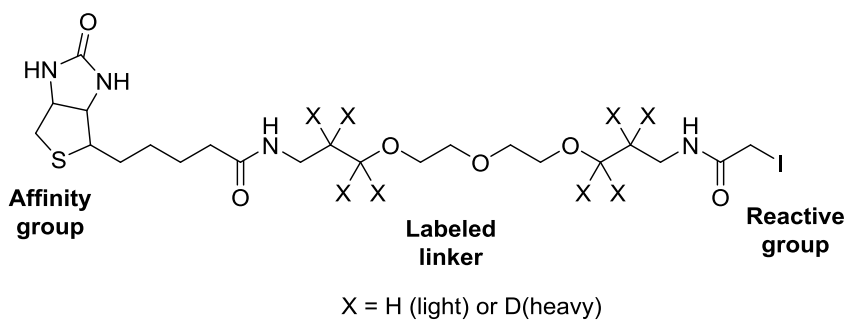

Scheme 15. Structure of ICAT (Isotope-coded affinity tags) reagent comprising a cysteine-reactive group, a linker containing an isotope signature (heavy or light), and a biotin tag for avidin affinity separation. ${ }^{[164]}$

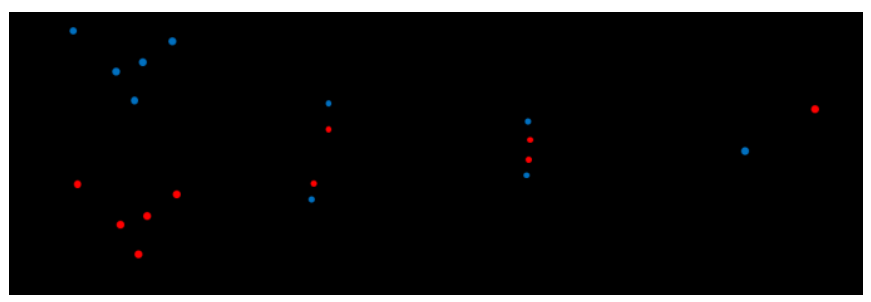

Scheme 16. ICAT workflow for quantifying differential protein expression: two protein samples representing different cell states are labeled with the light or heavy ICAT reagent. The labeled protein mixtures are combined and proteolyzed. Tagged peptides are selectively isolated by avidin affinity chromatography and analyzed by MS. The relative abundance is determined by the ratio of signal intensities of the tagged peptide pairs. $\left[{ }^{164}\right]$

The ICAT reagent consists of three elements: an affinity tag (biotin), a linker containing the stable isotope signatures, and a suitable group to react with cysteine (Scheme 15). ${ }^{[164]}$ In the first step, proteins separately extracted from two different cell states (e.g. sick and healthy) are modified either by unlabeled or by deuterium labeled ICAT. After labeling, the proteins are pooled and digested with trypsin. The resulting modified peptides are isolated by avidin-based affinity chromatography and subsequently analyzed by LC/MS. Relative quantification is determined by the ratio of signal intensities of labeled and unlabeled peptide pairs (Scheme 16). Several variants have been developed in recent years for improvement and extension of the original method. [165] For example, cICAT (cleavable ICAT) ${ }^{[166]}$ was introduced to allow acidic biotin removal prior to LC/MS analysis which enables database searches of free peptides. ICPL (isotope-coded protein labeling) ${ }^{[167]}$ and stable isotope dimethyl labeling ${ }^{[168]}$ were developed for labeling of free amino functions e.g. as in lysine (Scheme 17).

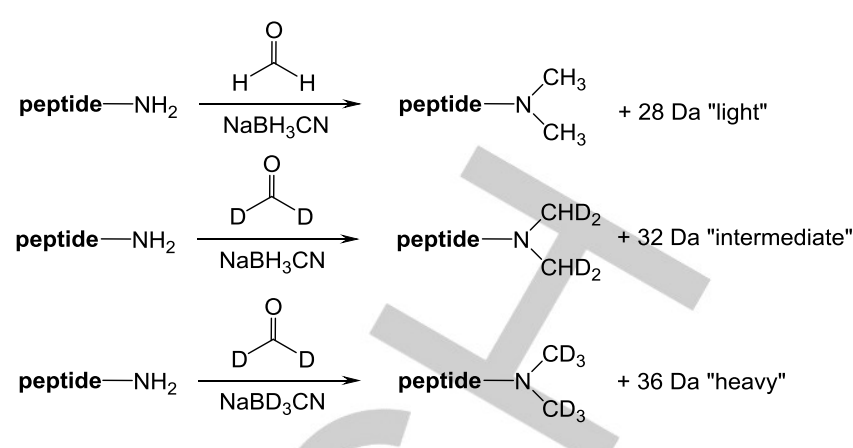

Scheme 17. Labeling schemes of triplex stable isotope dimethyl labeling. ${ }^{[168]}$

Isobaric tags ${ }^{[169]}$ are mass normalized by introduction of an additional mass normalizing region and, thus, produce only a single peak for both healthy and sick samples. However, upon fragmentation, reporter ions with different masses are released due to individual weight differences between signature and mass balancer (Scheme 18) enabling MS characterization of both samples. Two isobaric tag families, TMT (Tandem Mass Tags) ${ }^{[170]}$ and ITRAQ (Isobaric Tags for Relative and Absolute Quantification) [171] are commercially available for multiplex proteomics (Scheme 19), while IPTL (isobaric peptide termini labeling $)^{[172]}$ is currently under development.

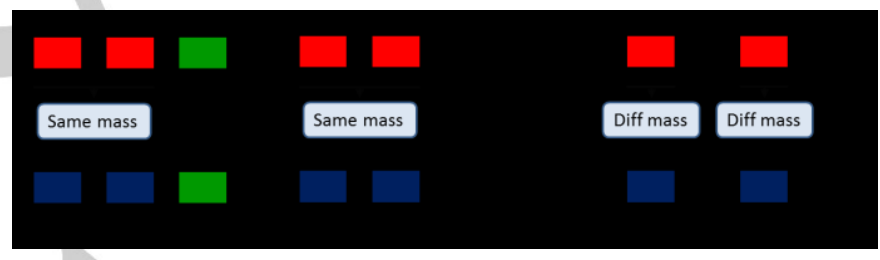

Scheme 18. Isobaric tagging reagents workflow. ${ }^{[175]}$

The stable isotope labeling with amino acids in cell culture (SILAC) concept involves growing two populations of cells but with only one group containing labeled essential amino acids in the medium. ${ }^{[173]}$ Incorporation of the labeled amino acids into the proteome leads to a defined mass shift compared to the unlabeled population. After mixing and extraction, each peptide appears as a pair of labeled and unlabeled units in the MS and, thus, any intensity changes upon different cell treatments also indicate changes in abundance (Scheme 20). ${ }^{174]}$ SILAC is widely used in proteomics for protein expression profiling of normal vs. diseased cells and for identification and quantification of proteins. ${ }^{[175]}$ Recently, SILAC was also used in vivo to label xenograft tumors derived from human colon cells. ${ }^{[176]}$

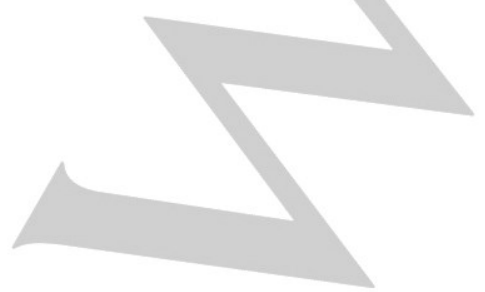




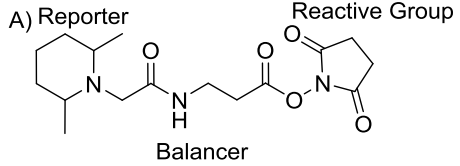

TMT

B)<smiles>CC1CCCC(C)N1C[13C](=O)[13CH2][13CH2][13CH2][13C](=O)ON1C(=O)CCC1=O</smiles>

$126 \mathrm{Da}$<smiles>CC1CCCC(C)N1CC(=O)NCCCC(=O)ON1C(=O)CCC1=O</smiles>

$127 \mathrm{Da}$<smiles>CC1CCCC([13CH3])N1C[13C](=O)[13CH2][13CH2]CC(=O)ON1C(=O)CCC1=O</smiles>

$128 \mathrm{Da}$

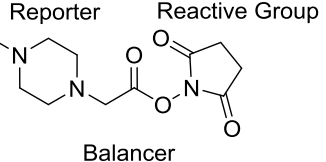

iTRAQ
$129 \mathrm{Da}$

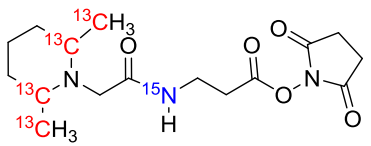

$130 \mathrm{Da}$

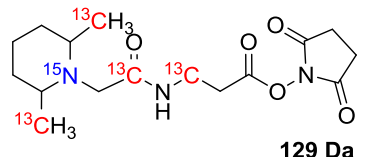

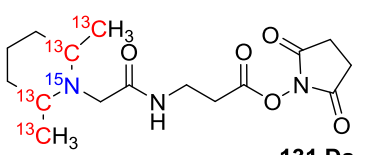

$131 \mathrm{Da}$
TMT sixplex

Scheme 19. A) Structure of TMT (Tandem Mass Tags) and ITRAQ (Isobaric Tags for Relative and Absolute Quantification) reagents; and B) TMTsixplex structure and isotopic masses of reporter ions for the ${ }^{13} \mathrm{C},{ }^{15} \mathrm{~N}$ versions. The mass normalized TMT tag results in six different reporter ions ranging from $126 \mathrm{Da}$ to $131 \mathrm{Da}$ upon fragmentation. ${ }^{[166]}$

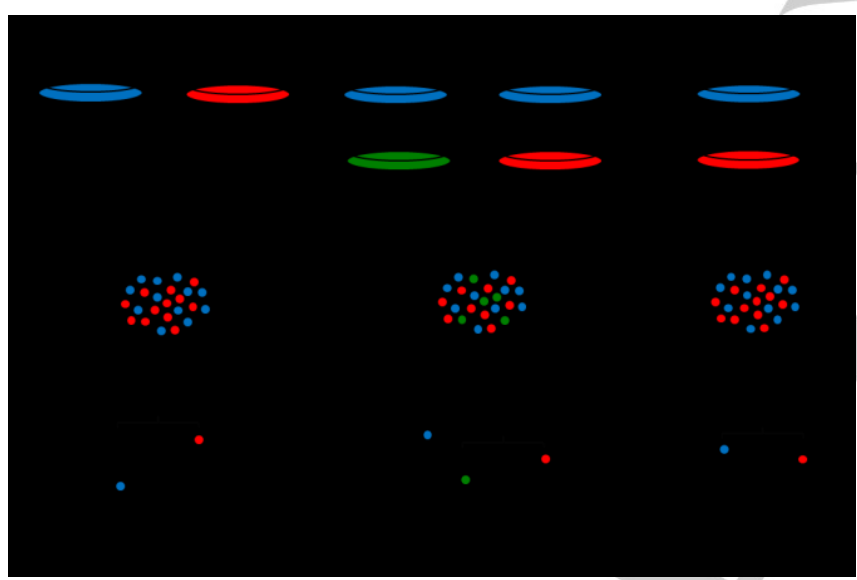

Scheme 20. SILAC workflow: A) Standard SILAC: Cells are cultivated in the presence of either normal or stable isotope labeled amino acids (e.g. Leu-d $\mathrm{d}_{3}$ ), resulting in differentially labeled proteins (heavy or light). After digestion, each peptide appears as a doublet with distinct mass. The ratio of intensities for such peptide pairs accurately reflects the abundance ratio for the corresponding proteins. In the MS spectra, SILAC can be used to quantify differences in steady-state protein levels, e.g. normal vs. deseased. B) pulsed SILAC: Cells cultivated in normal light $(\mathrm{L})$ medium are transfected differently and subsequently pulse-labeled by transferring them to culture medium containing medium-heavy $(\mathrm{M})$ or heavy $(\mathrm{H})$ isotope-labeled amino acids, respectively. PSILAC can be employed to measure differences in protein synthesis upon different treatment. C) dynamic SILAC can reveal protein turnover by measurement of stable isotope incorporation/losses. ${ }^{[165]}$

Stable isotope labeling in mammals (SILAM) was developed to introduce a stable isotope label, typically ${ }^{15} \mathrm{~N}$, comprehensively into an entire rodent by providing food that contains only labeled proteins. ${ }^{[177]}$ Consequently, differences in protein expression between a labeled and an unlabeled rodent can be analyzed by mass spectrometry. SILAM is used to study in vivo pathways or processes that are up- or down-regulated as a function of disease. ${ }^{[178]}$

Recently, organism-wide isotopic labeling was also used to monitor protein turnover rates on thousands of individual proteins in different organs by measuring protein synthesis/degradation ratios through stable isotope tracer incorporation/losses. ${ }^{[179]}$ The methodology, in this context, also named dynamic SILAC (Scheme 20), is fully translatable from model systems to humans. ${ }^{[180]}$ For example, human plasma proteome dynamics [181] was measured following metabolic protein labeling of non-labile covalent $\mathrm{C}-\mathrm{H}$ positions after oral dosing of $\mathrm{D}_{2} \mathrm{O}$; also see section 2.5. ${ }^{[182]}$

\subsection{Stable isotopes in metabolomics}

Beyond the broad utility of hydrogen isotopes in proteomics, the application of stable isotopes has also emerged in the field of metabolomics for system-wide comprehensive analysis of metabolites in various organisms, including microbial, animals, plants, and humans. ${ }^{[183]}{ }^{13} \mathrm{C}$-Based tracers are by far the most commonly applied substrates because of the well-defined carbon transfer in biochemical processes. However, examples of deuterium ${ }^{[184]}$ and ${ }^{15} \mathrm{~N}$ applications ${ }^{[185]}$ in metabolomics also exist. Accordingly, stable isotopes are now facilitating advances in three main areas of metabolomics research: metabolite identification; metabolite quantification; and pathway discovery / flux analysis. ${ }^{[186]}$ Structural identification of unknown metabolites (untargeted metabolomics) can be assisted by feeding the organism of interest with unlabeled and uniformly labeled nutrients, respectively, to generate, after mixing, characteristic LC-MS patterns which can be exploited in data processing steps. ${ }^{[187]}$ Absolute quantification in MS-based metabolomics requires internal standardization in order to avoid matrix effects from co-eluting compounds and, thus, a stable labeled authentic standard of the metabolites (see also section 2.2.2). Alternatively, for spiking individual authentic standards of many hundreds of metabolites, fully labeled metabolomes of specific organisms can be generated when a fully labeled substrate, e.g. ${ }^{13} \mathrm{C}$-glucose, forms the sole carbon source. ${ }^{[188]}$ Recently, in vivo labeling has also been extended to plants; ${ }^{[189]}$ however, typically for more complex organisms, it may be necessary to use a heterologous source of isotope-labeled extract which is then spiked into the study samples. ${ }^{[190]}$

Similar to ICAT in proteomics (see section 2.3), stable isotope-coded derivatization $(I C D)^{[191]}$ has been introduced in metabolomics research to enable non-targeted screening for all metabolites belonging to a specific chemical class. As shown in Scheme 21, several ICD reagents have been developed to support LC/MS analysis by increased sensitivity, ionization efficiency, and chromatographic performance, e.g. DiART (Deuterium Isobaric Amine Reactive Tag), [ 192 ] DMABS (dimethylaminobutyryl succinimide), ${ }^{[193]}$ and TAHS (p-N,N,Ntrimethylammoniumanilyl $N$-hydroxysuccinimidyl carbamate iodide $^{[194]}$ for amino acids. Additionally, methylation is used for modification of amines ${ }^{[195]}$ and glycanes, ${ }^{[196]}$ dansylchloride DNS$\mathrm{Cl}$ for dansylation of amines and phenols, ${ }^{[197]}$ as well as DmPA$\mathrm{Br}$ (p-dimethylaminophenacyl-Br) ${ }^{[198]}$ and CMP (3-carbinol-1methylpyridinium iodide) $)^{[199]}$ for organic acids. For GC/MS-based metabolomics, silylation with MSTFA (N-methyl- $N$ trimethysilyltrifluoroacetamide), $\left.{ }^{200}\right]$ MSTBFA ( $N$-methyl- $N$-tert- 
butyldimethylsilyltrifluoroacetamide), [ 201 ] and methyl chloroformate $(\mathrm{MCF})^{[202]}$ are most frequently used to make analytes less polar and to increase their volatility.

$$
\text { Reporter Balancer Protein reactive }
$$

of depression. ${ }^{[221]}$ After oral dosing of $\mathrm{D}_{2} \mathrm{O}$ to humans, the deuterium equilibrates in water throughout all tissues within $1 \mathrm{~h}$, and when $\mathrm{D}_{2} \mathrm{O}$ administration is discontinued, the label decays with a half-life of body water (approx. 1 week). ${ }^{[222]}$ Labeling of peptides from body water occurs rapidly at the $\alpha$-carbon through transamination and intermediary metabolism (Scheme 22). Subsequently, the deuterium label is incorporated into newly synthesized proteins. ${ }^{[223]}$

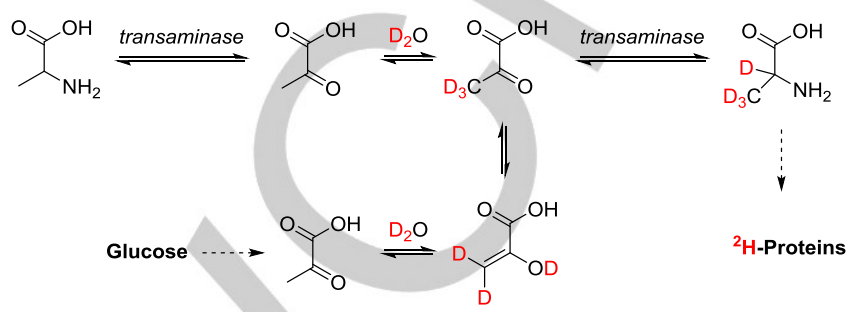

Scheme 22. Transamination process for deuterium labeling of proteins from $\mathrm{D}_{2} \mathrm{O} \cdot{ }^{[224]}$

This approach has been successfully used to monitor skeletal muscle protein synthesis with known perturbations of interest to the field of muscle biology, feeding, and exercise (Scheme 23).[225] Furthermore, heavy water labeling can be extended to investigate lipid ${ }^{[226]}$ and glucose kinetics, ${ }^{[227]}$ as well as total energy expenditure. ${ }^{[228]}$ Recently, experimental protocols for measuring cell proliferation based on deuterium incorporation from $\mathrm{D}_{2} \mathrm{O}$ into the deoxyribose moiety of purine doxyribonucleotides in the DNA of dividing cells have also been described. [229] metabolites, ${ }^{[205]}$ which can be analyzed by NMR to deduce metabolic fluxes. ${ }^{[206]}$ Since the resulting isotopic labeling patterns are a direct consequence of metabolic fluxes, global analysis of labeling patterns would allow for the global detection of metabolic flux changes. ${ }^{[207]}$ In this context, metabolic isotope fingerprinting or footprinting are frequently used terminologies in metabolomics analysis to distinguish intracellular and extracellular metabolite profiling. ${ }^{[208]}$

The determination of metabolic fluxes provides detailed information of cellular physiology. [209 ] Furthermore, the assessment of metabolic flux changes upon a certain perturbation can provide novel information relating to the regulation of pathways ${ }^{[210]}$, their roles in growth, ${ }^{[211]}$ toxicology ${ }^{[212]}$ and disease, ${ }^{[213]}$ and, thus, directly facilitate the improvement of biotechnological processes[ ${ }^{[214]}$ and clinical research.[ $\left.{ }^{215}\right]$ Associated with this, advanced computational tools for data analysis, visualization, and flux models to predict comprehensive metabolic flux maps on a systems scale have been developed; however, the complexity of data handling and analysis still remain challenges to be solved. ${ }^{[216]}$

\subsection{Applications of stable isotopes in clinical pharmacology ${ }^{[217]}$}

Labeling with heavy water $\left(D_{2} O\right)$ has been used safely for decades as a tracer for physiological studies. ${ }^{[218]}$ At lower doses (e.g. $1-2 \% \mathrm{D}$ in body water) $\mathrm{D}_{2} \mathrm{O}$ appears to be well tolerated in humans even for several months, ${ }^{[219]}$ while rodents were kept at $3-20 \% \mathrm{D}$ in body water for months and years without adverse events. ${ }^{[220]}$ However, a recent study demonstrated that the deuterium content in drinking water may influence the incidence

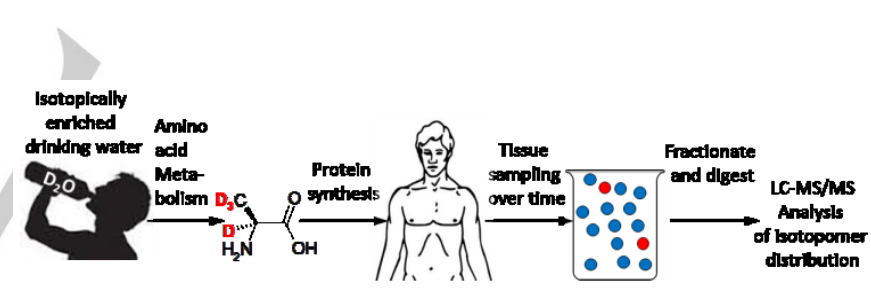

Scheme 23. Experimental workflow for human heavy water labeling study. Isotopically-enriched drinking water was provided to subjects in the study. Endogenous metabolism incorporates deuterium from body water into amino acids and proteins. Samples were collected over time. Proteins from these samples were separated into different fractions using affinity chromatography and then digested for analysis by LC-MS/MS. Subsequent bioinformatic analysis of the peptide isotopomer shift was used to calculate kinetics. ${ }^{[182 \mathrm{a}]}$

Besides $D_{2} O$, [6,6- $\left.D_{2}\right]$ D-Glucose is the most common example of a stable labeled alternative toradioactive analogues, for example, to measure the rate of hepatic glucose production $^{[230]}$ and to assess insulin sensitivity and glucose effectiveness at basal insulin in the stable labeled intravenous glucose tolerance test (IVGTT). ${ }^{[231]}$

The stable isotope labeled kinetic (SILK) protocol is one approach to study the unnatural accumulation of amyloid plaques present in the brains of Alzheimer's patients, as well as the related effect of Alzheimer drugs by monitoring the rates of $\beta$-amyloid peptide production and clearance following protocol, involving oral deuterium oxide administration, administration of $\left[{ }^{13} \mathrm{C}\right] \mathrm{L}-$ leucine. ${ }^{[232]} \mathrm{A}$ dual stable isotope 
coincident with constant infusion of sodium $\left[1-{ }^{13} \mathrm{C}\right]$ acetate, to twelve human subjects, was developed for simultaneous measurement of fractional and absolute synthetic rates of cholesterol. [233]

Stable isotope tracers also enable quantitation of metabolic reactions in vivo. ${ }^{[234]}$ A well- established approach to investigate de novo fatty acid synthesis involves the administration of stable labeled acetate,${ }^{[235]}$ glucose,${ }^{[236]}$ or heavy water ${ }^{[237]}$ For example, the effect of dietary changes on fatty acid metabolism in mice can be measured upon $\mathrm{D}_{2} \mathrm{O}$ labeling. ${ }^{[238]}$ Another strategy involves human administration of a deuterium or ${ }^{13} \mathrm{C}$-labeled fatty acid precusor to study, for example, the effect of smoking ${ }^{[239]}$ or diet ${ }^{[240]}$ on fatty acid metabolism, or to elucidate postprandial fat disposition. ${ }^{[24]}$ Similar approaches with stable labeled fatty acids, glucose, or $\mathrm{D}_{2} \mathrm{O}$ as precursor ${ }^{[242]}$ can be used for dynamic lipidomics, ${ }^{[243]}$ for example, to investigate the regulation of surfactant phospholipid synthesis in human volunteers $^{[244]}$ or to assay [U-13C] palmitate incorporation into ceramides following muscle biopsy. ${ }^{[245]} \mathrm{A}$ more selective and, thus, most frequently applied strategy to investigate phospholipid metabolism in vivo is the introduction of stable labeled head groups into glycerophospholipid by employing $D_{9}$ choline and/or $\mathrm{D}_{4}$-ethanolamine. ${ }^{[246]}$

Another important field where stable isotope approaches are applied in a clinical domain are within one-period, one sequence, crossover study designs for determination of bioavailability, which is the fraction of an administered drug reaching systemic circulation. ${ }^{247]}$ Relative bioavailability is used to compare different formulations of the same compound (e.g. capsule vs. tablet) ${ }^{[248]}$ or to compare a generic version with the original drug. [249] Absolute bioavailability is determined by comparing the blood (plasma) concentration-time-curves (usually as "area under the curve") following extravascular drug and concomitant intravenous stable labeled tracer administration (Scheme 24). ${ }^{[250]}$ With the sensitivity improvements of newer mass spectrometry instrumentation into the pico-molar or even femto-molar range, stable isotope i.v. microdosing ${ }^{[251]}$ has been introduced recently for absolute bioavailability determination. ${ }^{[252]}$ This developed method has the potential for considerable cost and time savings due to reduced safety package requirements, $\left[{ }^{253}\right]$ the avoidance of radioactive ${ }^{14} \mathrm{C}$-tracer administration followed by expensive AMS (Accelerated Mass spectrometry) analysis, ${ }^{[254]}$ and the possibility to combine absolute bioavailability determination in a double-tracer design with conventional radiolabeled human ADME assessment in the same study. ${ }^{[255]}$

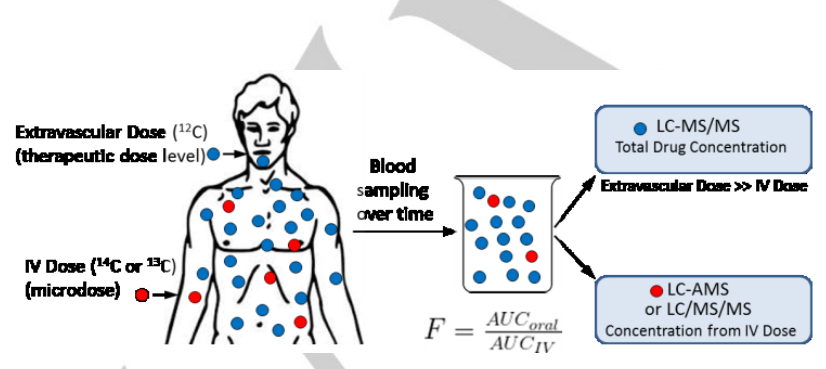

Scheme 24. Microdose Study for determination of absolute bioavailability using either $\mathrm{a}{ }^{14} \mathrm{C}$ or ${ }^{13} \mathrm{C}$ IV microdose.

\subsection{Stable isotopes in diagnostics ${ }^{[256]}$}

Stable isotopes have also advanced the field of diagnostic clinical breath tests for indirect, non-invasive assessment of several pathophysiological metabolic processes. [ ${ }^{[} 257$ ] Replacement of radioactive ${ }^{14} \mathrm{C}$ was an important aspect of research in past years in order to reduce the exposure burden for patients and to enable pediatric applications. The principle of breath tests relies on the concept that the metabolized substrate leads to the production of gases (e.g. $\mathrm{CO}_{2}$ ) excreted in expired air, indicating significant changes in metabolism due to a specific disease or the lack of a specific enzyme. ${ }^{[258]}{ }^{13} \mathrm{C}$-breath tests involve the ingestion of specific ${ }^{13} \mathrm{C}$-labeled substrates, followed by the collection of serial breath samples for analysis of ${ }^{13} \mathrm{CO}_{2}$ enrichment by high resolution isotope ratio mass spectrometers (IRMS) or non-dispersive isotope selective infrared spectrometers (NDIRS). ${ }^{[259]}$ Possibly the most well known, best standardised, and most widely used breath test is the ${ }^{13} \mathrm{C}$-urea breath test detecting gastric Helicobacter pylori infection (Scheme 25). ${ }^{[260]}$ Another important field of clinical ${ }^{13} \mathrm{C}$-breath test application is the assessment of gastric emptying kinetics in response to meals labeled with ${ }^{13} \mathrm{C}$-acetate or ${ }^{13} \mathrm{C}$-octanoic acid. ${ }^{[261]}$ Other breath tests have been developed for diagnosis of exocrine pancreatic insufficiency, ${ }^{[262]}$ for evaluation of dynamic liver function ${ }^{[263]}$ and for assessment of intestinal absorption and transport functions ${ }^{[264]}$ under physiological and pathological conditions.

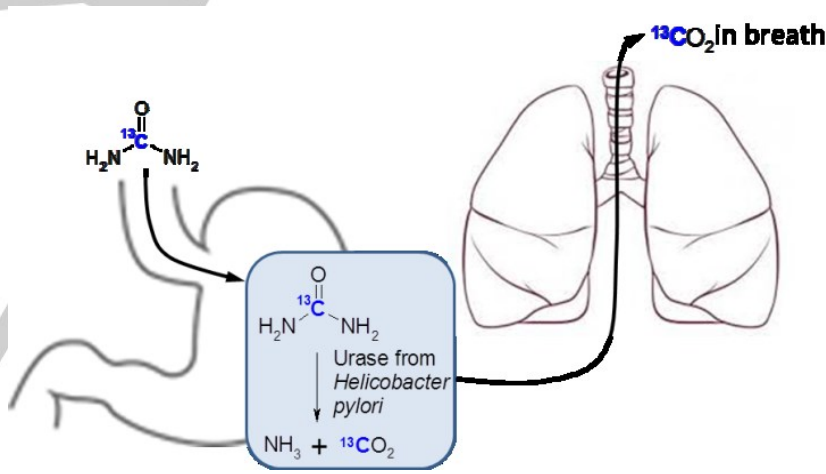

Scheme 25. The urea breath test is a diagnostic test for identification of infections by Helicobacter pylori. This spiral bacterium can cause inflammation, gastric ulcer, and peptic ulcer disease. The test is based on the ability of $H$. pylori to convert urea to ammonia and carbon dioxide. Patients swallow a capsule with ${ }^{13} \mathrm{C}$-labeled urea. Detection of ${ }^{13} \mathrm{C}$-labeled carbon dioxide in exhaled breath indicates that the urea was metabolized and, hence, that $H$. pylori bacteria are present in the stomach. ${ }^{[260]}$

\subsection{Stable isotopes in microbial ecology}

Compound specific isotope analysis $(\mathrm{CSIA})^{[265]}$ is an analytical method to gain information on, for example, contaminant sources and extent of degradation, by measuring the ratios of naturally occurring stable isotopes in environmental samples. The method relies on isotopic fractionation (see section 2.1.6) and bears the potential to delineate differences in degradation mechanism, e.g. aerobic versus anaerobic, or abiotic versus biotic. ${ }^{[266]}$ In contrast, stable isotope probing (SIP) involves incorporation of stable isotope labeled growth substrates into cellular biomarkers that can be used to identify microorganisms assimilating those substrates.[ ${ }^{267]}$ SIP is 
performed by adding isotopically-labeled substrates (typically ${ }^{13} \mathrm{C}^{[268]}$ but with ${ }^{15} \mathrm{~N}^{[269]}$ and $\mathrm{D}^{[270]}$ also being employed) to an environmental sample and then analysing the resulting isotopelabeled biomarkers in the target organisms (Scheme 26). Labeled biomarkers, such as DNA or rRNA, can be recovered by density gradient centrifugation. Subsequently, metagenomic analysis can be performed in order to identify the labeled populations. [ 271 ] This approach has been applied to phospholipid-derived fatty acids (PLFA-SIP) ${ }^{[272]}$, nucleic acids (DNA-SIP ${ }^{273]}$ and RNA-SIP ${ }^{274]}$; (Scheme 26) and proteins (protein-SIP). ${ }^{[275]}$

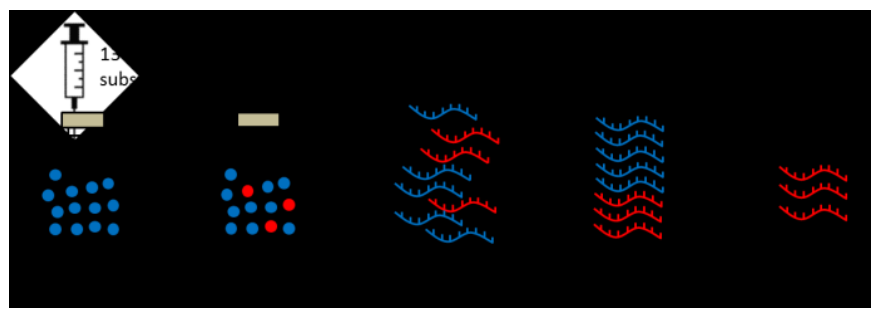

Scheme 26. Principle of Stable Isotope Probing (RNA-SIP): SIP is based on the incorporation of a ${ }^{13} \mathrm{C}$-labeled substrate into cellular biomarkers, such as nucleic acids, separation of labeled from unlabeled nucleic acids by density gradient centrifugation, and molecular identification of active populations carrying labeled nucleic acid.

\section{Applications of Tritium labeled compounds}

Tritium $\left({ }^{3} \mathrm{H}\right)$ is the radioactive isotope of hydrogen. It decays with a half-life of 12.32 years to Helium $\left({ }^{3} \mathrm{He}\right)$ by emission of beta particles with a mean energy of $5.7 \mathrm{keV} .{ }^{[276]}$ The range of the emitted soft $\beta$-particles is about $6.0 \mathrm{~mm}$ in air and $0 \mathrm{~mm}$ in solid medium and, thus, they are incapable of passing through human skin. The emission is sufficiently energetic to make measurement by liquid scintillation counting fairly simple, but weak enough to make shielding unnecessary. In consequence, ${ }^{3} \mathrm{H}$-labeled compounds can be safely handled in standard glass vessels and conventional lab equipment if reasonable radiation safety precautions are taken. Because of these favourable properties, tritium is widely used as a radioactive tracer element in biological research. ${ }^{[277]}$ Another important advantage is the high specific activity of $28.8 \mathrm{Ci} / \mathrm{mmol}$ of tritium, which is approximately 500 times greater than that achievable with a single carbon-14 label $(62.4 \mathrm{mCi} / \mathrm{mmol})$. This property makes tritium irreplaceable for the labeling of large molecules, particularly biomolecules such as peptides, proteins, oligonucleotides, and antibodies. ${ }^{[278]}$ Noteworthy the kinetic isotope effect of tritium is significantly higher compared to deuterium.

The typical sources for the tritium label are tritium gas, other tritiated reagents, and, in some instances, tritium water. Labeling methods have to be compatible with specific requirements for tritium chemistry. In particular, the standard very small scale of operation requires special preparative techniques, operator training, and elaboration methods. ${ }^{[6]}$ Typically, reactions are conducted at reduced pressure ( $<1$ bar) using modern stainless steel manifold systems allowing for the safe handling and storage of tritium gas. ${ }^{[279]}$ Traditional approaches, such as double bond reduction, hydride reduction, and tritium-halogen exchange require upfront precursor syntheses. ${ }^{[280]}$ Alternatively, hydrogen exchange labeling can provide a highly cost- and time efficient method if carried out directly on the target molecule itself. [811]

Today, $\mathrm{H} / \mathrm{T}$ exchange is extensively applied and the very high selectivity and efficiency of new homogeneous metalcatalyzed exchange methods enables specific tritium introduction into biologically- and chemically-stable positions. Consequently, new hydrogen exchange methods have delivered processes to overcome the stability issues associated with earlier chemistry limitations, which had often previously created a rather conservative attitude towards the use of tritium-labeled compounds. ${ }^{[281]}$

\subsection{Tritium in drug discovery \& development}

Tritium facilitates radioligand binding assays which are widely used to characterize receptors, to study receptor dynamics and localization, to identify novel chemical structures that interact with receptors, and to define ligand activity and selectivity in normal and diseased tissues. ${ }^{[282]}$ The selection of the radioligand is based on stability, selectivity, and a high specific activity in the range of $50-100 \mathrm{Ci} / \mathrm{mmol}$, and, thus, typically requires introduction of 2-4 tritium atoms. Additionally, radioligands should have a high affinity and low non-specific binding.

Receptor affinity and density can be readily determined by saturation experiments measuring the dissociation constant and number of specific binding sites for the radioligand at equilibrium. [283] This information can be further used in a competition assay to determine the ability of unlabeled test compounds to displace the radioligand from the same receptor binding site. If conducted at different substrate concentrations, the $\mathrm{IC}_{50}$-value (analyte concentration displacing $50 \%$ of the bound radioligand) can be determined. Finally, kinetic experiments allow the association $\left(\mathrm{k}_{\mathrm{on}}\right)$ and dissociation $\left(\mathrm{k}_{\text {off }}\right)$ rate constants to be determined. ${ }^{[284]} \mathrm{A}$ disadvantage of conventional heterogeneous radioligand binding assays with membrane-bound receptors is the need to separate free from bound ligand, which make these assays labour-intensive and relatively slow.

Alternatively, homogeneous scintillation proximity assays (SPA) have been developed where the receptor is immobilized on the surface of a solid scintillant beat (Scheme 27). ${ }^{[285]}$ As the $\beta$-particle emitted from tritium travels only over a limited distance of $<8 \mu \mathrm{m}$ in aqueous media, only the bound radioligand is in close enough proximity to activate the scintillant causing light emission and, thus, enables direct measurement without the need for separation. [286] SPA is an excellent tool in highthroughput inhibitor screening ${ }^{[287]}$ and was also successfully used for functional characterization of different transporter proteins. ${ }^{[288]}$ Commercially available FlashPlates rely on the same principle but with the receptor now being immobilized at the surface of scintillant coated microtiter plates. ${ }^{[289]}$ 


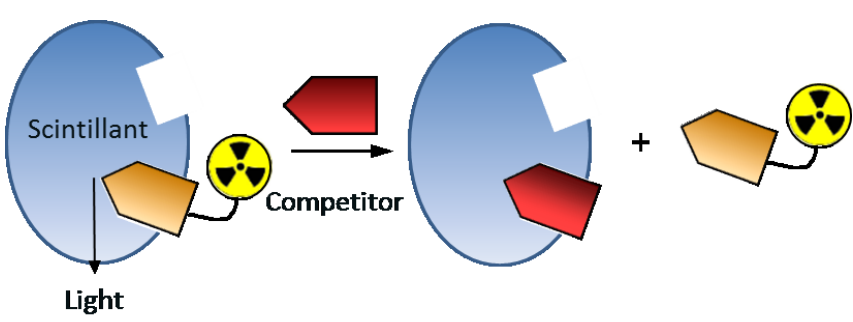

Scheme 27. The scintillation proximity assay is based on the emission of light as a result of an energy transfer from the radioactive ligand to the scintillant beat, containing a scintillant. The emission of light only proceeds if the labeled ligand and receptor are in close proximity, otherwise, the energy of the radioactive ligand is absorbed by the buffer.

Tritium labeled analogues are considered most convenient for in vitro characterization of positron emission tomography (PET) radioligands to determine binding selectivity and kinetics since, for practical reasons, this type of experiment requires isotopes with a longer half life. ${ }^{[290]}$ PET tracers are increasingly utilized as imaging or diagnostic tools, however they are also used for in vivo determination of receptor occupancy by displacement with a therapeutic drug candidate. ${ }^{[291]}$ Alternatively, tritium-labeled comparator compounds can be useful to study or confirm a postulated mechanism of action for the drug or drug analogues. ${ }^{[292]}$ Tritium-labeled cholesterol amphiphile probes have been designed for cell membrane anchoring and imaging of membrane-associated lipoproteins. ${ }^{[293]}$ Additionally, proteolytic degradation, and protein aggregation and turnover can be determined following, for example, metabolic labeling of cellular proteins by substituting one amino acid by its ${ }^{3} \mathrm{H}$-labeled analogue in the culture medium. ${ }^{[294]}$ Sometimes, tritium labeling of enantiomers is used to differentiate chiral from non-chiral processes, for example, as associated with the binding affinities of enantiomers or stereoselective ADME properties. ${ }^{\text {[295] }}$

New drug candidates are routinely tested for their potential to inhibit the uptake of specific tritiated probe substrates mediated by transporter proteins known to play an important role in drug disposition, drug-drug-interaction, and drug toxicity. ${ }^{[296]}$ For example, $\left[{ }^{3} \mathrm{H}\right]$-digoxin has been used to investigate $\mathrm{P}$-gp ( $\mathrm{P}$ glycoprotein) mediated transport, $\left[{ }^{3} \mathrm{H}\right]$-estradiol-17 $\beta$-glucuronide for OATP1B1 (organic anion transporter proteins), and $\left[{ }^{3} \mathrm{H}\right]-$ estrone-3-sulfate for BCRP (breast cancer resistance protein). ${ }^{[297]}$

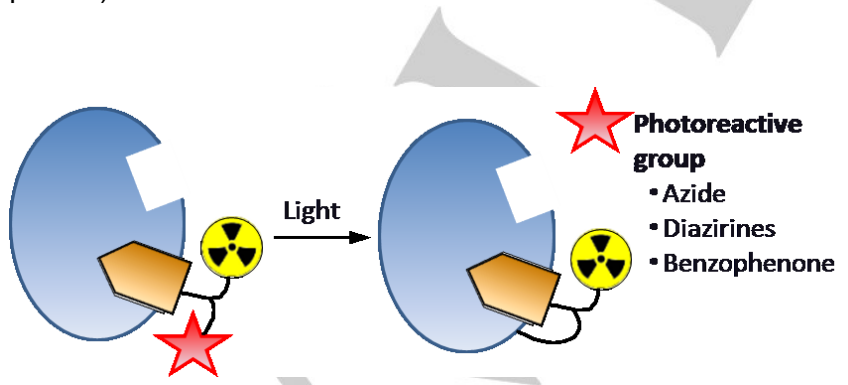

Scheme 28. Photoaffinity labeling. The ligand specifically binds to the active site of the target molecule. Upon light activation a photo reactive group (e.g. arylazides, diazirines, or benzophenones) forms a covalent bond to the target. Subsequently, a reporter tag (typically a radiolabel, a fluorescence dye, or affinity tag) enables isolation/detection of the resulting probe-protein adduct.
Photoaffinity labeling (PAL) is another powerful biochemical technique for the investigation of ligand-protein interactions frequently probed in drug discovery to isolate and identify unknown molecular targets, to study off-target interactions, and for structural elucidation of binding sites. ${ }^{[298]}$ The method is used to investigate plasma proteins ${ }^{[299]}$ and lipidic biomembranes, ${ }^{[300]}$ and can also be used for activity-based proteomics ${ }^{[301]}$ to study enzyme activities and protein complexes. Photoaffinity probes typically involve three functionalities: 1 . a ligand (affinity unit) for reversible and specific binding to the active site of the target macromolecule; 2. a photo reactive group (e.g. arylazides, diazirines, or benzophenones) for covalent target binding upon light activation and generation of highly reactive species; and 3. a reporter tag (typically a radiolabel, a fluorescence dye, or an affinity tag, such as biotin) for isolation/detection of the resulting probe-protein adducts (Scheme 28). ${ }^{[302]}$ In contrast to all other identification tags, a tritium label can be introduced without altering the chemical structure of the ligand and, thus, preserves the affinity towards a target receptor. ${ }^{[303]}$ Additionally, radiolabels can be easily measured with high sensitivity and low background interference and can also be used for in vivo activity assessment in living cells. However, radiolabels provide no direct means for isolation and identification of labeled proteins and, therefore, this approach is mainly used for profiling of known receptors. For target identification, affinity tags (e.g. biotin and short peptide sequences) allow for easier enrichment and detection of labeled proteins using tag specific antibodies. Having stated this, the bulky affinity moiety is not cell permeable and may cause potential steric interference. These disadvantages have been addressed recently by introducing a two-step tandem photoaffinity labeling/biorthogonal conjugation strategy. [ 304 ] Following covalent bond formation via photo-irradiation (step 1), a post-labeling biorthogonal conjugation (step 2) was used to introduce bulky reporter tags, typically via a Click reaction through a terminal alkyne and aliphatic azides. In efforts to capture low affinity or low abundant proteins, isotope-coded photoaffinity probes combining fluorous or fluorogenic tags for enrichment with stable isotopes have been developed recently (Scheme 29). ${ }^{[305]}$ In this approach cells are treated with equal amounts of unlabeled and stable labeled probes separately to generate cross-linked products with a characteristic MS pattern upon mixing and proteolytic digestion ${ }^{[306]}$ (similar to ICAT, see section 2.3).<smiles></smiles>

IsoFT<smiles>[R5]CCC1(c2c([X])c([X])c(COC(=O)ON3C(=O)CCC3=O)c([X])c2[X])N=N1</smiles>

Scheme 29. Isotope-coded fluorescent tag (IsoFT) and isotope-coded fluorous photoaffinity labeling reagents. ${ }^{[305]}$ 
As it is generally believed that only unbound drug (free fraction of a drug) can interact with the target receptor exerting a pharmacological effect, besides receptor binding, another important PK/PD parameter that can impact the efficiency of a drug is plasma protein binding (PPB). [ 307 ] Interspecies differences in PPB may affect drug-safety margins and, thus, a careful assessment of unbound drug concentration in human and animal plasma is requested by authorities before initiating clinical trials (Scheme 30). Typically, techniques such as equilibrium dialysis, ultrafiltration, and ultracentrifugation, relying on unlabeled

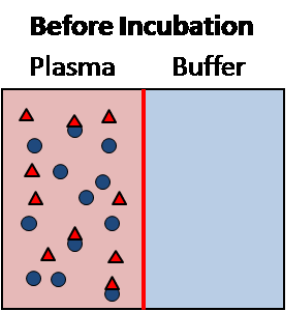

Membrane

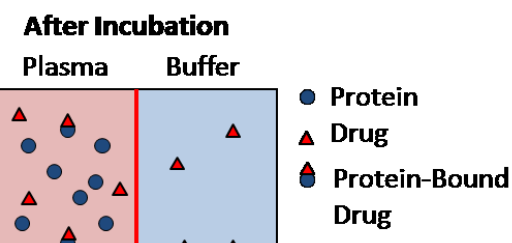

Scheme 30. Plasma Protein Binding (PPB) assay based on equilibrium dialysis. After incubation, both the plasma and buffer samples are analyzed for drug concentration (LC-MS/MS or radioactivity). material, are used in drug discovery to guide structural design and lead selection. ${ }^{\left[{ }^{[08]}\right.}$ However, in preclinical drug development radiolabeled drugs are often preferred because of the higher accuracy of the measurement, particularly in the case of very high plasma protein binding. ${ }^{[309]}$

As stated in section 2.2.2, in order to allowing the effective tracking of a drug molecule throughout a complete physiological system, the use of radiolabeled drugs allows both qualitative and quantitative assessment of drug distribution, metabolism, and excretion (ADME) to be assessed. [310]

Either ${ }^{14} \mathrm{C}$ or ${ }^{3} \mathrm{H}$ are used as radioactive isotopes in such ADME studies, with a general preference for ${ }^{3} \mathrm{H}$ for early in vitro assays, driven by the cheaper preparation of such species, and ${ }^{14} \mathrm{C}$ for later in vivo studies due to of the potential risk of losing a tritium label upon oxidative biotransformation and the possibility of inducing metabolic isotope effects (see section 2.1.3). ${ }^{[281]}$ However, this risk can be also mitigated by careful selection of labeling positions and mediated by the application of modern, highly selective hydrogen isotope exchange chemistry.

Because of their relatively low costs and more straightforward access, tritium labeled compounds can provide a valuable tool to allow early assessment of reactive metabolite formation which is considered to be linked to idiosyncratic adverse drug reactions, such as drug-induced liver injury (DILI). ${ }^{[11]}$ Nucleophilic trapping agents such as Glutathione (GSH) are applied in early stages of drug discovery for reactive metabolite detection (see also section 2.2.2) ${ }^{[312]}$ However, at candidate selection stage, typically covalent binding assays are conducted by incubating radiolabeled drug candidates with human microsomes or hepatocytes.[ 313 ] Generally, after incubation, residual radioactivity bound to the protein is measured following protein precipitation, isolation, and extensive washing steps. ${ }^{[314]}$
In vitro metabolism cross-species comparison studies with radiolabeled drug candidates in hepatocellular and subcellular fractions (e.g. rodent, non-rodent, and human) and/or recombinant human enzymes provide valuable information on metabolic pathways of new chemical entities. ${ }^{[315]}$ Additionally, the radioactivity allows for a quantitative interspecies comparison to ensure that all major metabolites identified in the human in vitro system also have a comparable exposure in the animal species selected for long-term safety assessment. ${ }^{[316]}$ In order to correlate these in vitro generated metabolite profiles, or reactive metabolite findings, with the situation in vivo, radiolabeled analogues of drug development candidates are frequently administered to preclinical species. Besides an identification and quantification of circulating and excreted metabolites, the main objectives of radiolabeled ADME studies may be to determine clearance mechanisms and mass balance (through radioactivity recovery). ${ }^{[317]}$

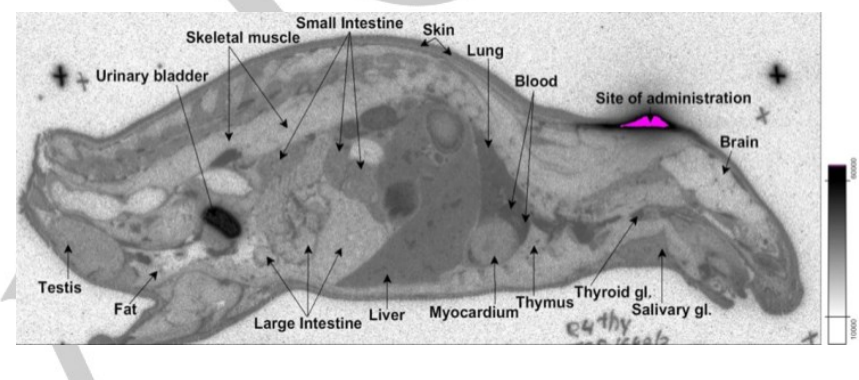

Scheme 31. Quantitative Whole Body Audioradiography (QWBA) following subcutaneous administration of a tritium labeled drug development candidate.

QWBA (Quantitative Whole Body Audioradiography) is a convenient in vivo imaging method which provides qualitative and quantitative information on drug distribution and pharmacokinetics by measuring drug-related radioactivity from whole body slices or organ sections (Scheme 31). ${ }^{[18]}$ In an in vivo sense, these data are important to assess whether the drug reaches the target organ or accumulates in tissues associated with potential safety issues. QWBA studies are routinely conducted for small molecule drug candidates to calculate the maximum radioactive dose that can be administered to humans in the radiolabeled human ADME study. ${ }^{[319]}$ More recently, this technique has also been increasingly utilized to determine biodistribution of biotherapeutic drugs, such as antibody-drug conjugates, oligonucleotides, fusion proteins, and peptides. ${ }^{[320]}$

In conjunction with QWBA, micro-audioradiography (MARG) is a histological technique that relies, in particular, on tritium due to the short path length of the emitted $\beta$-particle providing high spatial resolution and, thus, tissue distribution information at the cellular level. [321] MARG is used to address mechanistic questions, for example the investigation of receptor binding even on the cell surface, and/or to study drug distribution at specific sites of individual organs, such as the brain, eye or skin, in order to address specific toxicities. ${ }^{[322]}$ Recently, the MARG technique was also used to study distribution of humic substances in tissues of wheat seedlings using tritiated humic acid derived from leonardite (a variety of lignites). ${ }^{[323]}$ However, it should be also noted that micro-audioradiography imaging requires prolonged exposure time of up to 3-12 months because of the weak energy emitted by tritium. In spite of the very high spatial resolution of this technique this is often considered too long to address pressing mechanistic questions in drug discovery. 


\section{Conclusions \& Outlook}

The unique MS-pattern obtained from natural and labeled isotopologues drastically simplifies analysis and provides a wealth of inspiring information and previously unprecedented levels of insight from a wide and continuously growing range of applications in many disciplines within the life sciences and beyond. The ability to measure naturally abundant isotope ratios has paved the way for a number of scientific breakthroughs in forensic sciences, geochemistry, ecology, and physiology. Additionally, analytical approaches incorporating stable isotopes have delivered now indispensable tools for relative and absolute quantification, for delineation of cellular metabolism, and for investigation of responses to various stimuli. Having stated this, perhaps most importantly, the employment of such methods provides a dynamic view on biosynthethic pathways, protein turnover, and systems-wide metabolic networks. Indeed, further expansion of isotope labeling to the whole-systems level, together with recent advances in bioinformatics, will bring us closer to a true systems biology understanding.

The combination of new ultra-sensitive mass spectrometry with stable isotope labeling techniques has advanced to a point that some radioactive studies can now be readily replaced by stable-isotope techniques. This tendency is expected to continue with such isotope approaches becoming key components of the new clinical study designs currently being persued, increasing the patient safety due to the circumvention of the radioactive dose. Furthermore, with the employment of stable isotopes having the potential to become even more commonplace in metabolomics, proteomics, clinical pharmacology, and other associated areas, it is expected that the need for stable isotopically labeled compounds will further increase.

In spite of a general tendency for replacement of radiotracer studies in favour of, for example, stable or affinity tags in areas such as proteomics, metabolomics, and breath testing, tritium has recently seen increased use, particularly in pharmaceutical drug discovery. It is expected that this tendency will continue because the efforts and costs required for the synthesis of radiolabeled compounds is out-balanced by the strong sensitivity increase and high reliability of the data obtained. Consequently, highly efficient, cost-effective, and selective synthesis methods for hydrogen isotope labeling of target molecules are required. As there is no other general option to attach a mass tag or a radioactive label to an organic molecule, it can be expected that isotopically labeled compounds will remain an important tool in life sciences in the future.

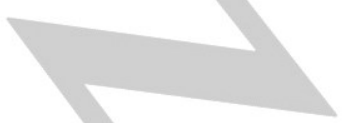

\section{Acknowledgements}

We are grateful to the Leverhulme Trust the provision of an Early Career Fellowshipo (MR) and to GlaxoSmithKline (GSK) for further financial support.
Keywords: • hydrogen isotope exchange $\cdot \bullet$ drug discovery $•$ hydrogen isotope applications,

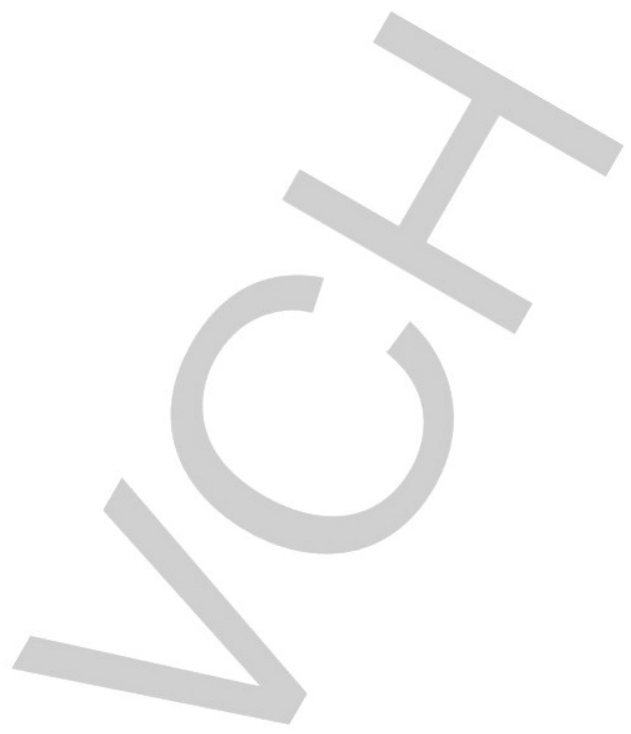

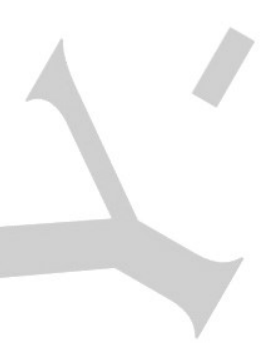


REVIEW

Hydrogen isotopes are unique tools to identify and understand biological or chemical processes. In this review advances in the field of hydrogen isotope applications in a broad spectrum of disciplinary areas in life sciences are described.

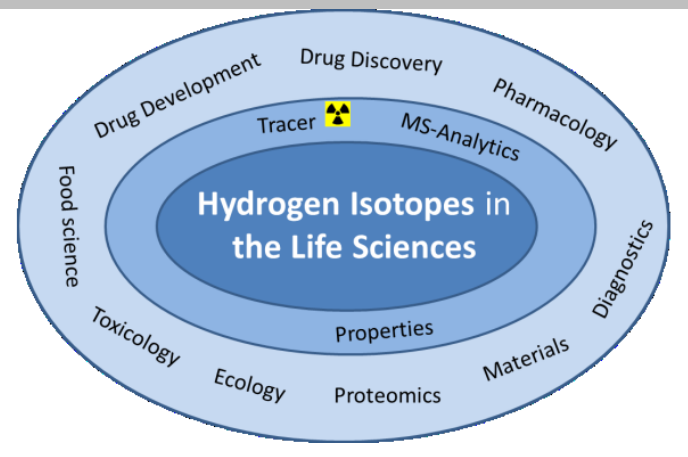

Jens Atzrodt, Volker Derdau, William J. Kerr and Marc Reid

Page No. - Page No.

Applications of Hydrogen Isotopes in the Life Sciences 


\section{References}

J. Yang, Deuterium: Discovery and Applications in Organic Chemistry Elsevier, 2016

M. Larance, A.I. Lamond, Nat. Rev. Mol. Cell Biol. 2015, 16, 269-280. a) S.L. Harbeson, R.D. Tung, Med. Chem. News 2014, 2, 8-22; T.G.

Gant, J. Med. Chem. 2014, 57(9), 3595-3611; c) N.A. Meanwell, J. Med Chem. 2011, 54, 2529-2591.

W.J.S. Lockley, A. McEwen, R. Cooke, J. Label. Compd. Radiopharm. 2012, 55, 235-257

a) C.S. Elmore, R.A. Bragg, Bioorg. Med. Chem. Lett. 2015, 25, 167171; b) C.N. Filer, J Label Compd Radiopharm. 2017, 60, 96-109; c) P.Uhl, G. Fricker, U. Haberkorn, W. Mier, Drug Disc. Today 2015, 20(2), 198-208.

R. Voges, R. Heys, T. Moenius, Preparation of Compounds labeled with Tritium and Carbon-14, Wiley 2009, Chichester, UK.

J. Atzrodt, J. Allen "Synthesis of radiolabelled compounds for clinical studies" in Drug Discovery and Evaluation; Methods in clinical Pharmacology ed. H.-G. Vogel, J. Maas, A. Gebauer, Springer Verlag, Heidelberg 2010, 105-118.

J. Atzrodt, V. Derdau, T. Fey, J. Zimmermann, Angew. Chem. Int. Ed. $2007,46,7744-7765$

a) W.J.S. Lockley, J.R. Heys, J. Label. Compd. Radiopharm. 2010, 53 635-644; b) T. Junk, W. J. Catallo, Chem. Soc. Rev. 1997, 26, 401-406; c) N. Elander, J. R. Jones, S.-Y. Lu, S. Stone-Elander, Chem. Soc. Rev. 2000, 29, 239-249; c) M. Siskin, A. Katritzky, Chem. Rev. 2001, 101 $825-835$ d) J. R. Heys, J. Label. Compd. Radiopharm. 2010, 53, 716 721; e) Y. Sawama, Y. Monguchi, H. Sajiki, Synlett 2012, 23, 959-972.

10 a) M. Hatano, T. Nishimura, H. Yorimitsu, Org. Lett. 2016, 18(15) 3674-3677; b) W. Bai, K. H. Lee, S. K. S. Tse, K. W. Chan, Z. Lin, G. Jia, Organometallics 2015, 34, 3686-3698; c) S. Ma, G. Villa, P. S Thuy-Boun, A. Homs, J.-Q. Yu, Angew. Chem. Int. Ed. 2014, 53, 734 737; d); N. Modutlwa, T. Maegawa, Y. Monguchi, H. Sajiki, J. Label. Compd. Radiopharm. 2010, 53, 686-692.

11 a) D. Hesk, C.F. Lavey, P. McNamara, J. Label. Compd. Radiopharm. 2010, 53, 722-730; b) M.R. Chappelle, C.R. Hawes, J. Label. Compd. Radiopharm. 2010, 53, 745-751; c) C.N. Filer, J. Label. Compd. Radiopharm. 2010, 53, 739-744; d) S.R. Pollack, D.J. Schenk, J. Labe Compd. Radiopharm. 2015, 58 433-441; e) V.P. Shevchenko, I.Y. Nagaev, N.F. Myasoedov, J. Label. Compd. Radiopharm. 2010, 53 693-703.

J. Atzrodt, V. Derdau J. Label. Compd. Radiopharm. 2010, 53, 674-685. J. Atzrodt, V. Derdau, W. J. Kerr, M. Reid, submitted.

A. Kohen, H.-H. Limbach, Eds. Isotope Effects in Chemistry and Biology; CRC Press, Boca Raton, FL, 2006.

R.A.M. O'Ferrall, J. Phys. Org. Chem. 2010, 23, 572-579.

16 a) K.B. Wiberg, Chem. Rev. 1955, 55, 713-743; b) F. H. Westheimer Chem. Rev. 1961, 61, 265-273; c) J. P. Klinman, J. Phys. Org. Chem. 2010, 23, 606-612

17 K.C. Westaway, J. Label. Compd. Radiopharm. 2007, 50, 989-1005

18 a) G.-B. Shen, K. Xia, X.-T. Li, J.-L. Li, Y.-H. Fu, L. Yuan, X.-Q. Zhu, J. Phys. Chem. A. 2016; b) D. Roston, Z. Islam, A. Kohen, Molecules, 2013, 18, 5543-5567; c) J.P. Klinman, A. Kohen, Annu. Rev. Biochem. 2013, 82, 471-496.

19 D. Wade, Chem. Biol. Interact. 1999, 117, 191-217.

20 a) Y. Fang, S. MacMillar, J. Eriksson, M. Kolodziejska-Huben, A Dybala-Defratyka, P. Paneth, O. Matsson, K.C. Westaway, J. Org. Chem. 2006, 71, 4742-4747; b) K.C. Westaway, Y. Fang, S. MacMillar O. Matsson, R.A. Poirier, S.M. Islam J. Phys. Chem. A, 2007, 111(33) 8110-8120.

21 a) K.A. Manning, B. Sathyamoorthy, A. Eletsky, T. Szyperski, A.S. Murkin, J. Am. Chem. Soc. 2012, 134, 20589-20592; b) D.A. Singleton, A.A. Thomas, J. Am. Chem. Soc. 1995, 117, 9357-9358; c) D.A Singleton, M.J. Szymanski, J. Am. Chem. Soc. 1999, 121, 9455-9456.

S. Lu, W.-W. Li, D. Rotem, E. Mikhailova, H. Bayley, Nat. Chem. 2010 2, 921-928.

23 a) A. Pabis, R. Kaminski, G. Ciepielowski, S. Jankowski, P. Paneth, J. Org. Chem. 2011, 76, 8033-8035; b) J. Chan, A.R. Lewis, M. Gilbert M.-F. Karwaski, A.J. Bennet, Nat. Chem. Biol. 2010, 6, 405-407; c) KA. Manning, B. Sathyamoorthy, A. Elesky, T. Szyperski, A.S. Murkin, J. Am. Chem. Soc. 2012, 134, 20589-20592.

24 a) P. Liuni, E. Olkhov-Mitsel, A. Orellana, D.J. Wilson, Anal. Chem 2013, 85, 3758-3764.

25 M.P. Meyer, in Advances in Physical Organic Chemistry, Volume 46 edited by I. Williams, N. Williams, Elsevier, London, UK 2012, pp.57114

26 G. Parkin, J. Label. Compd. Radiopharm. 2007, 50, 1088-1114 E.M. Simmons, J.F. Hartwig, Angew. Chem. 2012, 124, 3120-3128; Angew. Chem. Int. Ed. 2012, 51, 3066-3072.

T. Giagou, M.P. Meyer, Chem. Eur. J. 2010, 16, 10616-10628.

29 a) M. Gomez-Gallego, M.A. Sierra, Chem. Rev. 2011, 111, 4857-4963; b) G.C. Lloyd-Jones, M.P. Munoz, J. Label. Compd. Radiopharm. 2007 50, 1072-1087.

30 a) S. Hammes-Schiffer, Acc. Chem. Res. 2006, 39, 93-100; b) M.H.V. Huynh, T.J. Meyer, Chem. Rev. 2007, 107, 5004-5064; c) A.
Fernandez-Ramos, J.A Miller, S.J. Klippenstein, D.G. Truhlar, Chem. Rev. 2006, 106, 4518-4584; d) Z.D. Nagel, J.P. Klinman, Chem. Rev. 2006, 106, 3095-3118; e) D. Antoniou, J. Basner, S. Nunez, S.D. Schwartz, Chem. Rev. 2006, 106, 3170-3187; f) J. Pu, J. Gao, Donald G. Truhlar, Chem. Rev. 2006, 106, 3140-3169.

31 a) B.R. Ussing, C. Hang, D.A. Singleton, J. Am. Chem. Soc. 2006, 128 7594-7607; b) J.B. Thomas, J. R. Waas, M. Harmata, D.A. Singleton, J. Am. Chem. Soc. 2008, 130, 14544-14555; c) Y. Oyola, D.A. Singleton, J. Am. Chem. Soc. 2009, 131, 3130-3131.

32 a) M. Miyashita, M. Sasaki, I. Hattori, M. Saki, K. Tanino, Science, 2004, 495-496; b) G.B. Dudley, S.J. Danishefsky, G. Sukenick, Tetrehdron Lett. 2002, 43, 5605-5606.

33 K.W. Quasdorf, A.D. Huters, M.W. Lodewyk, D.J. Tantillo, N.K. Garg, J. Am. Chem. Soc. 2012, 134, 1396-1399.

34 a) E. Vedejs, J. Little, J. Am. Chem. Soc. 2002, 124, 747-749; b) J. Clayden, J.H. Pink, N. Westlund, F.X. Wilson, Tetrehdron Lett. 1998, 39 8377-8380; c) F. Hammerschmidt, S. Schmidt, Eur. J. Org. Chem. 2000 2239-2245; d) D.J. Pippel, G.A. Weisenburger, N.C. Faibish, P. Beak, J. Am. Chem. Soc. 2001, 123, 4919. see also b) J. Atzrodt, V. Derdau, J. Label. Compd. Radiopharm. 2005, 48, 171-177.

35 J. Baldwin, J. Label. Compd. Radiopharm. 2007, 50, 947-960

36 J. Rinkel, J.S. Dickschat, Beilstein J. Org. Chem. 2015, 11, 2493-2508. J.L. Holmes, K.J. Jobst, J.K. Terlouw, J. Label. Compd. Radiopharm. 2007, 50, 1115-1123

38 a) K. Francis, A. Kohen, Persp. Sci. 2014, 1, 110-120; b) W.W. Cleland, Arch. Biochem. Biophys. 2005, 433, 2-12; c) P.F. Cook in Enzyme Mechanism from Isotope Effects, 1991, CRC Press, Boca Raton, FL.

39 a) M.D. Toney, J.N. Castro, T.A. Addington, J. Am. Chem. Soc. 2013 135, 2509-2511; b) J.P. Klinman, Proc. Chem. 2011, 3, 291-305; c) J.P. Klinman, Biochemistry, 2013, 52(12), 2068-2077.

40 a) P.F. Fitzpatrick, Arch. Biochem. Biophys. 2010, 493, 13-25; b) J.P Klinman, Acc. Chem. Res. 2007, 40, 325-333; c) G. Chowdhury, M.W. Calcutt, F.P. Guengerich, J. Biol. Chem. 2010, 285(11), 8031-8044. R.H. Hoff, A.C. Henge, J. Label. Compd. Radiopharm. 2007, 50, 10261038.

42 H. Gong, S. Zhang, Molecules 2013, 18, 9278-9292.

43 W.W. Cleland, J. Label. Compd. Radiopharm. 2007, 50, 1006-1015. E.J. Loveridge, E.M. Behiry, J. Guo, R.K. Allemann, Nat. Chem. 2012 4, 292-297.

45 A. Sen, A. Yahashiri, A. Kohen, Biochemistry 2011, $50,6462-6468$ F.P. Guengerich, Chem. Res. Toxicol. 2008, 21(1), 70-83.

A. Dudda, G.-U. Kürzel, In Drug Discovery and Evaluation Safety and Pharmacokinetic Assays; H. Vogel, F. Hock; J. Maas, D. Mayer, Eds Springer: Berlin, Heidelberg, New York, 2006, pp 151-193.

48 a) S.D. Nelson, W.F. Trager, Drug Metab. Dispos. 2003, 31(12), 1481 1498; b) F.P. Guengerich, Chem. Res. Toxicol. 2001, 14(6), 611-650 c) G. Chowdhury, M.W. Calcutt, L.D. Nagy, F.P. Geungerich Biochemistry 2012, 51, 9995-10007.

49 a) F.P. Guengerich, J. Label. Compd. Radiopharm. 2013, 56, 428-431; b) A.H. Meyer, A. Dybala-Defratyka, P.J. Alaimo, I. Geronimo, A.D. Sanchez, C.J. Cramer, M. Elsner, Dalton Trans. 2014, 43, 1217512186.

R. Sharma, T.J. Strelevitz, H. Gao, A.J. Clark, K. Schildknegt, R.S. Obach, S.L. Ripp, D.K. Spracklin, L.M. Tremaine, A.D.N. Vaz, Drug Metab. Dispos. 2012, 40,625-634.

a) N.B. Pestov, I.A. Okkelman, V.V. Shmanai, A.L. Hurski, A.J. Giaccia M.S. Shchepinov, Bioorg. Med. Chem. Lett. 2011, 21, 255; b) R.V. Dunn, K.R. Marshall, A.W. Munro, N.S. Scrutton, FEBS J. 2008, 275, 3850 .

52 a) S. Nag, P. Fazio, L. Lehmann, G. Kettschau, T. Heinrich, A. Thiele M. Svedberg, N. Amini, S. Leesch, A.M. Catafau, J. Hannestad, A. Varrone, C. Halldin, J. Nucl. Med. 2016, 57(2), 315-320; b) S. Nag, L. Lehmann, G. Kettschau, M. Toth, T. Heinrich, A. Thiele, A. Varrone, C. Halldin, Bioorg. Med. Chem. 2013, 21, 6634-6641; c) J.S. Fowler, J. Logan, G.-J. Wang, N.D. Volkow, F. Telang, W. Zhu, D. Franceschi, C Shea, V. Garza, Y. Xu, Y.-S. Ding, D. Alexoff, D. Warner, N. Netusil, P Carter, M. Jayne, P. King, P. Vaska, J. Nucl. Med. 2005, 46 (9), 1414 1420; d) R.M. Baldwin, J. Nucl. Med. 2005, 46 (9), 1411-1413.

53 a) L. Shao, M.C. Hewitt, Drug News Persp. 2010, 23(6), 398-404; b) D.J. Kushner, A. Baker, T.G. Dunstall, Can. J. Physiol. Pharmacol. 1999, 77(2), 79-88.

54 a) C. Elison, H. Rapoport, R. Laurson, H.W. Elliott, Science, 1961, 134, 1078-1079; b) C. Elison, H.W. Elliott, M. Look, H. Rapoport, J. Med. Chem. 1963, 6, 237-246; c) A.B. Foster, Adv. Drug Res. 1985, 14, 2; d) G.K. Darland, R. Hajdu, H. Kropp, F.M. Kahan, R.W. Walker, W.J. Vandenheuvel, Drug Metab. Dispos. 1986, 14(6), 668-678; e) M.I. Blake, H.L. Grespi, J.J. Katz, J. Pharm. Sci. 1975, 64(3), 367-391; f) K.M. Dewar, L.E. Dyck, D.A, Durden, Biochem. Pharmacol. 1988 37(13), 2703-2704.

55 a) B. Halford, Chem. Eng. News 2016, 94(27), 32-36; b) The Economist 2015 Septmber $5^{\text {th. }}$ c) R.H. Howland, J. Psychosoc. Nurs Men 2015 53(9), 13-16; d) A. Katsnelson, Nat. Med. 2013, 19(6), 656; e) R Schillerstrom, Drug Disc. Dev. 2009, 12(5), 6-8; f) K. Sanderson, Nature 2009, 458, 269; g-) A.T. Yarnell, Chem. Eng. News 2009, 87(25), 36-39. 
$56 \quad$ More than 300 patent applications have been filled by companies like Concert, Auspex, Protia, Deuteria and Deuterx. Recent examples: a) S.L. Harbeson, US20140024652, 2014; b) R.D. Tung, US20140018390 2014; c) R.D. Tung, C.E. Masse US20140018379, 2014; d) A.W. Czarnik, US20140018436, 2014; e) B. Pandya, C.E. Masse, I.R. Silverman US20140005211, 2014; f) C. Ling, G. Chen, G. Chen, Z Zhang, B. Gao, K. Han, J. Yin, A. Chu, Y. Zhao, X. Mao, Int. J. Cancer 2012, 131, 2411-2419.

57 K.C. Buteau, Jigh Tech. Law 2009, $22,22-74$.

58 G.S. Timmins, Expert Opin. Ther. Patents, 2014, 24(10), 1067-1075. M.B. Fisher, K.R. Henne, J. Boer, Curr. Opin. Drug Disov. Dev. 2006 9(1), 101-109

60 a) J. Schofield, V. Derdau, J. Atzrodt, P. Zane, Z. Guo, R. van Horn, V. Czepczor, A. Stoltz, M. Pardon, Bioorg. Med. Chem. 2015, 23, 3831 3842; b) P.W. Manley, F. Blasco, J. Mestan, R. Aichholz, Bioorg. Med Chem. 2013, 21, 3231-3239; c) R.A. Stringer, G.W.F. Picard, B. Sohal O. Kretz, J. McKenna, J.A. Krauser, Drug Metab. Dispos. 2014, 42, 954-962; d) E.J. Velthuisen, T.M. Baughman, B.A. Johns, D.P. Temelkoff, J.G. Weatherhead, Eur. J. Med. Chem. 2013, 63, 202-212 R.D. Tung, Future Med. Chem. 2016, 8(5), 491-494. A. Mullard, Rev. Drug Discov. 2017, 16, 305

Teva Pharmaceutical Industries Ltd. Press Release 2016, October 20, http://www.tevapharm.com/news

64 a) Concert Pharmaceuticals, Inc. Press Release 2014, July 08 http://ir.concertpharma.com/releasedetail.cfm?releaseid=858155; L.A. Sabounjian, P. Graham, L.Wu, V. Braman, C. Cheng, J. Liu, J. Shipley, J. Neutel, M Dao, Clin. Pharmacol. Drug Dev. 2016, 5, 1-12; b) V. Braman, P. Graham, C. Cheng, D. Turnquist, M. Harnett, L.A Sabounjian, J. Shipley, Clin. Pharmacol. Drug Dev. 2013, 2(1), 53-66 c) X. Tanga, G. Bridsonb, J. Kea, L. Wub, H. Erol, P. Grahamb, C.H. Lina, V. Bramanb, H. Zhaoa, J.F. Liub, Z. Lina, C. Cheng, J. Chromatogr. B, 2014, 963, 1-9.

65 Avanir Pharmacuticals. Inc. Press Release 2015, November 16 http://www.avanir.com/press/

66 AVP-786 is an investigational drug product consisting of a combination of deuterated (d6)-dextromethorphan and an ultra-low dose of quinidine required as an inhibitor of the enzyme CYP 2D6.

67 please see also: http://ir.concertpharma.com/releases.cfm http://investor.auspexpharma.com/releases.cfm

68 a) F. Maltais, Y.C. Jung, M. Chen, J. Tanoury, R.B. Perni, N. Mani, L. Laitinen, H. Huang, S. Liao, H. Gao, H. Tsao, E. Block, C. Ma, R.S Shawgo, C. Town, C.L. Brummel, D. Howe, S. Pazhanisamy, S Raybuck, M. Namchuk, Y.L. Bennani, J. Med. Chem. 2009, 52, 7993 8001 ; b) G. Xu, B. Lv, J.Y. Roberge, B. Xu, J. Du, J. Dong, Y. Chen, K Peng, L. Zhang, X. Tang, Y. Feng, M. Xu, W. Fu, W. Zhang, L. Zhu, Z Deng, Z. Sheng, A. Welihinda, X. Sun, J. Med. Chem. 2014, 57, 1236 1251; c) F. Schneider, M. Hillgenberg, R. Koytchev, R.G. Alken, Drug Res. 2006, 56, 295-300; d) F. Schneider, E. Mattern-Dogru, M. Hillgenberg, and R.G. Alken, Drug Res. 2007, 57, 293-298.

a) A. Mullard, Nat. Rev. Drug Disc. 2016, 15, 219- 221; b) http://deuterx.com/

A.E. Mutilib, Chem. Res. Toxicol. 2008, 21, 1672-1689.

R.D. White, A.J. Gandolfi, F.T. Bowden, I. G. Sipes, Toxicol. Appl. Pharmacol. 1983, 69, 170-178.

R.V. Branchflower, D.S. Nunn, R.J. Highet, J.H. Smith, J.B. Hook, L.R. Pohl, Toxicol. Appl. Pharmacol. 1984, 72, 159-168.

A.W. Czarnik, J.A. McKinney, US2011/0046236 A1 2011.

A.E. Mutlib, P. Jiang, J. Atherton, L. Obert, S. Kostrubsky, S. Madore, S Nelson, Chem. Res, Toxicol. 2006, 19(10), 1270-1283.

D. Wade, Chem. Bio. Interact. 1999, 117, 191-217.

a) C.N. Filer, J. Label. Compd. Radiopharm. 1999, 42, 169-197; b) J. Wieling, Chromatogr. Suppl. 2002, 55, S107-S113; c) S.S. Iyer, Z.P. Zhang, G.E. Kellogg, H.T. Karnes, J. Chromatogr Sci. 2004, 42, 383 387 ; K. Kato, S. Jingu, N. Ogawa, S. Higuchi, J. Pharm. Biomed. Anal. 2000, 24, 237-249.

77 a) M.I. Churchwell, N.C. Twaddle, L.R. Meeker, D.R. Doerge, J. Chromatogr. B 2005, 825, 134; b) L. Novakova, L. Matysova, P. Solich Talanta 2006, 68, 908; c) M.E. Swartz, J. Liq. Chrom. Relat. Technol. 2005, 28, 1253.

78 a) S. Wang, M. Cyronak, E. Yang, J. Pharm. Biomed. Anal. 2007, 43 701-707; b) T. Berg, D.H. Strand, J. Chromatogr. A 2011, 1218, 93669374.

79 R. Zhang, C.S. Sioma, R.A. Thompson, L. Xiong, F.E. Regnier, Anal Chem. 2002, 74, 3662-3669.

Martin Sandvoss, Sanofi, unpublished results

81 a) N. Lindegardh, A. Annerberg, N.J. White, N.P. Day, J. Chromatogr. B 2008, 862, 227-236; b) M. Turowski, N. Yamakawa, J. Meller, K Kimata, T. Ikegami, K. Hosoya, N. Tanaka, E.R. Thornton, J. Am. Chem. Soc. 2003, 125, 13836-13849; c) A. Valleix, S. Carrat, C. Caussignac, E. Leonce, A Tchapla, J. Chromatogr. B 2006, 1116, 109126.

82 H. Maehr, N. Rochel, H.J. Lee, N. Suh, M. Uskokovic, J. Med. Chem. 2013, 56, 3878-3888

83 a) R.P. White, J.E.G. Lipson, J.S. Higgins, Macromol. 2010, 43, 4287 4293; b) H. Yang, M. Shibayama, R.S. Stein, N. Shimizu, T. Hashimoto, Macromol. 1986, 19, 1667-1674.
J.W Jiang, J. Lan, J.-S. Wang, B. Li, J Appl. Phys, 2010, 107, 054314-054315.

85 T.D. Nguyen, G. Hukic-Markosian, F. Wang, L. Wojcik, X.-G. Li, E. Ehrenfreund, Z.V. Vardeny, Nat. Mater. 2010, 9, 345-352.

86 M. Shao, J. Keum, J. Chen, Y. He, W. Chen, J.F. Browning, J. Jakowski, B.G. Sumpter, I.N. Ivanov, Y.-Z. Ma, C. M. Rouleau, S.C. Smith, D.B. Geohegan, K. Hong, K. Xiao, Nat. Commun. 2014, 5, 3180 W.R. Browne, J.G. Vos, Coord. Chem. Rev. 2001, 219-221, 761-787.

88 C.C. Tong, K.C. Hwang, J. Phys. Chem. C 2007, 111, 3490-3494.

89 a) P. Wang, F.-F. Wang, Y. Chen, Q. Niu, L. Lu, H.-M. Wang, X.-C Gao, B. Wei, H.-W. Wu, X. Cai, J. Mater. Chem. C 2013, 1, 4821-4825 b) T. Abe, A. Myazawa, H. Konno, Y. Kawanishi, Chem. Phys. Lett 2010, 491, 199-202.

90 a) C. Bischof, J. Wahser, J. Scholten, S. Trosien, M. Seitz, J. Am Chem. Soc. 2010, 132, 14334-14335; b) J. Scholten, G.A. Rosser, J. Wahser, N. Alzakhem, C. Bischof, F. Stog, A. Beeby, M. Seitz, J. Am Chem. Soc. 2012, 134, 13915-13917.

91 a) A.M. Krause-Heuer, N.R. Yepuri, T. A Darwish P.J. Holden, Molecules 2014, 19, 18604-18617; b) H. Tsuji, C. Mitsui, E. Nakamura, Chem. Comm. 2014, 50, 14870-14872; c) T.A. Darwish, A.R.G. Smith I.R. Gentle, P-L. Burn, E. Luks, G. Moraes, M. Gillon, P.J. Holden, M. James, Tetrahedron Lett. 2012, 53, 931-935.

92 F. Sabeth, T. limori, N. Ohta, J. Am. Chem. Soc. 2012, 134, 6984-6986. a) J.S. Higgins, Annu. Rev. Chem. Biomol. Eng. 2016 7, 1-28; b) M. Shibayama, Polym. J. 2011, 43, 18-34.

94 a) M. Haertlein, M. Moulin, J.M. Devos, V. Laux, O. Dunne, V.T, Forsyth, Methods Ezymol. 2016, 566, 113-149; b) N.R. Zaccai, C.W. Sandlin, J.T. Hoopes, J.E. Curtis, P.J. Fleming, K.G. Fleming, S Krueger, Methods Ezymol. 2016, 566, 159-210; c) F. Henrich, Methods Ezymol. 2016, 566, 211-230; d) J.F. Ankner, W.T. Heller, K.W. Herwig, F. Meilleur, D.A.A. Myles, Curr. Protoc. Protein Sci. 2013, 72, 17.16.117.16.34

a) P. Lesot, O. Lafon, J. Courtieu, P. Berdague, Chem. Eur. J. 2004, 10, 3741-3746 ; b) K. Kimato, M. Kobayashi, K. Hosya, T. Araki, N. Tanaka J. Am. Chem. Soc. 1996, 118, 759-762.

a) K.-S. Cheon, M.M. Green, J. Label. Compd. Radiopharm. 2007, 50 961-966; b) M.M. Green, C. Andreola, B. Munoz, M.P. Reidy, J. Am. Chem. Soc. 1988, 110, 4063-4065

S. Cantekin, D.W.R. Balkenende, M.M.J. Smulders, A.R.A. Palmans, E.W. Meijer, Nat. Chem. 2011, 3, 42-46.

a) M.M. Green, J.-W. Park, T. Sato, A. Teramoto, S. Lifson,, R.L.B. Selinger, J.V. Selinger, Angew. Chem. Int. Ed. 1999, 38, 3138-3154; b) J. van Gestel, Macromol. 2004, 37(10), 3894-3898

99 a) T. Kawasaki, K. Soai, J. Fluorine Chem. 2010, 131, 525-534; b) T. Kawasaki, M. Shimizu, D. Nishiyam, M. Ito, H. Ozawa, K Soai, Chem. Commun. 2009, 4396-4398; c) I. Sato, D. Omiya, T. Saito, K. Soai, J. Am. Chem. Soc. 2000, 122, 11739-11740; d) B. Barabas, L. Caglioti, K Micskei, C. Zucchi, G. Palyi, Orig. Life Evol. Biosph. 2008, 38, 317-327

e) T. Kawasaki, Y. Matsumura, T. Tsutsumi, K. Suzuki, M. Ito, K. Soai, Science 2009, 324, 492-495.

a) K. Merz, A. Kupka, Cryst. Chrowth. Des. 2015, 15(4), 1553-1558; b) S. Crawford, M.T. Kirchner, D. Bläser, R. Boese, W.I.F. David, A Dawson, A. Gehrke, R.M. Ibberson, W.G. Marshall, S. Parsons, O. Yamamuro, Angew. Chem. Int Ed 2009, 48, 755-757; c) A. Kupka, V. Vasylyeva, D.W.M. Hofmann, K.V. Yusenko, K. Merz, Cryst. Chrowth. Des. 2012, 12(12), 5966-5971; c) J. Zhou, Y.-S. Kye, G.S. Harbison, J. Am. Chem. Soc. 2004, 126, 8392-8393; d) B.C.K. Ip, I.G. Shenderovich, P.M. Tolstoy, J. Frydel, G.S. Denisov, G. Buntkowsky, H.-H. Limbach, J. Phys. Chem. A 2012, 116, 11370-11387.

101 a) C.E. Hughes, K.D.M. Harris, New J. Chem. 2009, 33, 713-716; b) H. Abe, Y. Imai, T. Takekiyo, Y. Yoshimura, J. Phys. Chem. B 2010, 11 2834-2839.

102 a) J.S. Mugridge, R.G. Bergman, K.N. Raymond, J. Am Chem. Soc 2010, 132, 1182-1183; b) T. Haino, K. Fukuta, H. Iwamoto, S. Iwata Chem. Eur. J. 2009, 15, 13286-13290; c) D. Rechavi, A. Scarso, J. Rebek Jr., J. Am. Chem. Soc. 2004, 126, 7738-7739; d) Y.L. Zhao, K.N. Houk, D. Rechavi, A. Scarso, J. Rebek Jr. J. Am. Chem. Soc. 2004 126, 11428-11429; e) Y. Liu, R. Warmuth, Org. Lett. 2007, 9(15), 28832886

103 a) C. Zhao, R.M. Parrish, M.D. Smith, P.J. Pellechia, C.D. Sherrill, K.D. Shimizu, J. Am. Chem. Soc. 2012, 134, 14306-14309. b) Y. Liu, R. Warmuth, Org. Lett. 2007, 9, 2883.

104 W. Meier-Augenstein, H.F Kemp, Stable Isotope Analysis: General Principles and Limitations. Wiley Encyclopedia of Forensic Science, John Wiley \& Sons, Ltd., 2012.

105 M. Thullner, A. Fischer, H.-H. Richnow, L.Y. Wick, Appl Microbiol. Biotechnol. 2013, 97, 441-452

106 W. Meier-Augenstein, K.A. Hobson, L.I. Wassenaar, Bioanalysis 2013 5(7), 751-767

107 a) N. Gentile, R.T.W Siegwolf, P. Esseiva, S. Doyle, K. Zollinger, O. Delemont Forensic Sci. Int 2015, 251, 139-158; b) J.F Carter, V J. Barwick (Eds), Good Practice guide for stable isotope ratio mass spectrometry, FIRMS, 2012; c) J.-P. Godin, J.S.O. McCullagh, Rapid Commun. Mass Spectrom. 2011, 25, 3019-3028 d) S. Benson, C. Lennard, P. Maynard, C. Roux, Forensic Sci. Int. 2006, 157, 1-22; 
108 a) L. Zhao, H. Xiao, J. Zhou, L. Wang, G Cheng, M. Zhou, L. Yin, M.F. McCabe, Rapid Commun. Mass Spectrom. 2011, 25(20), 3071-3082; b) A.G. West, G.R. Goldsmith, P.D. Brooks, T.E. Dawson, Rapid Commun Mass Spectrom. 2010, 24, 1948-1954; c) P. Martin-Gómez, A. Barbeta, J. Voltas, J. Penuelas K. Dennis, S. Palacio, T.E. Dawson, J.P. Ferrio, New Phytol. 2015, 207(3), 914-927.

109 a) L. Yang, Mass Spectrom. Rev. 2009, 28, 990- 1011; b) L. Balcaen F. Bolea-Fernandez, M. Resano, F. Vanhaecke, Anal. Chim. Acta. 2015, 894, 7-19; c) I. Rodushkin, E. Engström, D.C. Baxter, Anal. Bioanal. Chem. 2013, 405, 2785-2797.

110 a) Y. Oulhote, B. Le Bot, S. Deguen, P. Glorennec, Trends Analyt. Chem. 2011, 30(2), 302-312; b) W. Meier-Augenstein Stable Isotop Forensics: an Introduction to the Forensic Application of Stable Isotope Analysis. Wiley-Blackwell, Hoboken, NJ USA, 2010; c) C.M. del Rio, N. Wolf, S.A. Carleton, L.Z. Gannes, Biol. Rev. 2009, 84, 91-111; d) N Wolf, S.A. Carleton, C. M. del Rio, Funct. Ecol. 2009, 23, 17-26; e) W.J. Boecklen, C.T. Yarnes, B.A. Cook, A.C. James, Annu. Rev. Ecol. Evol. 2012, 42, 411-440;

111 a) S.A. Drivelos, C.A. Georgiou, Trends Anal. Chem. 2012, 40, 38-51; b) Y. Zhao, B. Zang, G. Chen, A. Chen, S. Yang, Z. Ye, Food Chem 2014, 145, 300-305.

112 a) P.B. Hatzinger, J.K. Böhlke, N.C. Sturchio, Curr. Opin. Biotechnol. 2013, 24, 542-549; b) G.J. Bowen, D.A. Winter, H.J. Spero, R.A Zierenberg, M.D. Reeder, T.E. Cerling, J.R. Ehleringer, Rapid Commun Mass. Spectrom. 2005, 19, 3442-3450.

113 a) P. Höhener, X. Yu, J. Contam. Hydrol. 2012, 129-130, 54-61; b) M. Elsner, L. Zwank, D. Hunkeler, R.P. Schwarzenbach, Environ. Sci. Technol. 2005, 39, 6896-6916; c) T.B. Hofstetter, M. Berg, Trends Anal. Chem. 2011, 30, 618-627.

114 a) J.P. Jasper, B.J. Westenberger, J.A. Spencer, L.F. Buhse, M. Nasr J. Pharm. Biomed. Anal. 2004, 35, 21-30; b) J.P. Jasper, F. Fourel, A Eaton, J. Morrison, A. Phillips, Pharm. Technol. 2004, 28 (8), 60-67; c) R. Santamaria-Fernandez, R. Hearn, J.-C. Wolff, Sci. Justice 2009, 49 102-106.

115 a) H.A.S. Buchanan, N. NicDaeid, W. Meier-Augenstein, H.F. Kemp, W J. Kerr, M Middleditch, Anal Chem 2008, 80(9), 3350-3356; b) FA Idoine, J.F. Carter, R. Sleeman, Rapid Commun. Mass Spectrom. 2005 19(22), 3207-3215

116 a) S.J. Benson, C.J. Lennard, P. Maynard, D.M. Hill, A.S. Andrew, C. Roux, Sci. Justice 2009, 49(2), 73-80; b) D. Widory, J.J. Minet, M. Barbe-Leborgne, Sci. Justice 2009, 49(2), 62-72; c) C.M. Lock, W Meier-Augenstein, Forensic Sci. Int. 2008, 179(2-3), 157-162; d) W Meier-Augenstein, H.F. Kemp, C.M. Lock, Rapid Commun. Mass Spectrom. 2009, 23(13), 2011-2016; e) J.E. Barnette, M.J. Lott, J.D. Howa, D.W. Podlesak, J.R. Ehleringer, Rapid Commun. Mass Spectrom. 2011, 25(10), 1422-1428.

117 a) B. Jin, M. Rolle, Curr. Opin. Biotechnol. 2016, 41, 178-186; b) D. Hunkeler, R. Aravena, K. Berry-Spark , E. Cox, Environ. Sci. Technol. 2005, 39(16), 5975-5981; c) R.U. Meckenstock, B. Morasch, C. Griebler, H.-H. Richnow, J. Contam. Hydrol. 2004, 75, 215-255.

118 a) X. Zhang, A.L. Gillespie, A.L. Sessions, PNAS, 2009, 106(31) 12580-12586; b) D.L. Valentine PNAS, 2009, 106(31), 12565-12566; c) J. Fang, C. Li, L. Zhang, T. Davis, Chiaki Kato, D.H. Bartlett, Chem Geol. 2014, 367, 34-38; d) S.S. Dirghangi, M. Pagani, Org. Geochem. 2013, 64, 105-111.

119 a) J.J. Middelburg, Biogeosciences, 2014, 11, 2357-2371; b) C.A Layman, M.S. Araujo, R. Boucek, C.M. Hammerschlag-Peyer, E. Harrison, Z.R. Jud, P. Matich, A.E. Rosenblatt, J.J. Vaudo, L.A. Yeager, D.M. Post, S. Bearhop, Biol. Rev. 2012, 87, 545-562; c) H.B.Vande Zanden, D.X. Soto, G.J. Bowen, K.A. Hobsen, Front. Ecol. Evol. 2016 4, 20; d) S. Bouillon, D.P.Gillikin, R.M. Connolly, Use of stable isotopes to understand food webs and ecosystem functioning in estuaries, in Treatise on Estuarine and Coastal Science, edited by E.Wolanski, D.S. McLusky, 7, 143-173, Waltham: Academic Press, 2012.

120 a) K.A. Hobson, L.I. Wassenaar Tracking Animal Migration with Stable Isotopes. Academic Press, Waltham, MA, USA, 2008; b) A. Kelly, R. Thompson, J. Newton, Sci. Justice 2009, 48, 67-70.

121 a) E.J. Bartelink, R. Berry, L.A. Chesson, Stable Isotopes and Human Provenancing, in Advances in Forensic Human Identification, X. Mallett, T. Blythe, R.J. Berry, eds. Bosa Roca: CRC Press, 2014, 157-184; b) E.J. Bartelink, G.E. Berg, M.M. Beasley, L.A. Chesson, Anal. Anthrophol. Pract. 2014, 38.1, 124-136; c) C. Lehn, A. Rossmann, M. Graw, Sci. Justice 2015, 55, 72-88; d) L. Font, G. van der Peijl, C. van Leuwen, I. van Wetten, G.R. Davies, Sci. Justice 2015, 55, 34-42; e) G Vautour, A. Poirier, D. Widory, Sci. Justice 2015, 55, 63-71.

122 a) O.J. Maselli, D. Fritzsche, L. Layman, J.R. McConnell, H. Meyer, Isotopes Environ. Health Stud. 2013, 49(3), 387-398; b)

123 a) A. Gessler, J.P. Ferrio, R. Hommel, K. Treydte, R.A. Werner, R.K Monson, Tree Physiol. 2014, 00, 1-23; b) M.M. Savard, Environ. Pollut 2010, 158(6), 2007-2113; c) S.W. Leavitt, Sci. Total Environ. 2010, 408(22), 5244-5253; d) G.J. Martin, M.L. Martin, Phytochem. Rev. 2003 2, 179-190.

124 a) J.P. Greenwood, S. Itoh, N. Sakamoto, P. Warren, L. Taylor, H. Yurimoto, Nat. Geosci. 2011, 4, 79-82; b) J. Zhang, N. Dauphas, A.M. Davis, I. Leya, A. Fedkin, Nat. Geosci. 2012, 5, 251-255; c) J.J.
Barnes, I.A. Franchi, M. Anand, R. Tartèse, N.A. Starkey, M. Koike, Y Sano, S.S. Russell, Chem. Geol. 2013, 337-338, 48-55.

125 a) S. Messenger, F.J. Stadermann, C. Floss, L.R. Nittler, S. Mukhopadhyay, Space Sci. Rev. 2003, 106(1), 155-172; b) N.A. Starkey, I.A. Franchi, M.R. Lee, Geochim. Cosmochim. Acta 2014, 142 115-131.

126 a) L.J. Hallis, G.J. Taylor, K. Nagashima, G.R. Huss, A.W. Needham M.M. Grady, I.A. Franchi, Geochim. Cosmochim. Acta 2012, 97, 105 119; b) J.P. Greenwood, S. Itoh, N. Sakamoto, E.P. Vicenzi, H. Yurimoto, Geophys. Res. Lett. 2008, 35, L05203; c) L.A. Leshin, P. R. Mahaffy, C. R. Webster, M. Cabane, P. Coll, P.G. Conrad, P.D. Archer Jr., S.K. Atreya, A.E. Brunner, A. Buch, J.L. Eigenbrode, G.J. Flesch, H.B. Franz, C. Freissinet, D.P. Glavin, A.C. McAdam, K.E. Miller, D.W Ming, R.V. Morris, R. Navarro-González, P B. Niles, T. Owen, R.O. Pepin, S. Squyres, A. Steele, J.C. Stern, R.E. Summons, D.Y. Sumner B. Sutter, C. Szopa, S. Teinturier, M.G. Trainer, J.J. Wray, J.P. Grotzinger, MSL Science Team, Science 2013, 341(6153), 1238937.

127 D. Bockelée-Morvan, U. Calmonte, S. Charnley, J. Duprat, C. Engrand A. Gicquel, M. Hässig, E. Jehin, H. Kawakita, B. Marty, S. Milam, A Morse, P. Rousselot, S. Sheridan, E. Wirström, Space Sci. Rev. 2015 197(1) 47-83

128 Modified from a) http://web.sahra.arizona.edu/; b) M. Z. Bruckner http://serc.carleton.edu/microbelife/research methods/environ samplin g/stableisotopes.html based on C. Kenddall, T.B. Coplen, Hydrol. Process. 2001, 15, 1363-1393.

129 a) E. Stovkis, H. Rosing, J.H. Beijnen, Rapid Commun. Mass Spectrom. 2005, 19, 401-407; b) A.K. Hewavitharana, J. Chromatogr. A 2011, 1218, 359-361.

130 a) P.J. Taylor, Clin. Biochem. 2005, 38, 328-334; b) G. Tranfo, A.M. Ciadella, E. Paci, D. Pigini, Prev. Today 2007, 3, 57-64; c) E. Rogatsky, D. Stein, J. Am. Soc. Mass. Spectrum. 2005, 16, 1757-1759.

a) T.M. Annesley, Clin. Chem. 2003, 49, 1041-1044; b) T. Sangster, M. Spencer, P. Sinclair, R. Payne, C. Smith, Rapid Commun. Mass. Spectrom. 2004, 18, 1361-1364; c) F. Gosseti, E. Mazzucco, D. Zampieri, M.C. Gennaro, J. Chromatogr. A 2010, 1217, 3929-3937.

132 a) M. Jemal, Y.-Q. Xia, Curr. Drug. Metabolism 2006, 7, 491-502; b) R.H. Liu, D.-L. Lin, W.-T. Chang, C. Liu, W.-I. Tsay, J.-H. Li, T.-L. Kuo, Anal. Chem. 2002, 74, 618A-626A

V. Derdau, J. Atzrodt, J. Zimmermann, C. Kroll, F. Brückner, Chem. Eur. J. 2009, 15, 10397-10404

a) J. Wu, R. Wiegand, P. LoRusso, J. Li, J. Chromatogr. B 2013, 941 100-108; b) R.E. Savage, T. Hall, K. Bresciano, J. Bailey, M. Starace, T.C.K. Chan, J. Chromatogr. B 2008, 872, 148-153; c) F. Bai, B.B. Freeman III, C.H. Fraga, M. Fouladi, C.F. Stewart , J. Chromatogr. B 2006, 831, 169-175; d) C.M. Chavez-Eng, M.L. Constanzer, B.K. Matustewski, J. Chromatogr. B 2002, 767, 117-129; e) J.J.M.A Hendrikx, H. Rosing, A.H. Schinkel, J.H.M. Schellens, J.H. Beijnen, Bioanalysis 2014, 6, 993-1010.

a) W. Jian, R.W. Edom, Y Xu, J Gallagher, N. Weng, J. Chromatogr. B 2010, 878, 3267-3276; b) H. Nomura, J. Ueyama, T. Kondo, I. Saito, K. Murata, T. Iwata, S. Wakusawa, M. Kamijima, J. Chromatogr. B 2013 $941,109-115$; c) S. Arrivault, M. Guenther, S.C. Fry, M.M.F.F. Fünfgeld, D. Veyel, T. Mettler-Altmann, M. Stitt, J.E. Lunn, Anal. Chem. 2015, 87 , 6896-6904; d) P. Li, Y. Gong, H.-K. Lim, W. Jian, R.W. Edom, R. Salter, J. Silva, N. Weng, J. Chromatogr. B 2013, 926, 92-100.

136 a) J. Atzrodt, J. Blankenstein, D. Brasseur, S. Calvo-Vicente, M. Denoux, V. Derdau, M. Lavisse, S. Perard, S. Roy, M. Sandvoss, J. Schofield, J. Zimmermann, Bioorg. Med. Chem. 2012, 20 5658-5667; b) M. Dasgupta, W. Tang, G.W. Caldwell, Z. Yan, Rapid Commun. Mass. Spect. 2010, 24, 2177-2186; c) K. Kozaki, Y. Amada, M. Oshikata, T. Kawase, E. Suzuki, Y. Haramaki, H. Taniguchi, Drug. Metab. Pharmacokinet. 2012, 27, 520-529; c) K. Nakamura, A. Watanabe, N. Okudaira, O. Okazaki, K. Sudo, Drug. Metab. Pharmacokinet. 2007 22(2), 113-118; d) R.L. Walsky, R.S. Obach, Drug Metab. Dispos. 2004 32, $647-660$

137 a) T. Berg, M. Karlsen, A.M.L. Øiestad, J.E. Johansen, H. Liu, D.H Strand, J. Chromatogr. A 2014, 1344, 83-90; b) C. Metcalfe, Ka Tindale, H. Li, A. Rodayan, V. Yargeau, Environ. Poll. 2010, 158, 3179 3185 ; c) M. Di Rago, M. Chu, L.N. Rodda, E. Jenkins, A. Kotsos, D Gerostamoulos, Anal. Bioanal. Chem. 2016, 1-13.

138 a) T. Piper, C. Emery, M. Saugy, Anal. Bioanal. Chem. 2011, 401(2), 433-447; b) M. Thevis, A. Thomas, S. Beuck, A Butch, J. Dvorak, W. Schänzer, Rapid Commun. Mass Spectrom. 2013, 27, 507-512; c) T. Piper, A. Thomas, M. Thevis, M. Saugy, Drug Test. Anal. 2012, 4, 717 727; d) U. Flenker, L.N. Geppert, K. Ickstadt, Drug Test. Anal. 2012, 4 934-941; e) A.T. Cawley, A.V. George. Drug Test. Anal. 2012, 4, 897 911.

139 a) X. Ye, Z. Kuklenyik, L.L. Needham, A.M. Calafat, J. Chromatogr. B 2006, 831, 110-115; b) B.C. Blount, R.J. Kobelski, D.O. McElprang, D. Ashley, J.C. Morrow, D.M. Chambers, F.L. Cardinali, J. Chromatogr. B 2006, 832, 292-301; c) X Ye, L.J. Tao, L.L. Needham, A.M. Calafat Talanta 2008, 76, 865-871; d) H.M. Koch, A.M. Calafat, Phil. Trans. R. Soc. B 2009, 364, 2063-2078.

140 R.A. Rudel, D.E. Camann, J.D. Spengler, L.R. Korn, J.G. Brody Environ. Sci. Technol. 2003, 37 (20), 4543-4553. 
141 a) N.H. Tran, J. Hu S.L. Ong, Talanta 2013, 113, 82-92; b) R. Loos, R. Carvalho, D.C. Antonio, S. Comero, G. Locoro, S. Tavazzi, B. Paracchini, M. Ghiani, T. Lettieri, L. Blaha, B. Jarosova, S. Voorspoels K. Servaes, P. Haglund, J. Fick, R.H. Lindberg, D. Schwesig, B.M Gawlik, Water Res. 2013, 47, 6475-6487; T. Benijts, R. Dams, W. Lambert, A.D. Leenheer, J. Chromatogr. A 2004, 1029, 153-159.

142 a) G. Hopfgartner, A. Lesur, E. Varesio Trends in Anal. Chem. 2013, 48 52-61; b); b) M. Ewles, L. Goodwin Bioanalysis 2011, 3 , 1379-1397; c I. van den Broek, W.M.A. Niessen, W.D. van Dongen, J. Chromatogr. B 2013, 929, 161-179.

143 a) K.J. Bronsema, R. Bishoff, N.C. van de Merbel, Anal. Chem. 2013 85, 9528-9535; b) H. Hill Bioanalysis 2009, 1, 1359-1364.

144 A. Scherl, Methods, 2015, 81, 2-14.

145 K.J. Bronsema, R. Bishoff, N.C. van de Merbel, J. Chromatogr. B 2012 893-894, 1-14

a) M. Feria, M.S. Halquist, M. Yuan, W. Mylott Jr., R.G. Jenkins, H.T. Karnes, J. Chromatography B 2015, 1001, 156-168; b) O. Heudi, S. Barteau, D. Zimmer, J. Schmidt, K. Bill, N. Lehmann, C. Bauer, O. Kretz, Anal. Chem. 2008, 80, 4200-4207; c) F. Pailleux, F. Beaudry, Biomed. Chromatogr. 2012, 26, 881-891; d) M. Feria, M.S. Halquist, M. Yuan, W. Mylott Jr., R.G. Jenkins, H.T. Karnes, J. Biomed. Chromatogr. 2015, 29, 1780-1782.

147 K. Voronin, A.J. Allentoff, S.J. Bonacorsi Jr., C. Mapelli, S.X. Gong, V. Lee, D. Riexinger, N. Sanghvi, H. Jiang, J. Zeng; J. Label. Compd Radiopharm. 2014, 57, 579-583.

148 a) S.A. Gerber, J. Rush, O. Stemman, M.W. Kirschner, S.P. Gygi, Proc Natl. Acad Sci 2003, 100, 6940-6945; b) A.N. Kettenbach, J. Rush, S.A. Gerber, Nat. Protoc. 2011, 6, 175-186; c) W.X. Schulze, B. Usadel Annu. Rev. Plant Biol. 2010, 61, 491-516.

149 a) P.H. Marathe, W.C. Shyu, W.G. Humphreys, Curr. Pharm. Des. 2004 10, 2991-3008; b) D. Dalvie, Curr. Pharm. Des. 2000, 6, 1009-1028; c) N. Penner, L.J. Klunk, C. Prakash, Biophram. Drug Dispos. 2009, 30 185-203; d) S.J. Roffey, R.S. Obach, J.I. Gedge, D.A, Smith, Drug Metab. Rev. 2007, 39, 17-43.

150 a) J. Iglesias, L. Sleno, D.A. Volmer, Curr. Drug Metab. 2012, 13, 1213 1225; b) C.J. Unkefer, R.A. Martinez, Drug Test. Analysis 2012, 4, 303 307.

151 a) A.E. Mutlib, S. Chen, J. Shockcor, R. Espina, S. Prakash, L. Gan, Chem. Res. Toxicol. 2002, 15, 63-75; b) S.D. Nelson, W.F. Trager Drug. Metab. Dispos. 2003, 31, 1481-1497; c) A.I. Iyer, B. Malhotra, S. Khan, J. Mitroka, S. Bonacorsi, S.C. Waller, J.K. Rinehart, K. Kripalani, Drug. Metab. Dispos. 2003, 31, 1481-1497.

152 a) T.A. Bailie, R. Halpin, B.K. Matuszewski, Drug Metab. Dispos. 2001 29 , 1614-1628; b) J Ni, J Rowe, T Heidelbaugh, S Sinha, A. Acheampong, Xenobiotica 2007, 37(2), 205-220.

153 a) K. Akira, E. Negishi, M. Imachi, T. Hashimoto, Drug Metab. Dispos. 2001, 29, 903-907; b) A.E. Mutlib, S. Chen, J. Shockcor, R. Espina, S. Prakash, L. Gan, Chem. Res. Toxicol. 2002, 15, 48-62.

154 a) D.Q. Liu, C.E.C.A. Hop, M.G. Beconi, A. Maio, S.-H.L. Chiu, Rapid Commun. Mass Spectrom. 2001, 15, 1832-1839; b) W. Lam, R Ramanathan, J. Am. Soc. Mass Spectrom. 2002, 13, 345-353; c) D.Q. Liu, C.E.C.A. Hop, J. Pharm. Biomed. Anal. 2005, 37(1), 1-18.

155 a) L.S. Busenlehner, R.N. Armstrong, Arch. Biochem. Biophys. 2005 433, 34-46; b) X. Yan, C.S. Maier, Methods Mol. Biol. 2009, 492, 255 271; c) J.R. Engen, Anal. Chem. 2009, 81(19), 7870-7875; d) L. Konermann, J. Pan, Y.H. Liu, Chem. Soc. Rev. 2011, 40, 1224-1234.

156 a) T. Ikeda, Curr. Med. Chem. 2015, 22, 528-537; b) A. F. Stepan, D.P. Walker, J. Baumann, D.A. Price, T.A. Baillie, A.S Kalgutkar, M.D. Aleo Chem. Res. Toxicol. 2011, 24, 1345-1410; c) R.S. Obach, A.S Kalgutkar J.R. Soglia, S.X. Zhao Chem. Res. Toxicol. 2008, 21, 1814 1822; d) L. Leung, A.S. Kalgutkar, R.S. Obach, Drug. Metab. Rev. 2012 44(1), 18-33. e) D.C. Evans, A.P. Watt, D.A. Nicoll-Griffith, T.A. Baillie, Chem. Res. Toxicol. 2004, 17, 3-16.

157 a) A. S. Kalgutkar, D. Dalvie, Ann. Rev. Pharm. Toxicol. 2015, 55, 35 a) A. S. Kalgutkar, D. Dalvie, Ann. Rev. Pharm. Toxicol. 2015, 55, 35
54 ; b) B.K. Park, A. Boobis, S. Clarke, C.E. Goldring, D. Jones, J. G Kenna, C. Lambert, H.G. Laverty, D.J. Naisbitt, S. Nelson, D.A. NicollGriffith, R.S. Obach, P. Routledge, D.A. Smith, D.J. Tweedie, N. Vermeulen, D.P. Williams, I.D. Wilson, T.A. Baillie, Nat. Rev. Drug Discov. 2011, 10, 292-306.

158 a) K. Huang, L. Huang, R. B. van Breemen, Anal. Chem. 2015, 87(7) 3646-3654. b) L. Ma, B. Wen, Q. Ruan, M. Zhu, Chem. Res. Toxicol 2008, 21(7), 1477-1483; c) Z. Yan, G.W. Caldwell, Anal. Chem. 2004 76(23), 6835-6847; d) Z. Yan, N. Maher, R. Torres, G. W. Caldwell, N. Huebert, Rapid Comm. Mass Spect. 2005, 19(22), 3322-3330; e) A Mutlib, W. Lam, J. Atherton, H. Chen, P. Galatsis, W. Stolle, Rapid Comm. Mass Spect. 2005, 19(23), 3482-3492; f) H.K. Lim, J. Chen, K. Cook, C. Sensenhauser, J. Silva, D.C. Evans, Rapid Comm. Mass Spect. 2008, 22, 1295-1311.

159 a) T. Yamaoka, Y. Kitamura, J. Pharm. Tox. Methods 2015, 76, 83-95; b) D. Defoy, P.M. Dansette, W. Neugebauer, J. R. Wagner, K. Klarskov, Chem Res. Toxicol 2011, 24(3), 412-417; c) Z Yan, N. Maher R. Torres, N. Huebert, Anal. Chem. 2007, 79, 4206-4214.

160 a) T. Rousu, O Pelkonen, Ari Tolonen, Rapid Comm. Mass Spect. 2009 23, 343-855; b) B. Wen, W.L. Fitch, Expert Opin. Drug Metab. Toxicol. 2009, 5, 39-55.
161 a) R. Aebersold, M. Mann, Nature, 2003, 422, 198-207; b) S. Plan, R. Aebersold, Methods Mol. Biol. 2007, 367, 209-218; c) L.V. Schneider M.H. Hall, Drug. Discov. Today 2005, 10, 353-363; d) K. Gevaert, F. Impens, B. Ghesquire, P. van Damme, A. Lambrechts, J. Vendekerckhove, Proteomics, 2008, 8, 4873-4885. e) S.E. Ong, M. Mann, Nat. Chem. Biol. 2005, 1, 252-262.

162 a) S. Sechi, Y. Oda, Curr. Opin. Biotechnol. 2003, 7, 70-77; b) M.B. Goshe, R.D. Smith, Curr. Opin. Biotechnol. 2003, 7, 101-109; c) B.J Cargile, J.L. Bundy, A.M. Grunden, J.L. Stephenson Jr., Anal. Chem. 2004, 76, 86-97.

163 a) S.P. Gygi, B. Rist, S.A. Gerber, F. Turecek, M.H. Gelb, R. Aebersold Nat. Biotechnol. 1999, 17, 994-999; b) W. A. Tao, R. Aebersold, Curr Opin. Biotechnol. 2003, 14, 110-118

164 a) Y. Shiio, R. Aebersold, Nat. Prot. 2006, 1, 139-145; b) A.S. Haqqani, J.F. Kelly, D.B. Stanimirovic, Methods Mol. Biol. 439, 225-240; c) A.S Haqqani, M. Nesic, E. Breston, E. Baumann, J.F. Kelly, D.B Stanimirovic, FASEB J, 2005, 19, 1809-1821.

165 O. Chahrour, D. Cobice, J. Malone, J. Pharm. Biomed. Anal. 2015, 113 2-20.

166 a) J. Li, H. Steen, S.P. Gygi, Mol. Cell. Proteomics 2003, 2, 1198-1204 b) J. Wu, Q. Lin, T.K. Lim, T. Liu, C.-L. Hew, J. Virol. 2007, 81, 11681 11689; c) J. Qu, W.J. Jusko, R.M. Straubinger, Anal. Chem. 2006, 78 4543-4552; d) J. Qu, R.M. Straubinger, Rapid Commun. Mass Spectrom. 2005, 19, 2857-2864.

167 a) A. Rainczuk, M. Condina, M. Pelzing, S. Dolman, J. Rao, N. Fairweather, T. Jobling, A.N. Stephens, J. Proteome Res. 2013, 12 4074-4088; b) G. Maccarrone, M. Lebar, D. Martins-de-Souza, Methods Mol. Biol. 2014, 1156, 175-185; c) F. Lottspeich, J. Kellermann Methods Mol. Biol. 2011, 753, 55-64; d) B. Leroy, C. Rosier, V. Erculisse, N. Leys, M. Mergeay, R. Wattiez, Proteomics 2010, 10 2281-2291.

168 P.J. Boersema, R. Raijmakers, S. Lemeer, S. Mohammed, A.J.R. Heck Nat. Prot. 2009, 4, 484-494.

a) B. Domon, R. Aebersold, Science 2006, 312, 212-217; b) A.-C Gingras, M. Gstaiger, B. Raught, R. Aebersold, Nat. Rev. Mol. Cell Biol. 2007, 8, 645-665.

170 a) G.C. McAlister, E.L. Huttlin, W. Haas, L. Ting, M.P. Jedrychowski, J.C. Rogers, K. Kuhn, I. Pike, R.A. Grothe, J.D. Blethrow, S.P. Gygi, Anal. Chem. 2012, 84, 7469-7478; b) T. Werner, I. Becher, G. Sweetman, C. Doce, M.M. Savitski, M. Bantscheff, Anal. Chem. 2012, 84, 7188-7194.

171 a) S.Y. Ow, M. Salim, J. Noirel, C. Evans, I. Rehman, P.C. Wright, J. Proteome Res. 2009, 8, 5347-5355; P.L. Ross, Y.N. Huang, J.N. Marchese, B. Williamson, K. Parker, S. Hattan, N.Khainovski, S. Pillai, S. Dey, S. Daniels, S. Purkayastha, P. Juhasz, S. Martin, M. BartletJones, F. He, A. Jacobson, D.J. Pappin, Mol. Cell. Proteomics 2004, 3 1154-1169; d) L. Choe, M. D’Ascenzo, N.R. Relkin, D. Pappin, P. Ross B. Williamson, S. Guertin, P. Pribil, K.H. Lee, Proteomics 2007, 7 3651-3660.

a) C.J. Koehler, M. Strozynski, F. Kozielski, A. Treumann, B. Thiede, J. Proteome Res. 2009, 8, 4333-4341; b) M. Ø Arntzen, C.J. Koehler, A Treumann, B. Thiede, Methods Mol. Biol. 2011, 753 65-76; c) C.J. Koehler, M. $\varnothing$ Arntzen, M. Strozynski, A. Treumann, B. Thiede, Anal. Chem. 2011, 83, 4775-4781.

a) S.E. Ong, B. Blagoeev, I. Kratchmarova, D.B. Kristensen, H. Stehen A. Pandey, M. Mann, Mol. Cell. Proteomics 2002, 1, 376-386; b) M. Mann, Nat. Rev. Mol. Cell. Biol. 2006, 7, 952-958.

174 a) H.C. Harsha, H. Molina, A. Pandey, Nat. Prot. 2008, 3(3), 505-516; b) S.E. Ong, M. Mann, Nat. Protoc. 2008, 1(6), 2650-2660

175 M. Selbach, M. Mann, Nat. Met. 2006, 3, 981-983.

176 A. Sirvent, O. Vigy, B. Orsetti, S. Urbach, S. Roche, Mol. Cell. Proteomics 2012, 11(12), 1937-1950.

177 a) C.C. Wu, M.J. MacCoss, K.E. Howell, D.E. Matthews, J.R. Yates III. Anal. Chem. 2004, 76, 4951-4959; b) D.B. McClatchy, M.Q. Dong, C.C. Wu, J.D. Venable, J.R. Yates III., J. Proteome Res, 2007, 6, 2005-2010. 178 N. Rauniyar, D.B. McClatchy, J.R. Yates III, Methods, 2013, 61, 260 168.

179 a) A.J. Claydon, M.D. Thom, J.H. Hurst, R.J. Beynon, Proteomics, 2012 12, 1194-1206; b) A.J. Claydon, R.J. Beynon, Methods. Mol. Biol. 2011, 759, 179-195;

180 M.K. Doherty, D.E. Hammond, M.J. Clague, S.J. Gaskell, R.J. Beynon, J. Proteome Res. 2009, 8, 104-112.

181 a) A.F.M. Altelaar, J. Munoz, A.J.R. Heck, Nat. Rev. 2013, 14, 35-48; b) I.V. Hinkson, J.E. Elias, Trends Cell. Biol. 2011, 21(5), 293-303.

182 a) J.C. Price, W.E. Holmes, K.W. Li, N.A. Floreani, R.A. Neese, S. M Turner, M.K. Hellerstein, Anal. Biochem. 2012, 420, 73-83; b) T. Kasumov, S. Ilchenko, L. Li, N. Rachdaoui, R.G. Sadygov, B. Willard, A.J. McGullough, S. Previs, Anal. Biochem. 2011, 412, 47-55.

183 a) W.B. Silva, D.M. Daloso, A.R. Fernie, A. Nunes-Nesi, W.L. Araujo Plant Science 2016, 249, 59-69; b) D. Weindl, A. Wegner, K. Hiller, Front. Physiol. 2015, 6, 344; c) D.J. Creek, Bioanalysis 2013, 5(15) 1807-1810; d) C. Bueschl, D. Krska, B. Kluger, R. Schuhmacher, Anal. Bioanal. Chem. 2013, 405, 27-33

184 a) J. Castro-Perez, S.F. Previs, D.G. Mclaren J. Lipid Res. 2011, 52(1), 159-169, b) E. Heinzle, F. Matsuda, H. Miyagawa, K. Wakasa, T. Nishioka, Plant J. 2007, 50, 176-187. 
185 a) R. Hoekstra, G.A Nibourg, T.V van der Hoeven, M.T. Ackermans, T.B. Hakvoort, T.M. van Gulik, W.H. Lamers, R. Elferink, R.A Chamuleau, Int. J. Biochem. Cell Biol. 2011, 43, 1483-1489; b) D. Mavri-Damelin, L.H. Damelin, S. Eaton, M. Rees, C. Selden, H.J. Hodgson, Biotechnol. Bioeng. 2008, 99, 644-651.

186 a) A. Chokkathukalam, D.-H. Kim, M.P. Barrett, R. Breitling, D.J. Creek Bioanalysis 2014, 6(4), 511-524; b) T.W.-M. Fan, P.K. Lorkiewicz, K Sellers, H.N.B. Moseley, R.M. Higashi, A.N. Lane, Pharmacol. Ther 2012, 133, 366-391.

187 a) W.B. Dunn, A. Erban, R.J.M. Weber, D.J. Creek, M. Brown, R. Breitling, T. Hankemeier, R. Goodacre, S. Neumann, J. Kopka, M.R. Viant, Metabolomics 2013, 9(1), 44-66; b) W.B. Dunn, D.I. Broadhurst H.J. Atherton, R. Goodacre, J.L. Griffin, Chem. Soc. Rev. 2011, 40(1) 387-426; b) D.S. Wishart, Bioanalysis 2011, 3(15), 1769-1782.

188 a) B.D. Bennett, J. Yuan, E.H. Kimball, J.D. Rabinowitz, Nat. Prot. 2008 3(8), 1299-1311; b) C. Bueschl, R. Krska, B. Kluger, R. Schuhmacher Anal. Bioanal. Chem. 2012, 405(1), 27-33; c) P. Giavalisco, J. Hummel, J. Lisec, A.C. Inostroza, G. Catchpole, L. Willmitzer, Anal. Chem. 2008 80(24), 9417-9425.

189 a) P. Giavalisco, K. Koehl, J. Hummel, B. Seiwert, L. Willmitzer, Anal Chem. 2009, 81(15), 6546-6551; b) A.D. Hegeman, C.F. Schulte, Q. Cui, I.A. Lewis, E.L. Huttlin, H. Eghbalnia, Anal. Chem. 2007, 79(18), 6912-6921.

190 O. Vielhauer, M. Zakhartsev, T. Horn, R. Takors, M. Reuss, J. Chromatogr. B 2011, 879(32), 3859-3870.

191 a) T. Toyo'oka, J. Pharm. Biomed. Anal. 2012, 69, 174-184; b) P. Bruheimer, H.F.N. Kvitvang, S.G. Villas-Boas, J. Chromatogr. A 2013 1296, 196-203; c) S. Szarka, K. Prokai-Tetrai, L. Prokai, Anal. Chem. 2014, 86, 7033-7040

192 a) W. Yuan, K.W. Anderson, S. Li, J.L. Edwards, Anal. Chem. 2012 84(6), 2892-2899; b) D. Zeng, S. Li, Chem. Commun. 2009, 3369-3371; c) J. Zhang, Y. Wang, S. Li, Anal. Chem. 2010, 82, 7588-7595.

193 D.W. Johnson, J. Chromatogr. B 2011, 879, 1345-1352.

194 K. Shimbo, A. Yahashi, K. Hirayama, M. Nakazawa, H. Miyano, Anal Chem. 2009, 81, 5172-5179.

K. Guo, C. Ji, L. Li, Anal. Chem. 2007, 79(22), 8631-8638.

196 a) P. Kang, Y. Mechref, Z. Kyselova, J.A. Goetz, M.V. Novotny, Anal. Chem. 2007, 79(16), 6064- 6073; b) J.A. Atwood, L. Cheng, G. AlvarezManilla, N.L. Warren, W.S. York, R. Orlando, J. Proteome Res. 2008, 7 , 367-374.

197 K. Guo, L. Li, Anal. Chem. 2009, 81(10), 3919-3932.

198 K. Guo, L. Li, Anal. Chem. 2010, 82(21), 8789-8793.

199 W.C. Yang, J. Adamec, F.E. Regnier, Anal. Chem. 2007, 79, 5150 5157

200 a) D. Herebian, B. Hanisch, F.J. Marner, Metabolomics 2005,1, 317 324; b) S.K. Lien, H.F.N. Kvitvang, P. Bruheim, J. Chromatogr. A 2012 $1247,118-124$

201 X.D. Huang, F.E. Regnier, Anal. Chem. 2008, 80, 107-114

202 H.F.N. Kvitvang, T. Andreassen, T. Adam, S.G. Villas-Boas, P. Bruheim, Anal. Chem. 2011, 83, 2705-2711.

203 a) D.J. Creek, A. Chokkathukalam, A. Jankevics, K.E.V. Burgess, R Breitling, M.P. Barrett, Anal. Chem. 2012, 84(20), 8442-8447; b) R. Peyraud, P. Kiefer, P. Christen, S. Massou, J.-C. Portais, J.A. Vorholt, Proc. Natl Acad Sci. USA 2009, 106(12) 4846-4851; c) P.M. Cano, E.L. Jamin, S. Tadrist, Anal. Chem. 2013, 85(17), 8412-8420

204 a) D. Müller, E. Heinzle, Curr. Opin. Biotechnol. 2013, 24, 54-59; b)

205 J.M. Buescher, M.R. Antoniewicz, L.G. Boros, S.C. Burgess, H. Brunengraber, C.B. Clish, Curr. Opin. Biotechnol. 2015, 34, 189-201.

206 A) M.R. Atoniewicz, Curr. Opin. Biotechnol. 2013, 24, 48-53; b) J.D. Young, D.K. Allen, J.A. Morgan, Methods Mol. Biol. 2014, 1083, 85 108; c) Q.X. Truong, J.M. Yoon, J.V. Shanks, Methods Mol. Biol. 2014 1083, 65-83

207 U. Sauer, Mol. Syst. Biol. 2006, 2, 62

208 a) L. You, B. Zhang, Y.J. Tang, Metabolites, 2014, 4, 142-165; b) J.K. a) L. You, B. Zhang, Y.J. Tang, Metabolites, 2014, 4, 142-165; b) J.K.2680.

209 A. Wegner, J. Meiser, D. Weindl, K. Hiller, Curr. Opin. Biotechnol. 2015 , 34, 16-22.

210 a) K. Hiller, C. Metallo, G. Stephanopoulos, Curr. Pharm. Biotechnol. 2011, 12, 1075-1086; b) L.E. Quek, S. Dietmair, J.O. Kromer, L.K Nielsen, Metab. Eng. 2010, 12, 161-171; c) M. Kohlstedt, J. Becker, C Wittmann, Appl. Microbiol. Biotechnol. 2010, 88, 1065-1075.

211 a) J. Niklas, K. Schneider, E. Heinzle, Curr. Opin. Biotechnol. 2010, 21, 63-69; b) W.S. Ahn, M.R. Antoniewicz, Biotechnol. J. 2012, 7, 61-74.

212 S.M. Turner, J. Pharmacol. Toxicol. Methods 2006, 53, 75-85

213 a) S. Klein, E. Heinzle, Rev. Syst. Biol. Med. 2012, 4, 261-272; b) F. Chiaradonna, R.M. Moresco, C. Airoldi, D. Gaglio, R. Palorini, F. Nicotra, C. Messa, L. Alberghina, Biotechnol. Adv. 2012, 30, 30-51; c) K. Hiller, C.M. Metallo, J.K. Kelleher, G. Stephanopoulos, Anal. Chem. 2010, 82(15), 6621-6628.

214 a) M.R. Antoniewicz, D.F. Kraynie, L.A. Laffend, J. Gonzalez-Lergier J.K. Kelleher, G. Stephanopoulos, Metab. Eng. 2007, 9, 277-292; b) N.J. Kruger, S.K. Masakapalli, R.G. Ratcliffe, J. Exp. Bot. 2012, 63 2309-2323.

215 T. Fan, A. Lane, R. Higashi, Mol. Cancer 2009, 8(1), 41.
216 R.A. Scheltema, A Jankevics, R.C. Jansen, M.A. Swertz, R. Breitling Anal. Chem. 2011, 83(7), 2786-2793.

217 R.C.A. Schellekens, F. Stellard, H.J. Woerdenbag, H.W. Frijlink, J.G.W Kosterink, Br. J. Clin. Pharmacol. 2011, 72(6), 879-897.

218 a) S.K. Peng, K.J. Ho, C.B. Taylor, Arch. Pathol. 1972, 94, 81-89; b) P.D. Klein, E.R. Klein, J. Clin. Pharmacol. 1986, 26, 378-382.

219 a) M.K. Hellerstein, R.A. Hoh, M.B. Hanley, D. Cesar, D. Lee, R.A Neese, J.M. McCune, J. Clin. Invest. 2003, 112, 956-966; b) R.A Neese, L.M. Misell, S. Turner, A. Chu, J. Kim, D. Cesar, R. Hoh, F. Antelo, A. Strawford, J.M. McCune, M. Christiansen, M.K. Hellerstein Proc. Natl. Acad. Sci. U. S. A. 2002, 99, 15345-15350.

220 a) M.L. Collins, S. Eng, R. Hoh, M.K. Hellerstein, J. Appl. Physiol. 2003 94, 2203-2211; b) P.J. Jones, S.T. Leatherdale, Clin. Sci. (Lond.) 1991 $80,277-280$

221 T. Strekalova, M. Evans, A. Chernopiatko, Y. Couch, J. Costa-Nunes, R. Cespuglio, L. Chesson, J. Vignisse, H.W. Steinbusch, D.C. Anthony, I. Pomytkin, K.-P. Lesch, Behav. Brain Res. 2015, 277, 237-244.

222 a) H. Shimamoto, S. Komiya, J. Physiol. Anthropol. Appl. Hum. Sci. 2003, 22, 311-315; b) A. Raman, D.A. Schoeller, A.F. Subar, R.P. Troiano, A. Schatzkin, T. Harris, D. Bauer, S.A. Bingham, J.E. Everhart, A.B. Newman, F.A. Tylavsky, Am. J. Physiol.: Renal. Physiol. 2003 286, F394-F401; c) B.T. Messmer, D. Messmer, S.L. Allen, J.E. Kolitz, P. Kudalkar, D. Cesar, E.J. Murphy, P. Koduru, M. Ferrarini, S. Zupo, G. Cutrona, R.N. Damle, T. Wasil, K.R. Rai, M.K. Hellerstein, N. Chiorazzi, J. Clin. Invest. 2005, 115, 755-764.

223 a) R. Busch, Y.-K. Kim, R.A. Neese, V. Schade-Serin, M. Collins, M Awada, J.L. Gardner, C. Beysen, M.E. Marino, L.M. Misell, M.K Hellerstein, Biochim. Biophys. Acta 2006, 1760, 730-744; b) D.A Dufner, I.R. Bederman, D.Z. Brunengraber, N. Rachdaoui, F. Ismail Beigi, B.A. Siegfried, S.R. Kimball, S.F. Previs, Am. J. Physiol. Endocrinol. Metab. 2005, 288, E1277-1283.

224 T. Kasumov, B. Willard, L. Li, R.G. Sadygov, S. Previs, Proteome Dynamics with Heavy Water - Instrumentations, Data Analysis, and Biological Applications, Recent Advances in Proteomics Research Sameh Magdeldin (Ed.), InTech., 2015.

225 H.G. Gasier, J.D. Fluckey, S.F. Previs Nutrit. Metab. 2010, 7, 31

226 I.R. Bederman, S. Foy, V. Chandramouli, J.C. Alexander, S.F. Previs, J. Biol. Chem. 2009, 284, 6100-6108.

227 J. Katnik, B.J. McCabe, D.Z. Brunengraber, V. Chandramouli, F.J. Nishiyama, V.E. Anderson, S.F. Previs, Am. J. Physiol. Endocrinol. Metab. 2003, 284, E1043-1048.

228 a) D. Dufner, S.F. Previs, Curr. Opin. Clin. Nutr. Metab. Care 2003, 6 511-517; b) E.C. Rush, P. Chhichhia, A.E. Kilding, L.D. Plank Eur. J Appl. Physiol. 2010, 110(6), 1209-1214.

229 a) J.N. Voogt, M. Awanda, E.J. Murphy, G.M. Hayes, R. Busch, M.K Hellerstein, Nat. Protoc. 2007, 2, 3058-3062; b) R. Busch, R.A. Neese M. Awanda, G.M. Hayes, M.K. Hellerstein, Nat. Protoc. 2007, 2, 3045 3057

230 E.S. Jin, J.G. Jones, M. Merritt, S.C. Burgess, C.R. Malloy, A.D. Sherry Anal. Biochem. 2004, 327, 149-155.

a) A. Avogaro, J.D. Bristow, D.M. Bier, C. Cobelli, G. Toffolo, Diabetes 1989, 38, 1048-1055; b) R. Hovorka, P. Bannister, D.J.A. Eckland, D. Halliday, D.N. Murley, S.E. Rees, M.A. Young, Diabetic Med. 1998, 15 234-246.

a) R.J. Bateman, L.Y. Munsell, J.C. Morris, R. Swarm, K.E Yarasheski, D.M. Holtzman, Nat. Med. 2006, 12, 856-861; b) K.G. Mawuenyega, T. Kasten, W. Sigurdson, R.J. Bateman, Anal. Biochem. 2013, 440, 56-62.

233 M. Di Buono, P.J.H. Jones, L. Beaumier, L.J. Wykes, J. Lipid Res. 2000 41, 1516-1523.

234 a) J. Ecker, G. Liebisch, Prog. Lipid Res. 2014, 54, 14-31; b) E.J. Park M.K. Hellerstein, J. Lipid Res. 2006, 47, 1651-1660.

235 a) J. Ecker, G. Liebisch, M. Englmaier, M. Grandl, H. Robenek, G. Schmitz, Proc. Natl. Acad Sci. USA 2010, 107, 7817-22; b) J.M. Collins, M.J. Neville, K.E. Pinnick, L. Hodson, B. Ruyter, T.H. van Dijk, J. Lipid Res. 2011, 52, 1683-1692.

236 a) J.J. Kamphorst, J. Fan, W. Lu, E. White, J.D. Rabinowitz, Liquid Anal. Chem. 2011, 83, 9114-9122; b) P.M. Le, C. Fraser, G. Gardner, W.W Liang, J.A. Kralovec, S.C. Cunnane, Anal. Bioanal. Chem. 2007, 389 , 241-249.

237 M.D. Bruss, C.F. Khambatta, M.A. Ruby, I. Aggarwal, M.K. Hellerstein Am. J. Physiol. Endocrinol. Metab. 2010, 298, E108-E116.

238 D.G. McLaren, T. He, S.P. Wang, V. Mendoza, R. Rosa, K. Gagen, J. Lipid Res. 2011, 52, 1150-1161.

239 R.J. Pawlosky, J.R. Hibbeln, N. Salem Jr, J. Lipid Res. 2007, 48, 935943.

240 R.J. Pawlosky, J.R. Hibbeln, Y. Lin, S. Goodson, P. Riggs, N. Sebring Am. J. Clin. Nutr. 2003, 77, 565-572.

241 a) B. Fielding, Proc. Nutr. Soc. 2011, 70, 342-350; b) X.M. Persson, A.U. Blachnio-Zabielska, M.D. Jensen, J. Lipid Res. 2010, 51, 2761 2765; c) A.S. Bickerton, R. Roberts, B.A. Fielding, L. Hodson, E.E. Blaak, A.J. Wagenmakers, Diabetes 2007, 56, 168-76.

242 a) P.E. Cogo, A. Gucciardi, U. Traldi, A.W. Hilkert, G. Verlato, V. Carnielli, J. Mass Spectrom. 2005, 40, 876-881; b) L. Vedovelli, A Baritussio, V.P. Carnielli, M. Simonato, P. Giusti, P.E. Cogo J. Mass Spectrom. 2011, 46, 986-992; c) D.G. McLaren, S.P. Wang, S.J. Stout, D. Xie, P.L. Miller, V. Mendoza, J. Lipid Res. 2013, 54, 276-281. 
A.D Postle, A.N Hunt, J Chromatogr B. 2009, 877, 2716-2711. V.P. Carnielli, L.J. Zimmermann, A. Hamvas, P.E. Cogo, J. Perinatol. 2009, 29(Suppl. 2), S29-S37.

245 A.U. Blachnio-Zabielska, X.M. Persson, C. Koutsari, P. Zabielski, M.D. Jensen, Rapid Commun. Mass Spectrom. 2012, 26, 1134-1140.

246 a) C.J. DeLong, Y.J. Shen, M.J. Thomas, Z.Cui, J. Biol. Chem. 1999 274, 29683-29688; b) W. Bernhard, C.J. Pynn, A. Jaworski, G.A. Rau J.M. Hohlfeld, J. Freihorst, Am. J. Respir. Crit. Care Med. 2004, 170 54-58; b) C.J. Pynn, N.G. Henderson, H. Clark, G. Koster, W. Bernhard A.D. Postle, J. Lipid Res. 2011, 52, 399-407.

247 G. Lappin, M. Rowland, R.C. Garner, Expert Opin. Drug Metab. Toxicol. 2006, 2(3), 419-427

248 A. Parr, G. Badman, C.L. Bowen, M. Coffin, M. Gupta, L. Jones, M. Kurtinecz, O Naderer, E. Travis, J Zhu, P. Patel, J Clin. Pharmacol. 2015, 56(7), 801-805.

249 a) R.C.A. Schellekens, F. Stellaard, D. Mitrovic, F.E. Stuurman, J.G.W Kosterink, H.W. Frijlink, J. Control Release 2008, 132, 91-98; b) R.C.A Schellekens, F. Stellaard, G.G. Olsder, H.J. Woerdenbag, H.W. Frijlink J.G.W. Kosterink, J. Control Release 2010, 146, 334-340; c) R.C.A Schellekens, G.G. Olsder, SMCH Langenberg, T. Boer, H.J. Woerdenbag, H.W. Frijlink, J.G.W. Kosterink, F. Stellaard Br. J. Pharmacol. 2009, 158, 532-540.

250 a) I.R. Schultz, R.E. Shangraw, Toxicol. Sciences 2006, 92(1), 42-50 b) A.K. Majumdar, L. Howard, M.R. Goldberg, L. Hickey, M Constanzer, P.L. Rothenberg, T.M. Crumley, D. Panebianco, T.E. Bradstreet, A.J. Bergman, S.A. Waldman, H.E. Greenberg, K. Butler, A Knops, I. De Lepeleire, N. Michiels, K.J. Petty, J. Clin. Pharmacol. 2006, 46, 291-300; c) D.J.R. Foster, E.B. Morton, G. Heinkele, T.E. Mürdter, A.A. Smogyi, Ther. Drug Monit. 2006, 28, 559-567.

251 a) G. Lappin, R. Noveck, T. Burt, Expert Opin. Drug Metab. Toxicol. 2013, 9(7), 817-834; b) G. Lappin, C.C. Wagner, O. Langer, N. van de Merbel, Bioanalysis 2009, 1(2), 357-366; c) Y. Sugiyama, S. Yamashita Adv. Drug. Deliv. Rev. 2011, 63, 494-502; d) G. Lappin, Bioanalysis 2010, 2(3), 509-517; e) M. Rowland, Bioanalysis 2010, 2(3), 385-391.

252 a) H. Gu, J. Wang, A.F. Aubry, H. Jiang, J. Zeng, J. Easter, J.S. Wang, R. Dockens, M. Bifano, R. Burrell, M.E. Arnold. Anal. Chem. 2012, 84, 4844-4850; b) H. Jiang, J. Zeng, W. Li, M. Bifano, H. Gu, C. Titsch, J. Easter, R. Burell, H. Kandoussi, A.-F. Aubry, M.E. Arnold, Anal. Chem 2012, 84, 10031-10037; c) R. de Vries, J.W. Smit, P. Hellemans, J. Jiao, J. Murphy, D. Skee, J. Snoeys, J. Sukbuntherng, M. Vliegen, L. de Zwart, E. Mannaert, J. de Jong, Br. J. Clin. Pharmacol. 2015, 1-11; d) E.A. Cannady, A. Aburub, C. Ward, C. Hinds, B. Czeskis, K Ruterbories, J-G. Suico, J. Royalty, D. Ortega, B.W. Pack, S.L. Begum, W.F. Annes, Q Lin, D.S. Smalla, J. Label Compd. Radiopharm. 2016 DOI: 10.1002/jlcr.3358

$253 \quad \mathrm{CH}$ guideline M3(R2) Non-clinical safety studies for the conduct of human clinical trials and marketing authorisation for pharmaceuticals 2009

254 a) D.W Boulton, S. Kasichayanula, C.F. Keung, M.E Arnold, L.J. Christopher, X. Xu, F. LaCreta Br. J. Clin. Pharmacol. 2013, 75(3), 763 768; b) A. Arjomand, Bioanalysis 2010, 2(3), 519-541; D. Higton, M Seymour, Bioanalysis 2014 6(5), 665-672.

255 D. Schwab, A. Potron, Z. Backholer, B. Lausecker, K. Kawashima, Clin Pharmacokinet. 2013, 52, 463-473.

256 G.S. Timmins, Expert Opin. Ther. Patents, 2016, 27, 1393-1398

257 a) L. Bonfrate, I. Grattagliano, G. Palasciano, P. Portincasa Gastroenterol. Rep. 2015, 3(1), 12-21; b) B. Braden, B. Lembcke, W. Kukera, W.F. Caspary, Dig. Liver Dis. 2007, 39, 795-805; c) B. Braden, Best Pract. Res. Clin. Gastroent. 2009, 23, 337-352

258 I. Grattagliano, B.H. Lauterburg, G. Palasciano, Eur. J. Clin. Invest 2010, 40, 843-850.

259 b) B. Riecke, P. Neuhaus, M. Stockmann, Helicobacter, 2005, 10(6), 620-622.

260 a) T.A. Di Rienzo, G. D’Angelo, V. Ojetti, M.C. Campanala, A. Tortora V. Cesario, G. Zuccala, F. Franceschi, Eur. Rev. Med. Pharmacol. Sci. 2013; 17(2), 51-58 b) A. Maity, S. Som, C. Ghosh, G.D. Banik, S.B. Daschakraborty, S.Ghosh, S Chaudhurib, M. Pradhan, J. Anal. At Spectrom. 2014, 29, 2251-2255; c) L. Gatta, C. Ricci, A. Tampieri, Gut 2006, 55(4), 457-462.

261 a) F. Perri, M. Bellini, P. Portincasa, Dig. Liver Dis. 2010, 42, 549-53 b) L. Bonfrate, V. Ruggiero, E Mossel, Eur J. Clin Invest 2014, 44, 78 ; c) L.A. Szarka, M. Camilleri, A. Vella, Clin. Gastroenterol Hepatol. 2008, 6, 635-643.

262 a) Y. Ishii, T. Kohno, A. Ito, Pancreas 2007, 35(4), 313-319; b) M.A Ritz, R.J. Fraser, A.C. Di Matteo, J. Gastroenterol. Hepatol. 200, 19(4) 448-453.

263 a) A. Rocco, G. de Nucci, G. Valente J. Hepatol. 2012, 56, 782-787; b) M. Banasch, M. Ellrichmann, A. Tannapfel, Eur. J. Med. Res. 2011, 16 , 258-264; c) T. Shalev, H. Aeed, V. Sorin, Dig. Dis. Sci. 2010, 55, 1589 98.

264 R. Roberts, A.S. Bickerton, B.A. Fielding, Am. J. Clin. Nutr. 2008, 87(4), 824-831.

265 a) M. Elsner, M. A. Jochmann, T.B. Hofstetter, D Hunkeler, A Bernstein T.C. Schmidt, A. Schimmelmann, Anal. Bioanal. Chem. 2012, 403(9) 2471-2491; b) M. Thullner, F. Centler, H.-H. Richnow, A. Fischer, Org. Geochem. 2012, 42(12), 1440-1460.
266 a) M. Elsner, J Environ Monit 2010, 12 2005-2031; b) U Jaeckel, C Vogt, A. Fischer, H.-H. Richnow, F. Musat, Environ. Microbiol. 2014 16(1), 130-140; c) S. Kümmel, R. Starke, G. Chen, F. Musat, H.-H. Richnow, C. Vogt, Environ. Sci. Technol. 2016, 50(6), 3091-3100; d) G. Imfeld, F.-D. Kopinke, A. Fischer, H.-H. Richnow, Chemosphere 2014 107, 454-461.

267 a) S. Radajewski, P. Ineson, N.R. Parekh, J.C. Murrell, Nature, 2000 403, 646-649; b) M.G. Dumont, J.G. Murrell Nat. Rev. Microbiol. 2005 3, 499-504; c) Y. Chen, J.C. Murrell, Trends Microbiol. 2010, 18, 157 163. E.L Madsen in Stable isotope probing and related technologies edited by J.C. Murrell, A. Whiteley, Washington DC, ASM Press, 2010, p. $165-202$

268 a) O. Uhlík, K. Ječná, M. Macková, C. Vlček, M. Hroudová, K Demnerová, Appl. Environ. Microbiol. 2009, 75, 6471-6477; b) F.Z. Haichar, T. Heulin, J.P. Guyonnet, W. Achouak, Curr. Opin. Biotechnol. 2016, 41, 9-13.

269 a) T.H. Bell, E. Yergeau, C. Martineau, D. Juck, L.G. Whyte, C.W Greer, Appl. Environ. Microbiol 2011, $77,4163-4171$; b) H. Roh, C.P. Yu, M.E. Fuller, K.H. Chu, Environ. Sci. Technol. 2009, 43, 2505-2011 c) D.H. Buckley, V. Huangyutitham, S.F. Hsu, T.A. Nelson, Appl. Environ. Microbiol. 2007, 73, 3196-3204.

270 a) M. Kästner, K.N. nowak, A. Miltner, A. Schäfer, Curr. Opin Biotechnol. 2016, 41, 73-82; b) Z.T. Aanderud, J.T. Lennon, Appl. Environ. Microbiol. 2011, 77, 4589-4596.

271 a) A. Fischer, M. Manefield, P. Bombach, Curr. Opin. Biotechnol. 2016 41, 99-107; b) O. Uhlík, M.-C. Leewis, M. Strejcek, L. Musliva, M. Mackova, M.B. Leigh, T. Macek, Biotech. Adv. 2013, 31, 154-165.

272 H.T.S. Boschker, S.C. Nold, P. Wellsbury, D. Bos, W. de Graaf, R. Pel, Nature; 1998, 392, 801-805.

273 J.D. Neufeld, J. Vohra, M.G. Dumont, T. Lueders, M. Manefield, M.W Friedrich, Nat. Prot. 2007, 2, 860-866.

a) T. Lueders, M.G. Dumont, L. Bradford, M. Manefield, Curr. Opin Biotechol. 2016, 41, 83-89; b) M.G. Dumont, B. Pommerenke, P. Casper, R. Conrad. Environ. Microbiol. 2011, 13, 1153-1167.

a) N. Jehmlich, C. Vogt, V. Lünsmann, H.H. Richnow, M. von Bergen, Curr. Opin. Biotechnol. 2016, 41, 26-33; b) N. Jehmlich, F. Schmidt, M. Taubert, J. Seifert, F. Bastida, M. von Bergen, H.H. Richnow, C. Vogt, Nat. Prot. 2010, 5, 1957-1966.

a) Wikipedia, the free encyclopaedia; b) U.S. Department of Energy, DOE Handbook: Tritium Handling and Safe Storage, DOE-HDBK-1129 2007, March 2007; c) Health Physics Society, Tritium Fact Sheet, March 2011.

277 M. Saljoughian, P.G. Williams, Curr. Pharm. Des. 2000, 6, 1029-1056.

278 a) A. Damont, S. Garcia-Argote, D.-A. Buisson, B. Rousseau, F. Dolléa J. Label Compd Radiopharm. 2015, 58, 1-6; b) G. Tóth J.R. Mallareddy, F. Tóth, A. W. Lipkowski, D. Tourwéc, ARKIVOC 2012, (v) 163-174; c) U.S. Larsen, H.B. Hansen, A.-M. Dahl, L. Sörensen, J.B. Kristensen, J. Label. Compd. Radiopharm. 2007, 50, 549-550.

279 U. Pleiss, J. Label. Compd Radiopharm. 2003 , 46, 1241-1247. a) D. Hesk, P. McNamara, J. Label. Compd. Radiopharm. 2007, 50, 875-887; b) M. Saljoughian, Synthesis 2002, 13, 1781-1801. J.A. Krauser, J. Label Compd. Radiopharm. 2013, 56, 441-446. a) P. Hein, M.C. Michel, K. Leineweber, T. Wieland, N. Wettschureck, S. Offermanns, Receptor and binding studies, in: Practical Methods in Cardiovascular Research, S. Dhein, F. Mohr, M. Delmar (Eds.) Springer, Berlin Heidelberg, 2005, 723-783; b) M. McKinney, R Raddatz, Curr. Prot. Pharmacol. 2006, 33, 1.3.1-1.3.42.

283 J.J. Maguire, R.E. Kuc, A.P. Davenport, Methods Mol. Biol. 2012, 897, 31-77.

284 E.C. Hulme, M.A. Trevethick, Br. J. Pharmacol. 2010, 161, 1219-1237.

285 a) S.D. Kahl, C. C. Felder, Curr. Protoc. Neurosci. 2005, 30, 7.15.1 7.15 .50 ; b) N. Bosworth, P. Towers, Nature 1989, 341, 167-168; c) S. Udenfriend, L Gerber, N. Nelson, Anal. Biochem 1987, 161, 494-500.

286 a) D. Harder, D. Fotiadis, Nat. Prot. 2012, 7(9), 1569-1578; b) J. Berry, M. Price-Jones, B. Killian, Methods Mol. Biol. 2012, 897, 79-94.

287 a) J.F. Glickman, A. Schmid, S. Ferrand, Assay Drug Dev. Technol. 2008, 6, 433-455; b) S. Wu, B. Liu, BioDrugs 2005, 19, 383-392. a) M. Quick, J.A. Javitch, Proc. Natl. Acad. Sci. USA 2007, 104, 3603 3608; b) J.-M. Jeckelmann, D. Harder, S.A. Mari, M. Meury, Z. Ucurum, D.J. Müller, B. Erni, D. Fotiadis, J. Struct. Biol. 2011, 176, 395-403; c) F. Lu, S. Li, Y. Jiang, J. Jiang, H. Fan, G. Lu, D. Deng, S. Dang, X. Zhang, J. Wang. N. Yan, Nature 2011, 472, 243-246; d) M. Quick, L. Shi, B. Zehnpfennig, H. Weinstein, J.A. Javitch, Nat. Struct. Mol. Biol. 2012 19, 207-211; e) Z. Zhou, J. Zhen, N.K. Karpowich, R.M. Goetz, C.J. Law, M.E.A. Reith, D.-N. Wang, Science 2007, 317, 1390-1393.

289 a) K.J. Dillon, G.C.M. Smith, N.M.B. Martin, J. Biomol. Screen. 2003 8(3), 347-352; b) B. A. Brown, M. Cain, J. Broadbent, S. Tompkins, G Henrich, R. Joseph, S. Casto, H. Harney, R. Greene, R. Delmondo, FlashPlate technology, in High Throughput Screening: the Discovery of Bioactive Substances, J.P. Devlin, ed. (New York: Marcel Dekker, Inc.) 1997, 317-328.

290 a) V. Stepanova, M. Schou, J. Järva, C. Halldin, Appl. Radiat. Isot 2007, 65, 293-300; b) S. Hintermann, I. Vranesic, H. Allgeier, A Brülisauer, D. Hoyer, M. Lamaire, T. Moenius, S. Urwyler, S. Whitebread, F. Gasparini, Y.P. Auberson, Bioorg. Med. Chem. 2007, 15, 903-914. 
291 a) C.C. Wagner, O. Langer, Adv. Drug. Deliv. Rev. 2011, 63, 539-546; b) Y. Sugiyama, S. Yamashita, Adv. Drug. Deliv. Rev. 2011, 63, 494 502; c) S. Gross, D. Piwnica-Worms, Curr. Opin. Chem. Biol. 2006, 10 , 334-342.

292 a) Z.-M. Yang, Q.-F.u Ye, L. Lu, J. Label. Compd. Radiopharm. 2008 51, 182-186 ; C. Li, X.-Y. Xu, J.-Y. Li, Q.-F. Ye, Z. Li, J. Label. Compd. Radiopharm. 2011, 54, 256-259.

293 B. Schäfer, E. Orbán, Z. Kele, C. Tömbölya, J. Label. Compd. Radiopharm. 2015, 58, 7-13.

294 B. Catalgol, T. Grune, Free Radic. Biol. Med. 2009, 46, 8-13.

295 a) I. Horiuchi, T. Nozawa, N. Fujii, H. Inoue, M. Honda, T. Shimizu, M. Taguchi, Y. Hashimoto, Biol. Pharm. Bull. 2008, 31, 976-980; b) S. Raja K. St George, L. Fan, C. Maring, K. McDaniel, D. DeGoey, J. Label. Compd. Radiopharm. 2010, 53, 472-474.

296 K.M. Giacomini, S.-M. Huang, D.J. Tweedie, L.Z. Benet, K.L.R Brouwer, X. Chu, A. Dahlin, R. Evers, V. Fischer, K.M. Hillgren, K.A Hoffmaster, T. Ishikawa, D. Keppler, R.B. Kim, C.A. Lee, M. Niemi, J.W. Polli, Y. Sugiyama, P.W. Swaan, J. A. Ware, S.H. Wright, S.W. Yee, M.J. Zamek-Gliszczynski, L. Zhang, Nat. Rev. Drug Disc. 2010, 9, 215236.

297 a) K. Maeno, A. Nakajima, G. Conseil, A. Rothnie, R.G. Deeley, S.P.C Cole, Drug Met. Dispos. 2009, 37, 1411-1420; b) E. Jigorel, M. Le Vee, C. Boursier-Neyret, M. Bertrand, O. Fardel, Drug. Met. Dispos. 2005 33, 1418-1422.

298 E. Smith, I. Collins, Future Med. Chem. 2015, 7(2), 159-183.

299 V.T.G. Chuang, M. Otagiri, Molecules 2013, 18, 13831-13859.

300 a) Y Xia, L. Peng Chem Rev 2013, 113, 7880-7929; b) Y Xia, K Sengupta, A. Maggiani, F. Qu, L. Peng, Org. Biomol. Chem. 2013, 11 5000-5005; c) T. Peng, X. Yuan, H.C. Hang, Curr. Opin. Chem. Biol. 2014, 21, 144-153.

301 a) U. Haedke, E.V. Küttler, O. Vosyka, Y. Yang, S.H.L. Verhelst, Curr. Opin. Chem. Biol. 2013, 17, 102-109; b) P.P. Geurink, L.M. Prely, G.A van der Marel, R. Bischoff, H.S. Overkleeft, Topics Curr. Chem. 2011 324, 85-113; c) A.M. Sadaghiani, S.H.L. Verhelst, M. Bogyo, Curr. Opin Chem. Biol. 2007, 11, 20-28; d) D. Robinette, N. Neamati, K.B. Tomer, C.H. Borchers, Expert Rev. Proteomics 2006, 3(4), 399-408.

a) J. Das, Chem. Rev. 2011, 111, 4405-4417; b) L. Dubinsky, B.P. Krom, M.M. Meijler, Bioorg. Med. Chem. 2012, 20, 554-570; c) M.S Panov, V.D. Voskresenska, M.N. Ryazantsev, A.N. Tarnovsky, R.M Wilson, J. Am. Chem. Soc. 2013, 135, 19167-19179; d) J. Liu, C. Liu, W. He, Curr. Org. Chem. 2013, 17, 564-579.

303 a) C.F. Filer, J. Radioanal. Nucl. Chem. 2009, 281, 521-530; b) D. Jakubczyk, G. Brenner-Weiss, S. Bräse, Eur. J. Org. Chem. 2014, 592 597 ; c) N.S. Kumar, M.P. Braun, A.G. Chaudhary, R.N. Young, J. Label. Compd Radiopharm 2011, 54, 43-50; d) Y. Ambroise, F. Pillon, C. Mioskowski, A. Valleix, B. Rousseau, Eur. J. Org. Chem. 2001, 39613964 .

304 a) D.J. Lapinsky, D.S. Johnson, Future Med. Chem. 2015, 7(16), 2143 2171; b) D.J. Lapinsky, Biorg. Med. Chem. 2012, 20, 6237-6247; c) A.L. MacKinnon, J. Taunton, Curr. Protoc. Chem. Biol. 2009, 1, 55-73

305 a) T. Tomohiro, S. Morimoto, T. Shima, J. Chiba, Y. Hatanaka, Angew. Chem. Int. Ed. 2014, 53, 13502-13505; b) S. Morimoto, T. Tomohiro, N Maruyama, Y. Hatanaka, Chem. Commun. 2013, 49, 1811-1813.

306 a) S.M. Lamos, C.J. Krusemark C.J. McGee, M. Scalf, L.M. Smith, P Belshaw, Angew. Chem. Int. Ed. 2006, 45, 4329-4333; b) Z. Song, W. Suang, Q. Zhang, Chem. Commun. 2012, 48, 3339-3341.

307 a) T. Bohnert, L.-S. Gan, J. Pharm. Sci. 2013, 102(9), 2953-2994; b) G.L. Trainor, Expert Opin. Drug Discov. 2007, 2(1), 51-64.

308 a) L.B. Nilsson, Bioanalysis 2013, 5(24), 3033-3050; b) F. Zhang, J. Xue, J. Shao, L. Jia, Drug Disc. Today 2012, 17(9-10), 475-485.

309 a) B. Buscher, S. Laakso, H. Mascher, K. Pusecker, M. Doig, L. Dillen W. Wagner-Redeker, T. Pfeifer, P. Delrat, P. Timmerman, Bioanalysis 2014, 6(5), 673-682; b) F.M. Musteata, Bioanalysis 2011, 3(15), 1753 1768.

310 a) A. Beattie, S. Madden, C. Lowrie, D. MacPherson, Bioanalysis 2015 , 7(5), 507- 511; b) M. Pellegatti, Expert. Opin. Drug Metab. 2014, 10(12), $1615-1620$; c) R.E. White, D.C. Evans, C.E.C. A Hop, D.J Moore, C. Prakash, S. Surapaneni, F.L.S. Tse, Xenobiotica 2013, 43(2), 219-225 d) R.S. Obach, A. N. Nedderman, D.A. Smith, Xenobiotica 2013, 43(2) 226-227; e) R.S. Obach, A.N. Nedderman, D.A. Smith, Chem. Res Toxicol. 2012, 25, 513-531; f) F.P. Guengerich, Chem. Res. Toxicol. 2012, 25, 511-512; g) D. Dalvie, Curr. Pharm Des. 2000, 6, 1009-1028.

311 B.K. Park, A. Boobis, S. Clarke, C. E. P. Goldring, D. Jones, J. G B.K. Park, A. Boobis, S. Clarke, C. E. P. Goldring, D. Jones, J. G.
Kenna, C. Lambert, H.G. Laverty, D.J. Naisbitt, S. Nelson, D. A. NicollGriffith, R.S. Obach, P. Routledge, D.A. Smith, D.J. Tweedie, N Vermeulen, D.P. Williams, I.D. Wilson, T.A. Baillie, Nat. Rev. Drug Disc. 2011, 10, 292-306.

312 a) J. Gan, T.W. Harper, M.M. Hsueh, Q. Qu, W.G. Humphreys, Chem. Res. Toxicol. 2005, 18, 896-903; b) Z. Yan, N. Maher, R. Torres, N Huebert, Anal. Chem. 2007, 79, 4206-4214; c) X. Ma, E.C. Chan Bioconjug. Chem. 2010, 21, 46-55.

313 T. Usui, M. Mise, T. Hashizume, M. Yabuki, S. Komuro, Drug Metab. Dispos. 2009, 37, 2383-2392.

314 a) S.H. Day, A. Mao, R. White, T. Schulz-Utermoehl, R. Miller, M.G Beconi, J. Pharmacol. Toxicol. Methods 2005, 52, 278-285; b) K. Samuel, W. Yin, R.A. Stearns, Y.S. Tang, A.G. Chaudhary, J.P. Jewell,
T. Lanza Jr., L.S. Lin, W. K. Hagmann D.C. Evans, S. Kumar, J. Mass Spectrom. 2003, 38, 211-221.

315 a) D.L. Nabb, B. Szostek, M.W. Himmelstein, M.P. Mawn, M.L. Gargas, L.M. Sweeney, J.C. Stadler, R.C. Buck, W.J. Fasano, Toxicol. Sci. 2007, 100(2), 333-344; b) A.N.R. Nedderman, M.E. Savage, K.L. White, D.K. Walker, J. Pharm. Biomed. Anal. 2004, 34, 607-617.

316 a) D. Dalvie, R. S. Obach, P. Kang, C. Prakash, C.M. Loi, S. Hurst, A N.R. Nedderman, L. Goulet, E. Smith, H.Z. Bu, Chem. Res. Toxicol. 2009, 22, 357-368; b) L. Xu, C. Woodward, S. Khan, C. Prakash, Drug. Metab. Dispos. 2012, 40, 680-693.

317 a) E.M. Isin, C.S. Elmore, G.N. Nilsson, R.A. Thompson, L. Weidolf Chem. Res. Toxicol. 2012, 25, 532-542; b) N. Penner, L. Xu, C Prakash, Chem. Res. Toxicol. 2012, 25, 513-531; c) D. Zhang, G. Luo, X. Ding, C. Lu, Acta Pharm. Sin. B 2012, 2(6), 549-561; d) a) P.H. Marathe, W.C. Shyu, W.G. Humphreys, Curr. Pharm. Des. 2004, 10, 2991-3008

318 a) E.G. Solon, Chem. Res. Toxicol. 2012, 25, 543-555; c) L. Wang, H. Hong, D. Zhang, Application of quantitative whole body autoradiography (QWBA) in drug discovery and development in ADME. in D. Zhang and S. Surapanemi, Eds. Enabling technologies in drug design and development. J Wiley \& Sons Publishers, Hoboken, NJ, 2012, 419-434; d) A.W. Harrell, C. Sychterz, M.Y. Ho, A. Weber, K. Valko, K. Negash, Pharma Res. Per. 2015, 3(5), e00173.

319 a) N. Penner, L.J. Klunk, C. Prakash, Biopharm. Drug Dispos. 2009, 30 185-203; b) S.J. Roffey, R.S. Obach, J.I. Gedge, D.A, Smith, Drug Metab. Rev. 2007, 39, 17-43; c) J.H. Beumer, J.H. Beijnen, J.H.M Schellens, Clin. Pharmacokin. 2006, 45(1), 33-58; d) J.G. Dain, J.M. Collins, W.T. Robinson, Pharm .Res. 1994, 11, 925

320 a) S.C. Alley, X. Zhang, N.M. Okeley, J. Pharmacol. Exp. Ther. 2009 330, 932-938; b) E. Herzog, S. Harris, C. Henson, Thromb. Res. 2014 $133,900-907$.

a) E.G. Solon, Expert Opin. Drug Discov. 2007, 2(4) 503-514; b) A McEwen, C. Henson, Bioanalysis 2015, 7(5), 557-568; b) M.J. Potchoiba, M.R. Nocerini, Drug. Metab. Dispos. 2004, 32, 1190-1198. a) U.B. Kompella, R.S. Kadam, V.H.L. Lee, Ther. Delivery 2010, 1(3) 435-456; b) W.E. Stumpf, J. Pharmacol. Toxicol. Methods 2005, 51, 2540; c) H. Chopade, D. Eigenberg, E. Solon, P. Strzemienski, J. Hostetler, T. McNamara, Vet. Ther. 2010, 11(4), 1-10.

a) N.A. Kulikova, D.P. Abroskin, G.A. Badun, M.G. Chernysheva, V.I Korobkov, A.S. Beer, E.A. Tsvetkova, S.V. Senik, O.I. Klein, I.V. Perminova, Sci. Rep. 2016, 6, 28869; b) G.A. Badun, Radiochim. Acta 2010, 98(3), 161-166. 